Utah State University

DigitalCommons@USU

$11-2-2018$

\title{
South American Leaf-Cutter Bees (Genus Megachile) of the Subgenera Rhyssomegachile and Zonomegachile, With Two New Subgenera (Hymenoptera: Megachilidae)
}

\author{
Víctor H. González \\ University of Kansas \\ Terry Griswold \\ USDA-ARS Pollinating Insects Research Unit \\ Michael S. Engel \\ American Museum of Natural History
}

Follow this and additional works at: https://digitalcommons.usu.edu/piru_pubs

Part of the Apiculture Commons, Biology Commons, Entomology Commons, and the Genetics and Genomics Commons

\section{Recommended Citation}

González, Víctor H., Griswold, Terry L., and Engel, Michael S. "South American Leaf-Cutter Bees (Genus Megachile) of the Subgenera Rhyssomegachile and Zonomegachile, With Two New Subgenera (Hymenoptera: Megachilidae)." Bulletin of the American Museum of Natural History, 2018, pp. 1-73.

This Bulletin is brought to you for free and open access by the Pollinating Insects Research Unit at DigitalCommons@USU. It has been accepted for inclusion in All PIRU Publications by an authorized administrator of DigitalCommons@USU. For more information, please contact digitalcommons@usu.edu.

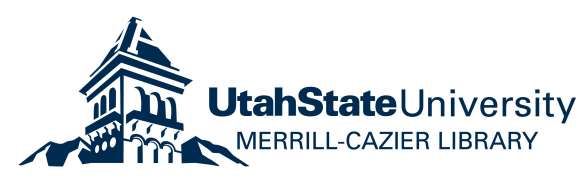


SOUTH AMERICAN LEAF-CUTTER BEES (GENUS MEGACHILE) OF THE SUBGENERA RHYSSOMEGACHILE AND ZONOMEGACHILE, WITH TWO NEW SUBGENERA (HYMENOPTERA: MEGACHILIDAE)

\section{VICTOR H. GONZALEZ, TERRY L. GRISWOLD,} AND MICHAEL S. ENGEL

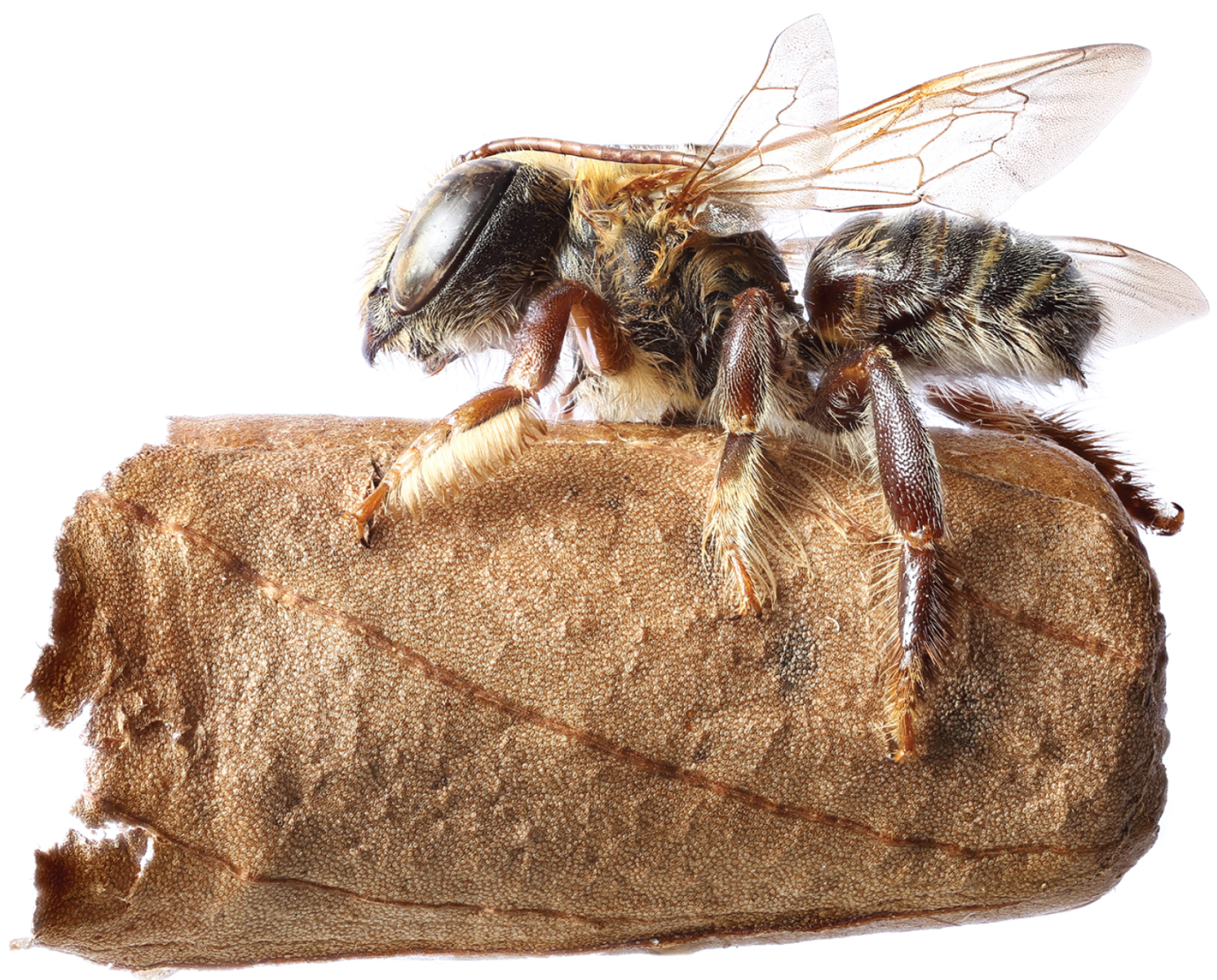

BULLETIN OF THE AMERICAN MUSEUM OF NATURAL HISTORY 


\title{
SOUTH AMERICAN LEAF-CUTTER BEES (GENUS MEGACHILE) OF THE SUBGENERA RHYSSOMEGACHILE AND ZONOMEGACHILE, WITH TWO NEW SUBGENERA (HYMENOPTERA: MEGACHILIDAE)
}

\author{
VICTOR H. GONZALEZ \\ Undergraduate Biology Program and Department of Ecology \& Evolutionary Biology, \\ University of Kansas, Lawrence, Kansas
}

TERRY GRISWOLD

USDA-ARS Pollinating Insects Research Unit,

Utah State University, Logan, Utah

MICHAEL S. ENGEL

Division of Invertebrate Zoology,

American Museum of Natural History, New York;

Division of Entomology, Natural History Museum, and

Department of Ecology \& Evolutionary Biology,

University of Kansas, Lawrence, Kansas

BULLETIN OF THE AMERICAN MUSEUM OF NATURAL HISTORY

Number 425, 73 pp., 34 figures, 2 tables

Issued November 2, 2018 


\section{CONTENTS}

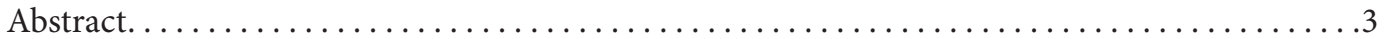

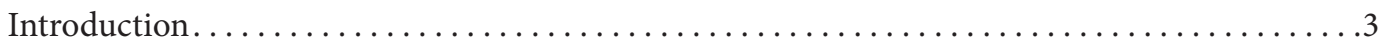

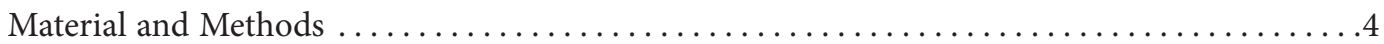

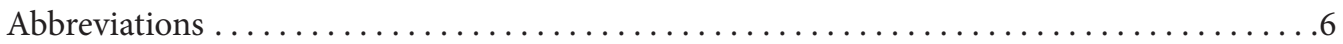

Phylogenetic Analysis . . . . . . . . . . . . . . . . . . . . . . . . . . . .

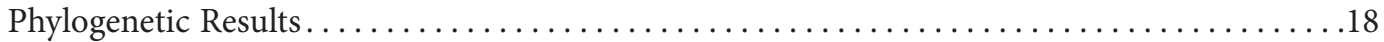

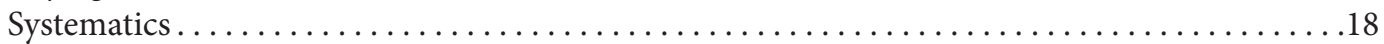

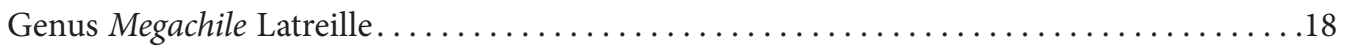

Subgenus Aporiochile Gonzalez and Engel, new subgenus .................. 18

Megachile (Aporiochile) tricosa Cockerell, resurrected status..................21

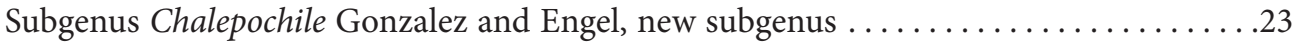

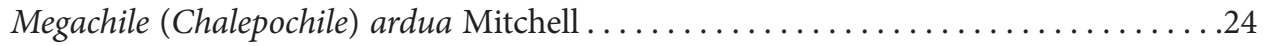

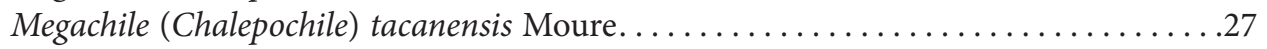

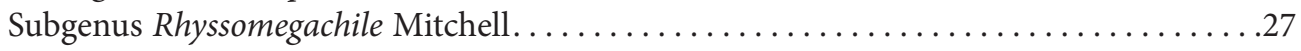

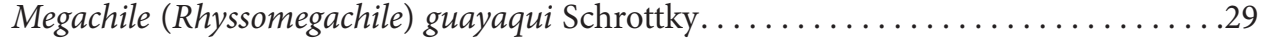

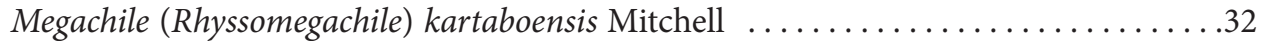

Megachile (Rhyssomegachile) simillima Smith ..........................

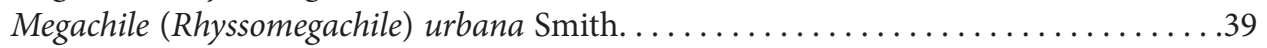

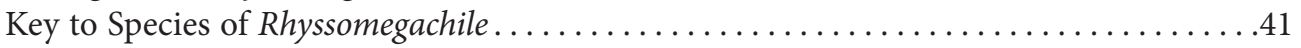

Subgenus Zonomegachile Mitchell ..................................42

Megachile (Zonomegachile) durantae, new species..................... 43

Megachile (Zonomegachile) gigas Schrottky.......................... 45

Megachile (Zonomegachile) kalina, new species .......................49

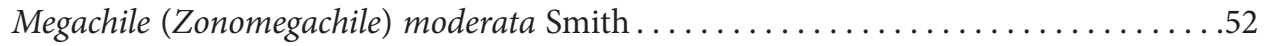

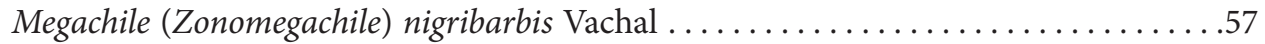

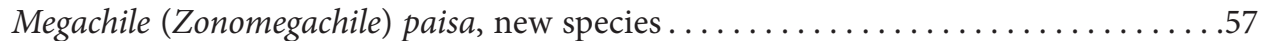

Megachile (Zonomegachile) reliqua Mitchell, resurrected status . . . . . . . . . . . 57

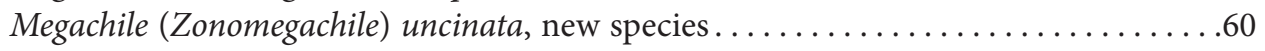

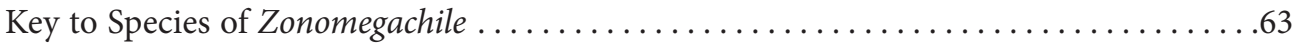

Key to Subgenera of Megachile s.l. of the Western Hemisphere.......................64

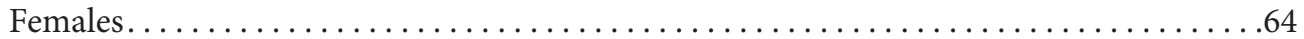

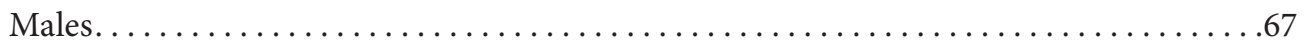

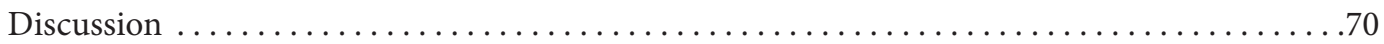

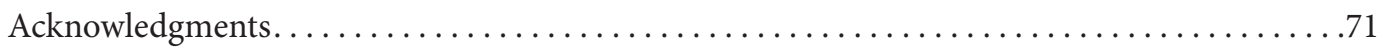

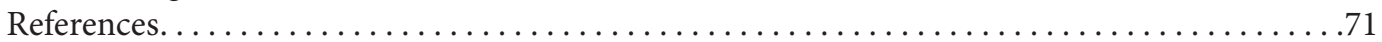




\begin{abstract}
Leaf-cutter bees (genus Megachile Latreille) are among the most common and diverse group of bees. However, the identity and taxonomic placement of many species are problematic and species identification is often difficult. Some species are known only from a single specimen or from one of the sexes, and identification keys are not available for many groups. We address these taxonomic issues for the subgenera Rhyssomegachile Mitchell and Zonomegachile Mitchell, two poorly known South American lineages of leaf-cutter bees. We provide comparative diagnoses, redescriptions, illustrated identification keys, new geographical records, and designate needed neotypes for Megachile cara Mitchell, M. gigas Schrottky, M. guayaqui Schrottky, M. reliqua Mitchell, M. sanctipauli Schrottky, M. stabilis Mitchell, and M. turbulenta Mitchell. We resurrect M. tricosa Cockerell from synonymy with $M$. urbana Smith and synonymize $M$. turbulenta under $M$. tricosa. We recognize four species in Rhyssomegachile and eight species in Zonomegachile. In the latter subgenus, we revalidate $M$. reliqua from synonymy with $M$. moderata and propose the following four new species: Megachile kalina, new species, from French Guiana; M. durantae, new species, from Rondônia, Brazil; M. paisa, new species, from Antioquia, Colombia; and M. uncinata, new species, from Catamarca, Argentina. We confirm sex associations in Zonomegachile and describe its nest for the first time. Megachile tricosa, M. ardua Mitchell, and M. tacanensis Moure, currently assigned to Rhyssomegachile, exhibit morphological features that do not fit any of the known subgenera. Thus, we use a cladistic analysis to explore their phylogenetic relationships and establish two new subgenera for these species: Aporiochile Gonzalez and Engel, new subgenus, for M. tricosa and Chalepochile Gonzalez and Engel, new subgenus, for the remaining two species. We provide an updated key to the subgenera of Megachile s.l. of the Western Hemisphere.
\end{abstract}

\section{INTRODUCTION}

Leaf-cutter bees (a subset of taxa within the diverse genus Megachile Latreille s.l.) are among the most distinctive and frequently encountered species groups of wild bees. The group is cosmopolitan in distribution with several hundred nominal species. Those species colloquially known as leaf-cutter bees (groups 1 and 3 of Michener, 2007), are so called owing to their characteristic behavior of cutting semicircular swaths out of leaves and using these plant fragments to construct and line their brood chambers, which can be found in the hollows of stems or wood, subterranean burrows, or even within small cavities of human-made objects. Such distinctive cuts in leaves can be found as far back as the Paleocene (Wedmann et al., 2009). Although it is seemingly easy to recognize a leaf-cutter bee, the classification of the group has been challenging at both the specific as well as the supraspecific levels. The genus Megachile has undergone numerous alterations in circumscription during the last 60 years of systematic inquiry, during which time the classification has varied from segregation into numerous genera (e.g., Michener, 1962, 1965; Mitchell, 1980), to a retrograde system uniting all leaf-cutting species with a grade of principally resin- or mud-collecting taxa into a single, monolithic genus with a profusion of subgenera (e.g., Michener, 2007). Several attempts have been made to further refine the subgeneric system employed (e.g., Engel, 1999; Baker and Engel, 2006; Engel and Baker, 2006; Raw, 2006; Durante and Cabrera, 2009; Gonzalez et al., 2010; Engel and Gonzalez, 2011; Gonzalez and Engel, 2012; Gonzalez, 2013; Praz, 2017), and recent phylogenetic efforts have similarly endeavored to bring some clarity to the relationships and natural groups within this diverse complex (e.g., Gonzalez, 2008; Trunz et al., 2016). Revisionary treatments of particular subgenera have been few (refer to Michener, 2007), and the means to identify most species within the vast Neotropical fauna remains a significant hindrance to biological and ecological research. 
The purpose of the present paper is to clarify the taxonomic status of the species currently assigned to the subgenera Rhyssomegachile Mitchell and Zonomegachile Mitchell. Both subgenera occur in South America and each consists of a small number of species poorly represented in collections. To date, seven species have been placed in Rhyssomegachile while only three have been recognized for Zonomegachile (Moure et al., 2007). Most of them are known only either from the type specimen or from one of the sexes alone (table 1), identification keys to species are entirely lacking for both subgenera, and some species cannot correctly be identified at the subgeneric level with the existing keys. For example, in the key for males to the subgenera of Megachile s.l. of Michener (2007), Megachile ardua Mitchell, M. simillima Smith, and M. tacanensis Moure run to Austromegachile Mitchell instead of Rhyssomegachile, the subgenus to which they are currently assigned, nor do they agree with, or belong to, the former. Likewise, in the key for males to the subgenera of Megachile s.l. of Brazil (Silveira et al., 2002), M. ardua and M. tacanensis also run to Austromegachile while $M$. simillima correctly keys out to Rhyssomegachile. Thus, existing resources for recognizing even the proper subgenus, let alone species, are insufficient.

In addition, the whereabouts of the holotype of some species is unknown and sex associations are questionable (see individual species accounts, below). Resolving the latter issue is particularly important in Zonomegachile because the male is morphologically similar to that of some species of the subgenus Chrysosarus Mitchell, while the female, unlike any species of Chrysosarus, has distinct cutting edges, or interdental laminae (sensu Pasteels, 1965: 2; see Methods, below), in the second and third mandibular interspaces. Michener (2007) was the first in questioning the sex association in Zonomegachile and he did not include this subgenus in his keys because of the lack of material. Such a superficial resemblance between the males of both subgenera and the presumed incorrect association of sexes led one of us (Gonzalez, 2013) to synonymize Zonomegachile under Chrys- osarus. However, while sorting undetermined material of Megachile s.l. at the Snow Entomological Collection, Division of Entomology, University of Kansas Natural History Museum, Lawrence, Kansas, we recently found several specimens of both sexes of Zonomegachile that were reared from the same nest. These specimens, which turned out to be an undescribed species, confirm the sex association of Zonomegachile and support the uniqueness of this group.

Herein we circumscribe Rhyssomegachile and Zonomegachile, provide comparative diagnoses, specific redescriptions, fully illustrated identification keys, new geographical records, and designate primary types to stabilize the nomenclature of some species. We describe and illustrate four new species of Zonomegachile and provide comments on the nest of M. kalina, n. sp. In addition, we establish two new subgenera and, in order to understand their phylogenetic placement, we undertook a cladistic analysis based on adult external morphological characters. Finally, we provide an updated key to the subgenera of Megachile s.l. occurring in the Western Hemisphere. We hope this work encourages future studies on the biology and systematics of these bees.

\section{MATERIAL AND METHODS}

Morphological terminology follows that of Engel (2001) and Michener (2007), except for interdental laminae and torulus; herein we use instead the former for cutting edges and the latter for antennal socket. The term cutting edges has been widely used in the taxonomic literature of Megachile s.l. (Michener, 1962, 2007) to describe the laminae between the teeth of the female mandible (figs. 1, 2, 3C-F), which are associated with leaf-cutter behavior. However, these terms are functionally and structurally ambiguous because they imply that these are the only structures used in cutting leaves and do not provide information on their shape or location in the mandible. The absence of cutting edges in some species of Megachile s.l. that also cut leaves (e.g., subgenus Chrysosarus, fig. 3A, 


\section{TABLE 1}

\section{Summary of Taxonomic Changes}

Current (Moure et al., 2007) and new species names with newly proposed changes in Rhyssomegachile Mitchell and Zonomegachile Mitchell, including the two new subgenera described herein. Indented and regular typeface names are junior subjective synonyms. Currently known sexes indicated in square brackets.

\begin{tabular}{|c|c|c|}
\hline Previous Work & \multicolumn{2}{|c|}{ Current Work } \\
\hline Subgenus Rhyssomegachile Mitchell & SuBgENUS RHYSSOMEGACHILE MiTCHELL & $\begin{array}{l}\text { SubGENuS CHALEPOCHILE } \\
\text { GONZALEZ \& ENGEL }\end{array}$ \\
\hline M. ardua Mitchell, 1930 & & M. ardua Mitchell [ $\widehat{o}]$ \\
\hline M. guayaqui Schrottky, 1913 & \multicolumn{2}{|l|}{ M. guayaqui Schrottky [q] } \\
\hline M. kartaboensis Mitchell, 1930 & \multicolumn{2}{|l|}{ M. kartaboensis Mitchell [ $q$ ] } \\
\hline M. simillima Smith, 1853 & \multicolumn{2}{|l|}{ 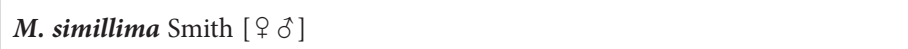 } \\
\hline M. cara Mitchell, 1930 & \multicolumn{2}{|l|}{$=$ M. cara Mitchell } \\
\hline M. stabilis Mitchell, 1930 & \multicolumn{2}{|l|}{$=$ M. stabilis Mitchell } \\
\hline M. tacanensis Moure, 1948 & & M. tacanensis Moure $[\widehat{ठ}]$ \\
\hline \multicolumn{3}{|l|}{ M. turbulenta Mitchell, 1930} \\
\hline M. urbana Smith, 1879 & M. urbana Smith [ $q$ ] & $\begin{array}{l}\text { Subgenus APORIOCHILE GONZALEZ \& } \\
\text { ENGEL }\end{array}$ \\
\hline \multirow[t]{2}{*}{ M. tricosa Cockerell, 1927} & & M. tricosa Cockerell [ $₫]$ \\
\hline & & $=$ M. turbulenta Mitchell, n. syn. [ $\widehat{0}]$ \\
\hline Subgenus Zonomegachile Mitchell & \multirow{2}{*}{\multicolumn{2}{|c|}{$\begin{array}{l}\text { Subgenus Zonomegachile Mitchell } \\
\left.\text { M. durantae, n. sp. [ }{ }^{+}\right]\end{array}$}} \\
\hline & & \\
\hline M. gigas Schrottky, 1908 & \multicolumn{2}{|l|}{ 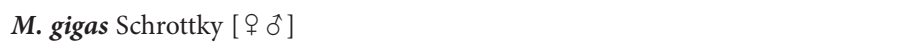 } \\
\hline M. sanctipauli Schrottky, 1913 & \multicolumn{2}{|l|}{$=M$. sanctipauli Schrottky } \\
\hline M. aequalis Mitchell, 1930 & \multicolumn{2}{|l|}{$=M$. aequalis Mitchell } \\
\hline & \multicolumn{2}{|l|}{ M. kalina, n. sp. [ $\stackrel{\uparrow}{\dagger}]$} \\
\hline M. moderata Smith, 1879 & \multicolumn{2}{|l|}{ 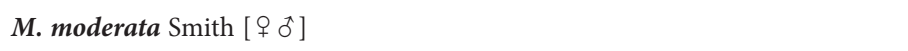 } \\
\hline M. reliqua Mitchell, 1930 & \multicolumn{2}{|l|}{ M. reliqua Mitchell [ $q$ ] } \\
\hline M. nigribarbis Vachal, 1909 & \multicolumn{2}{|l|}{ M. nigribarbis Vachal [ } \\
\hline & \multicolumn{2}{|l|}{ M. paisa, n. sp. [] } \\
\hline & \multicolumn{2}{|l|}{ M. uncinosa, n. sp. [ठิ] } \\
\hline
\end{tabular}

B) clearly indicates (e.g., Zillikens and Steiner, 2004; Torretta et al., 2014) that these are not the only mandibular structures involved in this behavior. For example, the upper and lower margins of each tooth are sometimes thin and sharp, and they might function as razors even when cutting edges are present. Thus, as initially proposed by Pasteels (1965), the term interdental laminae seems to be more appropriate than cutting edges to describe these laminae between the teeth. We use torulus because it is in broader application across Hymenoptera.

To describe and measure body features, we used an ocular micrometer on a Leica S6E stereomicroscope. All measurements follow Michener (2007), except forewing length, which we measured from the posterior margin of the tegula to the wing tip. Species descriptions emphasize structural characters that are reliable for species identification. We prepared photomi- 
crographs using a Canon 7D digital camera attached to an Infinity K-2 long-distance microscope lens, and assembled series of images at different focal depths with the Zerene Stacker ${ }^{\mathrm{TM}}$ software package. Descriptions are presented in the context of providing modern circumscriptions and images for bees at the specific level, thereby improving species hypotheses (Engel, 2011; Gonzalez et al., 2013).

To map the distribution of each species, we used the geographical coordinates associated with specimen labels and, for records that did not have exact geographical information, we used Google Earth (Google, Mountain View, California) to acquire their coordinates. We assembled 57 occurrence records for the included species and generated maps using SimpleMappr (Shorthouse, 2010). We reproduced label data as appearing on the label(s) attached to each specimen. We separated information on different labels by a single slash (/) and indicated annotations to clarify information in square brackets. To avoid repetition of label data, we used ut supra ("as above") to indicate the same information on the preceding label. The Latin term idem is more broadly used to replace the name of an author in academic texts, although it has also been used in taxonomic works to avoid repetition of label data.

In the couplet numbers of identification keys we have referenced the original directing couplet in parentheses, thereby permitting a user to more easily work backwards when needed. For example, a couplet number of 16(5) means that one half of couplet 5 originally directed the user to couplet 16 .

The primary types associated with several of the species-group names involved herein are missing and are newly replaced by neotypes. The holotypes of M. guayaqui Schrottky, M. gigas Schrottky, and M. sanctipauli Schrottky were supposedly deposited in the Museu de Zoologia da Universidade de São Paulo but are known to be missing (Rasmussen et al., 2009). Similarly, the holotypes of $M$. cara Mitchell, M. reliqua Mitchell, M. stabilis Mitchell, and M. turbulenta
Mitchell could not be traced and were presumed lost during the World War II. For these four species, Theodore B. Mitchell (1890-1983) had received the type series from Reinhold Meyer (1892-1944). ${ }^{1}$ Mitchell (1930) described the species and retained paratypes for each within his collection (found today in NCSU), and returned the holotypes to Meyer. Meyer's collection of Diptera is today in the Hessichen Landesmuseum Darmstadt (Koch, 1999), but aside from a small sample of wasps his collection of Hymenoptera (including the bees) did not survive World War II (Tischendorf et al., 2009). Aside from our own hunt through various pertinent collections, the late Padre Moure (1912-2010) made extensive surveys of American and European institutions for types of neotropical bees and was similarly unable to locate additional material from the type series of these taxa (Moure et al., 2007). Because many of the species involved may be easily confused with one another, neotypes are designated in order to stabilize the application of each name. Refer to the individual species accounts for further details.

\section{Abbreviations}

We use the following institutional acronyms for repositories holding specimens:

AMNH American Museum of Natural History, New York (J.G. Rozen, Jr.)

ANSP Academy of Natural Sciences, Philadelphia, Pennsylvania (D. Otte, J. Weintraub)

BBSL USDA-ARS, Pollinating Insects Research Unit, Utah State University, Logan, Utah (T.L. Griswold, H. Ikerd)

\footnotetext{
${ }^{1}$ Reinhold Meyer (1892-1944) was a talented entomologist trained in Jena during the early years of World War I whose primary interest among the bees was the cleptoparasitic genus Sphecodes Latreille (Halictinae). Meyer was a plant chemist at the Institut für Pflanzenkrankheiten der Staatlischen landwirtschaftlichen Versuchs- und Forschungsanstalten Landsberg an der Warthe (at the time part of Germany, today Gorzów Wielkopolski in western Poland), but by 1924 was employed in the plant-protection labs at the headquarters of Merck Industries in Darmstadt, Germany (Hirsch, 1928). Meyer died during an Allied air raid on Darmstadt in 1944.
} 
BMNH Natural History Museum, London, United Kingdom (D. Notton)

DZUP Departamento de Zoologia, Universidade Federal do Paraná, Curitiba, Paraná, Brazil (material not available but acronym is referenced in relation to type deposition)

MCZ Museum of Comparative Zoology, Harvard University, Cambridge, Massachusetts (P.D. Perkins, R. Hawkins)

MNHN Museum National d'Histoire Naturelle, Paris, France (material not available but acronym is referenced in relation to type deposition)

NCSU North Carolina State University Insect Museum, Raleigh, North Carolina (B. Blinn)

SEMC Division of Entomology (Snow Entomological Collection), University of Kansas Natural History Museum, Lawrence, Kansas (M.S. Engel, Z.H. Falin)

USNM Department of Entomology, National Museum of Natural History (United States National Museum), Smithsonian Institution, Washington D.C. (S. Brady, B. Harris)

The following anatomical abbreviations are used:

F antennal flagellomere

Mt mandibular tooth

OD median ocellar diameter

PW puncture width

S metasomal sternum

$\mathrm{T}$ metasomal tergum

\section{Phylogenetic Analysis}

To explore the relationships of Megachile tricosa Cockerell, M. ardua, and M. tacanensis with Rhyssomegachile, we coded and analyzed a data matrix from adult external morphology. We coded 58 characters for 21 species that included all species of Rhyssomegachile as well as representatives of the following leaf-cutting subgen- era: Acentron Mitchell, Austromegachile Mitchell, Chrysosarus Mitchell, Cressoniella Mitchell, Neochelynia Schrottky, Ptilosaroides Mitchell, Ptilosarus Mitchell, Trichurochile Mitchell, Tylomegachile Moure, and Zonomegachile Mitchell. We chose one or two species of each subgenus (table 2) because they represent closely and distantly related taxa to Rhyssomegachile. All subgenera listed above, except for Acentron, Chrysosarus, Tylomegachile, and Zonomegachile, were included by Mitchell (1980) in the same group (as the genus Cressoniella in his system), a relationship partially supported by available cladistics analyses (e.g., Gonzalez, 2008). We used M. (Acentron) albitarsis Cresson to root the tree because this subgenus appears to be the most distant relative among the selected taxa. We constructed the data matrix in WinClada (Nixon, 1999), and submitted from there for parsimony analyses in TNT (Goloboff et al., 2003a, 2008). We treated all characters as nonadditive and equally weighted. The majority of characters used in the analysis are the same or modified from those of Gonzalez (2008), with the exception of characters $4,9,22$, and 47 , which are herein documented for the first time. We searched for trees in TNT by implementing sectorial searches with tree drifting (TD) and tree fusing (TF), and ratchet runs with TD and TF. We used the following search: keep a maximum of 10,000 random trees, 500 random addition sequences, and 1000 ratchet iterations, including 100 cycles of TD and 100 rounds of TF per iteration. We estimated branch robustness using standard bootstrap (sample with replacement) and absolute Bremer support in TNT, and plotted the values on the strict consensus topology obtained from the final TNT parsimony run. We used 10,000 bootstrap replicates under a heuristic tree search that consisted of 10,000 replicates of Wagner trees with random addition sequences, followed by Tree Bisection Reconnection (TBR) branch swapping (saving 10 trees per replicate). Resulting values per node represent frequency differences GC for Group present/Contradicted (Goloboff et al., 
TABLE 2

Data Matrix for Cladistic Analysis

Abbreviations: -, inapplicable; ?, unknown character state.

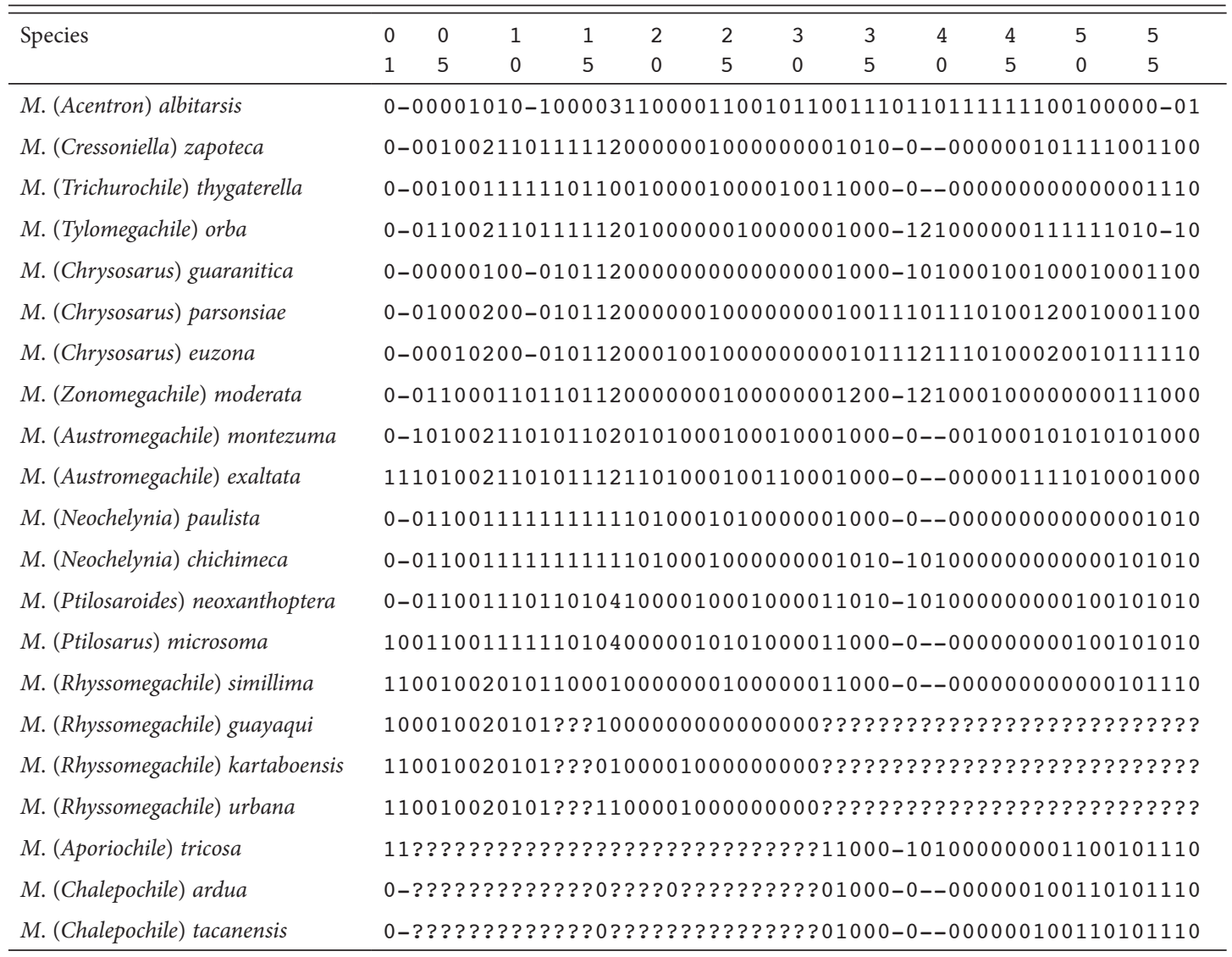

2003b). We calculated Bremer support by withholding 10,000 suboptimal trees up to 10 steps longer than the most parsimonious trees under a traditional search (10,000 replicates of Wagner trees, followed by TBR, saving 10 trees per replicate). We visualized cladograms in WinClada, collapsing unsupported nodes and using DELTRAN (slow) for character optimization; the latter favors, when the choices are equally parsimonious, repeated origins of characters over reversals. The abbreviations L, CI, and RI are used for tree length, consistency index, and retention index, respectively, when reporting descriptive statistics of tree topologies.

The following are the descriptions of the characters used in the cladistics analysis:

\section{Female CHARACters}

1. Preoccipital carina: $0=$ absent; $1=$ present

2. Preoccipital carina: $0=$ continuous, present on gena and dorsal edge of head behind vertex; 1 = discontinuous, present on gena only.

3. Disc of clypeus: 0 = flat or convex, not elevated; $1=$ elevated with flat median section.

4. Mandible with upper root of outer ridge: 0 = absent (fig. 1A); 1 = present, extending toward acetabulum and joining acetabular carina (fig. 2A).

5. Pubescence on apex of acetabular mandibular groove: $0=$ not forming distinct 
tuft or brush of long golden setae; $1=$ forming a distinct tuft or brush of long golden setae (apical acetabular tuft, figs. 1A, 2A).

6. Mandible with outer premarginal impressed fimbria: 0 = reduced or absent; $1=$ present, distinct (Michener and Fraser, 1978: fig. 29).

7. First mandibular tooth $\left(\mathrm{Mt}_{1}\right): 0=$ at most $1.4 \times$ wider, at base, than second (figs. $1 \mathrm{~A}$, $2 \mathrm{~A}, \mathrm{E}) ; 1=\geq 1.5 \times$ wider, at base, than second (fig. 3C).

8. Shape of upper mandibular tooth $\left(\mathrm{Mt}_{4}\right): 0$ $=$ acute or right angular (fig. $2 \mathrm{~A}$ ); $1=$ rounded or truncate, not incised; $2=$ rounded or truncate, incised (fig. 1A).

9. Inner surface of mandible preapically: $0=$ with a distinct carina running parallel to the mandibular margin, usually posterior to the bases of teeth and not apically extended into a lamina; the surface formed between this carina and the mandibular margin somewhat perpendicular (fig. 3B); 1 = with a distinct lamina projecting beyond bases of upper teeth (figs. 1, 2, 3C-F).

10. Mandible with interdental lamina in second interspace: $0=$ absent (fig. 3A, C); $1=$ present (figs. 1A, 2A).

11. Type of interdental lamina in second interspace: $0=$ incomplete, not filling interspace (fig. 1A); 1 = complete, filling interspace (figs. 2A, 3E).

12. Mandible with interdental lamina in third interspace: $0=$ absent (fig. 3A); $1=$ present (figs. 2A, 3C, E).

13. Inner surface of mandible with a distinct secondary fimbria: $0=$ absent; 1 = present (figs. 1C, 2C).

14. Length of second maxillary palpomere: $0=$ short, $\leq 1.6 \times$ longer than broad; $1=$ long, $\geq 2.0 \times$ longer than broad.

15. Length of third maxillary palpomere: $0=$ short, $\leq 2.6 \times$ longer than broad; $1=$ long, $\geq 3.0 \times$ longer than broad.
16. Punctures of disc of mesoscutum: $0=$ contiguous (fig. 4A); 1 = spaced, not contiguous (fig. 4B, C).

17. Pubescence of disc of mesoscutum: $0=$ consisting only of long setae ( $\geq 3.0-4.0 \times$ $\mathrm{OD})$, integument barely visible; $1=$ consisting only of exceedingly short setae $(\leq 0.5 \times \mathrm{OD})$, integument sparsely covered to almost bare; 2 = consisting only of short setae (1.5-2.0× OD), integument visible or partially obscured among setae; 3 = consisting of two types of setae, minute, yellowish, appressed setae, and erect longer setae $(2.0 \times \mathrm{OD}) ; 4=$ consisting of semierect or appressed yellowish tomentum uniformly covering the integument.

18. Mesoscutal-mesoscutellar sulcus with white fascia: $0=$ absent; $1=$ present.

19. Mesoscutellum: 0 = flat or convex, forming relatively uninterrupted surface with metanotum in profile, thus without a distinct posterior surface; 1 = elevated from metanotum, with a distinct posterior surface.

20. Metanotum: 0 = entirely or partially hidden, as seen from above, by mesoscutellum; 1 = fully exposed, not hidden by mesoscutellum.

21. Color of legs: $0=$ dark brown to black, concolorous with remaining areas of mesosoma; 1 = reddish or orange, contrasting with dark brown to black mesosoma.

22. Outer surface of probasitarsus with corkscrew setae: $0=$ absent (fig. $4 \mathrm{~F}$ ); $1=$ present (fig. 4D, E).

23. Forewing coloration: $0=$ entirely hyaline, yellowish, or dusky; 1 = yellowish wing base with dusky costal margin.

24. T2 and T3 with deep postgradular groove: $0=$ absent; 1 = present.

25. T2 and T3 with fasciate marginal zones: 0 $=$ absent; $1=$ present.

26. T3 and T4 with well-marked premarginal line: $0=$ absent; 1 = present. 
A

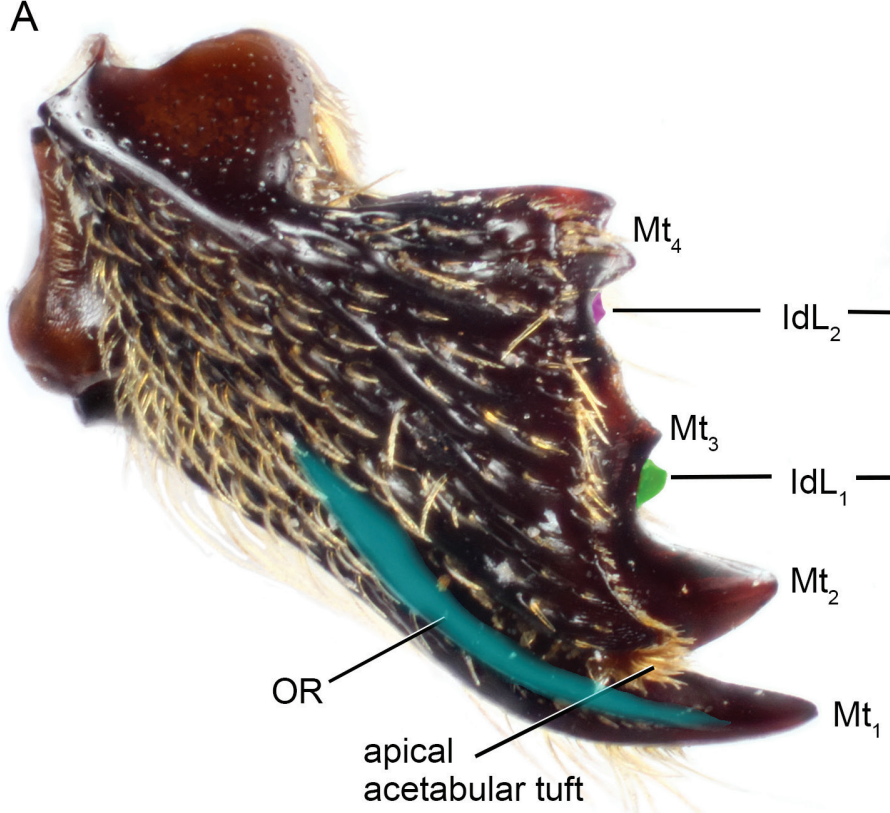

B

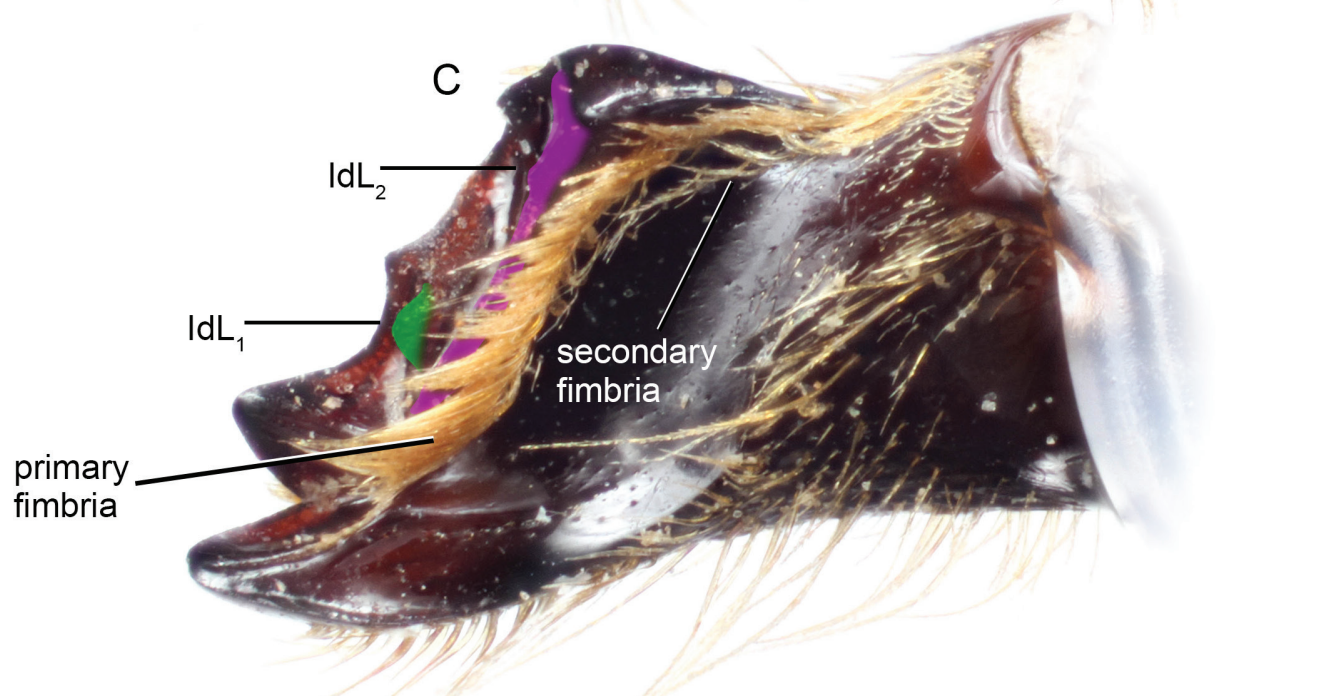

FIGURE 1. Female mandible of Megachile (Rhyssomegachile) simillima Smith. A. Outer view. B. Anterior view. C. Inner view. Abbreviations: $\mathbf{M t}=$ mandibular tooth; $\mathbf{I d L}=$ interdental lamina, $\mathbf{O R}=$ outer ridge (Colombia: Amazonas, SEMC 1184307). 

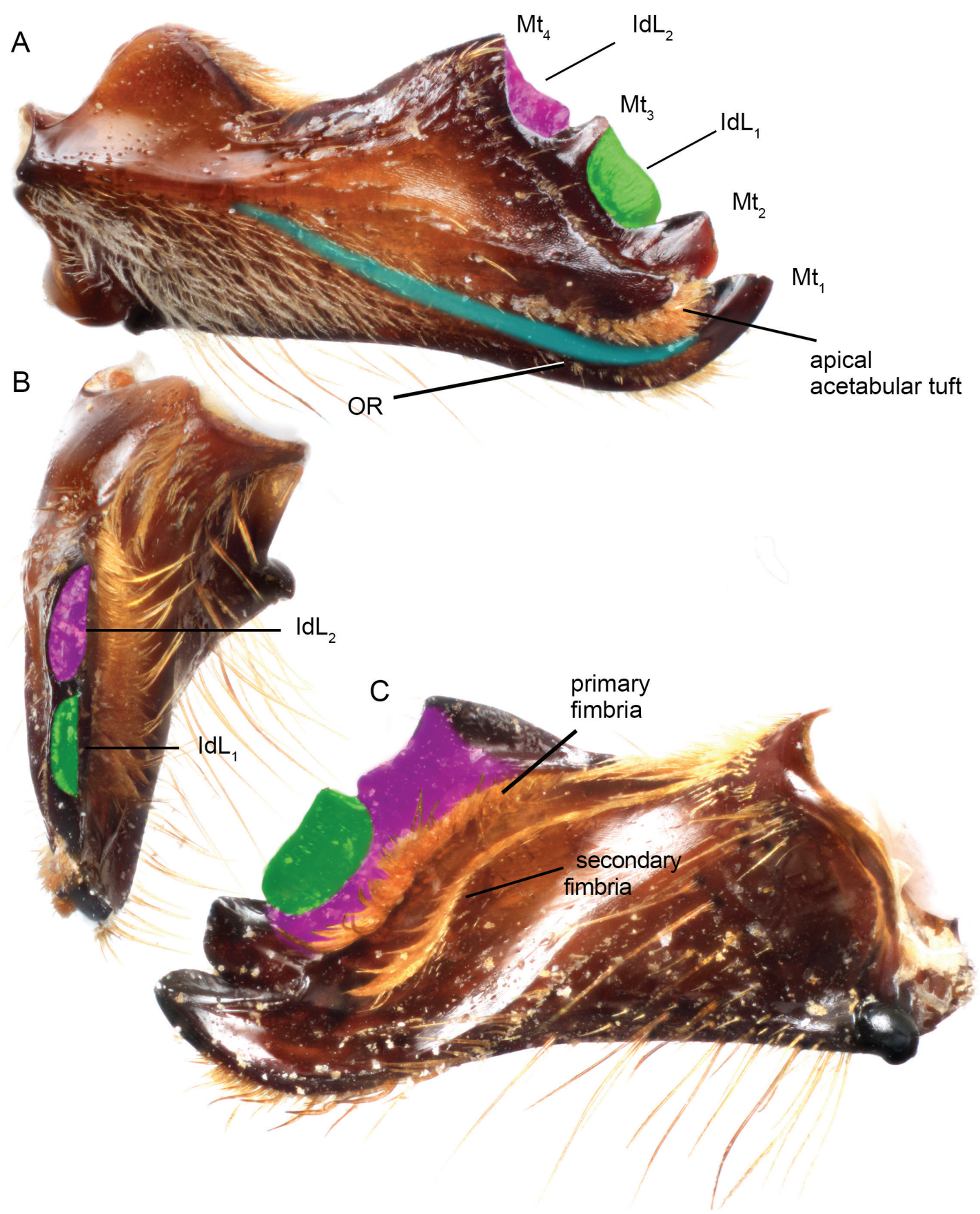

FIGURE 2. Female mandible of Megachile (Zonomegachile) kalina Gonzalez, Griswold, and Engel, new species. A. Outer view. B. Anterior view. C. Inner view. Abbreviations: $\mathbf{M t}=$ mandibular tooth; $\mathbf{I d L}=$ interdental lamina, OR = outer ridge (paratype, French Guiana, SEMC 1204559). 


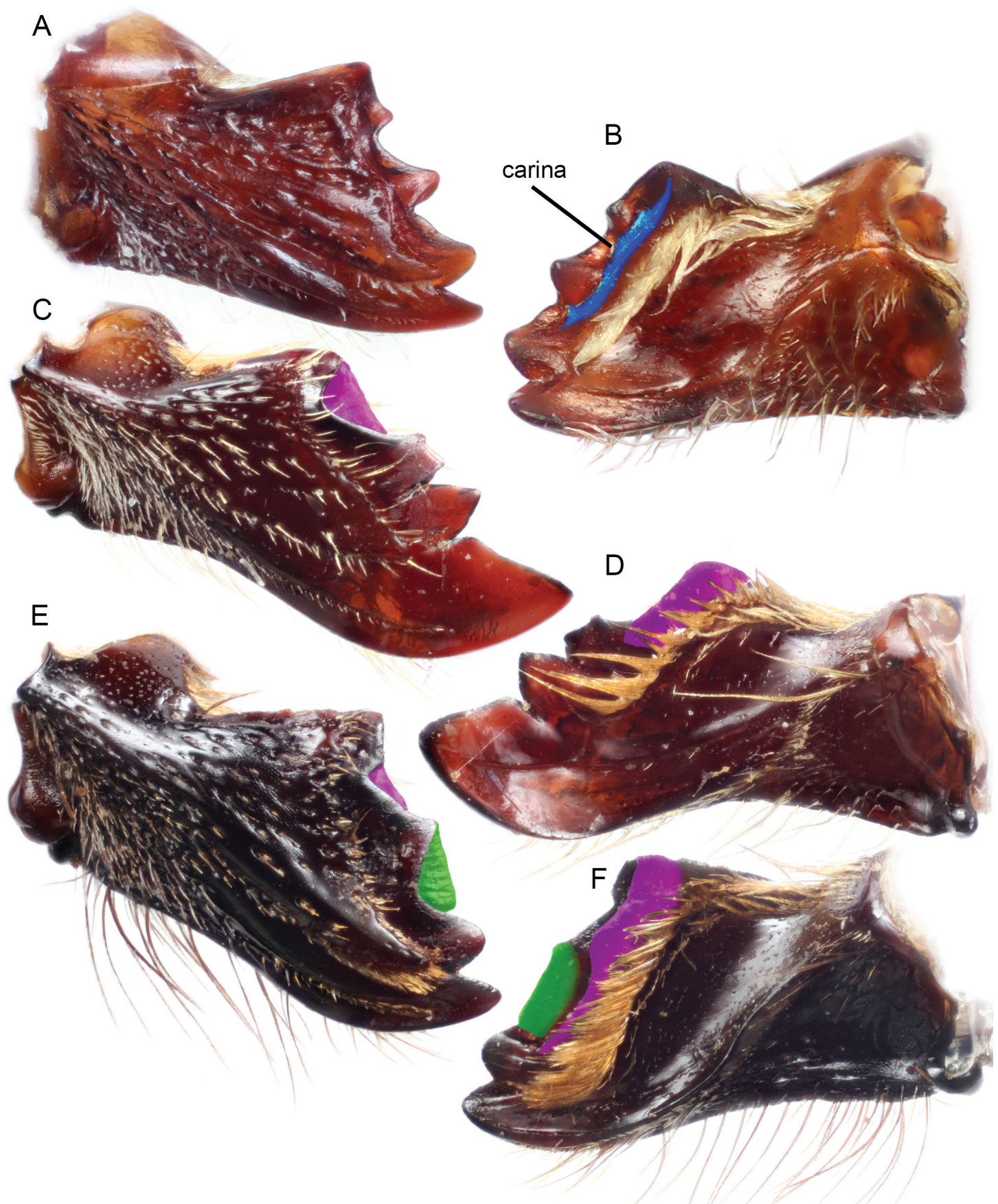

FIGURE 3. Female mandibles of leaf-cutter bees in outer (left figures) and inner views (right figures). Interdental laminae highlighted in green and pink, a distinct carina in blue. A, B. Megachile (Chrysosarus) parsonsiae Schrottky (Brazil, São Paulo, Rio Claro, SEMC 1178901). C, D. M. (Acentron) albitarsis Cresson (Costa Rica, San José, SEMC 1177780). E, F. M. (Moureapis) maculata Smith (Brazil, Santa Catarina, Nova Teutônia, SEMC 1182023). 

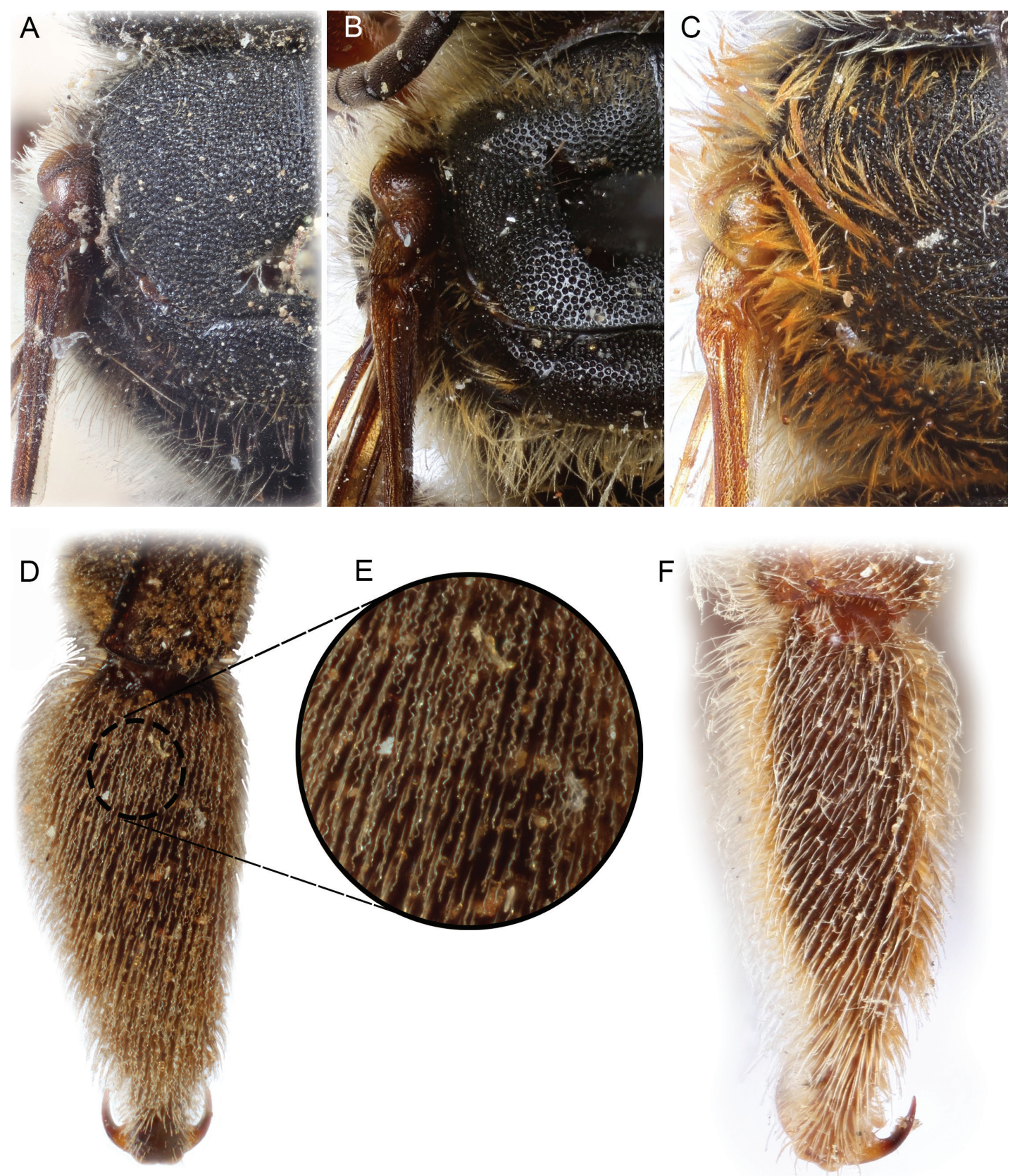

FIGURE 4. Some morphological features used in the phylogenetic analysis. A-C. Punctation of mesoscutum. D-F. Pubescence of outer surface of female protarsi. A. Megachile (Rhyssomegachile) simillima Smith (female holotype). B. M. (Aporiochile) tricosa Cockerell (male holotype). C. M. (Rhyssomegachile) guayaqui Schrottky (female neotype). D, E. M. (Rhyssomegachile) kartaboensis Mitchell (female holotype). F. M. (Zonomegachile) moderata Smith (female holotype). 
27. Pubescence of T5: 0 = black, pale or yellowish, as on preceding terga; $1=$ orange, yellowish, or pale as on T6, contrasting with that of T1-T4.

28. T6 with erect setae on disc: $0=$ present; 1 $=$ absent.

29. Apical white fasciae under scopa of S2 and S3: 0 = absent; 1 = present.

30. Setose area of S6: $0=$ uniformly covered with setae or nearly so (fig. $5 \mathrm{~A}$ ); 1 = bare or nearly so (fig. 5B).

31. S6 with smooth, bare rim behind apical fringe of branched setae: $0=$ absent; $1=$ present

\section{MALE CHARACTERS}

32. Pubescence of clypeus: $0=$ dense throughout, integument not visible among setae (fig. 5C); 1 = basal half with sparse setae (integument visible) or mostly bare, distal half densely covered by setae (integument not visible) (fig. 5D).

33. Length of F1: $0=$ about as long as F2; $1=$ shorter than F2.

34. Hypostomal area: $0=$ unmodified; $1=$ modified, slightly depressed, strongly concave (fig. $5 \mathrm{E}$ ); 2 = strongly protuberant (fig. 5F).

35. Mandibular teeth: $0=$ three; $1=$ four.

36. Inferior border of mandible: $0=$ unmodified; 1 = modified, with a tooth, process, or projection (fig. $5 \mathrm{E}, \mathrm{G}$ ).

37. Inferior process of mandible: $0=$ slender, posteriorly directed (fig. 5E, G); 1 = with a small angle midapically.

38. Procoxal spine: $0=$ absent; $1=$ present

39. Length of procoxal spine: $0=$ short $(\leq 1.5 \times$ $\mathrm{OD})$, pointed or somewhat parallel-sided; $1=$ long $(\geq 2.0 \times \mathrm{OD})$, not parallel-sided; 2 $=$ long $(\geq 2.0 \times \mathrm{OD})$, tapering apically, parallel sided or nearly so.

40. Pubescence on ventral surface of procoxal spine: $0=$ very sparse to nearly asetose, integument clearly visible; 1 = densely covered with branched setae, integument barely visible among setae.
41. Disc of procoxa: $0=$ uniformly covered with branched setae, integument barely visible among setae; 1 = asetose or nearly so, integument clearly visible.

42. Procoxa with a tuft of stiff ferruginous setae: $0=$ absent; $1=$ present.

43. Protibia: $0=$ unmodified, not enlarged or swollen, $\geq 3.0 \times$ longer than broad; $1=$ modified, distinctively swollen, enlarged, $\leq 2.8 \times$ longer than broad.

44. Protarsi: $0=$ unmodified, not enlarged or excavated, without conspicuous dark spots on inner surface; 1 = slightly or distinctly modified (fig. 5H).

45. Mesotibia with tooth or protuberance on inner surface: $0=$ absent, $1=$ present.

46. Mesotibial spur: $0=$ present; $1=$ absent.

47. Metafemur with patch of microtrichia (metafemoral keirotrichia) on posterior surface: $0=$ absent; $1=$ present (fig. $5 \mathrm{I}$ ).

48. Shape of transverse preapical carina of T6: $0=$ strong, medially emarginate, not toothed or denticulate (fig. 6A); $1=$ strong, entire or nearly so; 2 = strong, toothed or denticulate, with or without a median emargination.

49. T6, above preapical carina, with strong longitudinal median ridge or protuberance: 0 absent; $1=$ present.

50. Dorsal surface of T6: $0=$ bare or sparsely covered (integument visible) by long (2.0$3.0 \times \mathrm{OD})$ or short $(\leq \mathrm{OD})$ setae; $1=$ densely covered by short $(\leq \mathrm{OD})$, appressed branched setae.

51. Apical margin of $\mathrm{T} 6$ with lateral spine or tooth: 0 = absent; 1 = present.

52. Apical margin of T6 with submedian spine or tooth: $0=$ absent; $1=$ present.

53. Gradulus of T7:0 = without carina or weakly carinate; 1 = strongly carinate (fig. $6 \mathrm{~B}, \mathrm{C})$.

54. Transverse carina of T7: $0=$ rounded, truncate, or emarginate; 1 = angular (fig. 6B).

55. Dorsal lobe of gonocoxite: $0=$ absent (fig. 6D); 1 = present (fig. 6E, F). 

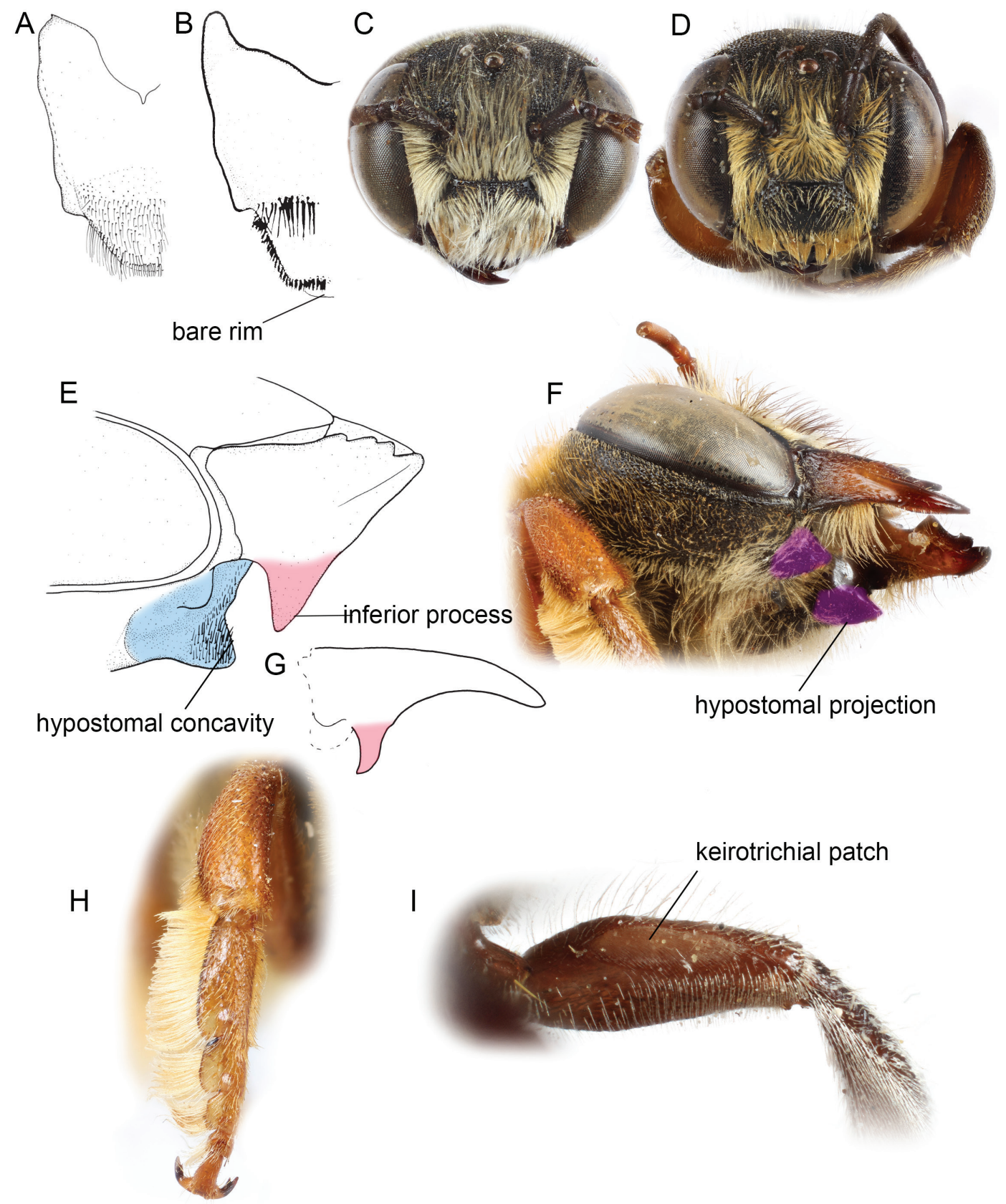

FIGURE 5. Some morphological features used in the phylogenetic analysis. A, B. Pubescence of apex of female sixth sternum. C, D. Pubescence of male clypeus. E-G. Modifications of the male mandible and hypostomal area. H. Modifications of male protarsus. I. Pubescence of posterosuperior surface of male metafemur. A. Megachile (Creightonella) cognata Smith (Uganda, Tororo, SEMC 1177151). B, E, G. M. (Acentron) albitarsis Cresson ( 9 , Costa Rica, San José, SEMC 1177780; ô, Costa Rica, Guanacaste, SEMC 1177784). C. M. (Chalepochile) ardua Mitchell (male holotype). D. M. (Aporiochile) tricosa Cockerell (male holotype). F, H. M. (Zonomegachile) gigas Schrottky (Brazil, Mato Grosso, ANSP 4133). I. M. (Chalepochile) tacanensis Moure (Argentina, Tucumán, SEMC 1184302). 

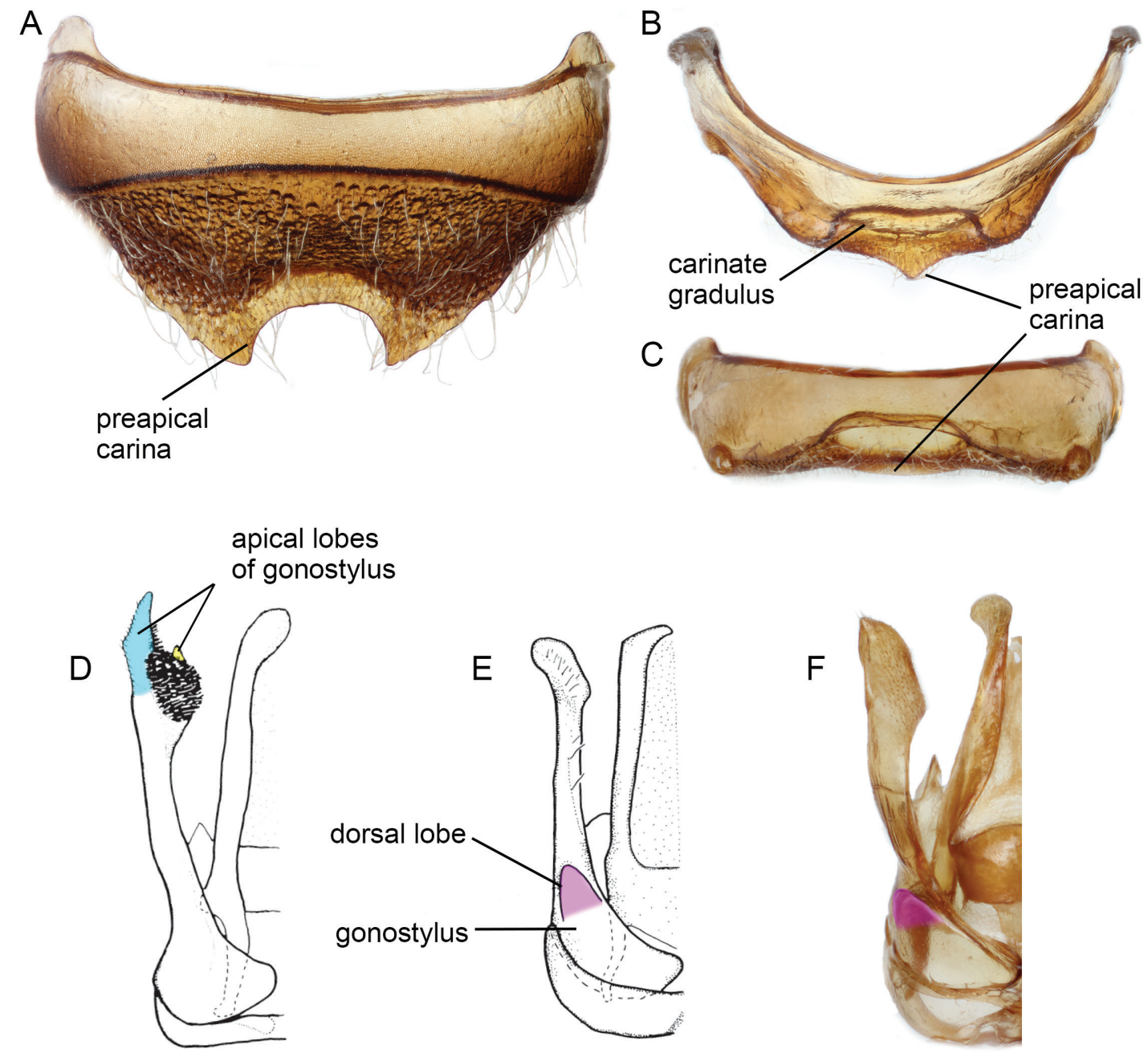

FIGURE 6. Some male morphological features used in the phylogenetic analysis. A. Tergum six in dorsal view. B, C. Tergum seven in dorsal and ventral views. D-F. Dorsal views of genital capsule. A-C. Megachile (Zonomegachile) moderata Smith (Bolivia, La Paz, SEMC 1204249). D. M. (Acentron) albitarsis Cresson (Costa Rica, Guanacaste, SEMC 1177784). E. M. (Austromegachile) montezuma Cresson (Brazil, São Paulo, SEMC 1178772). F. M. (Zonomegachile) kalina Gonzalez, Griswold, and Engel, new species (paratype, SEMC 1178968). 


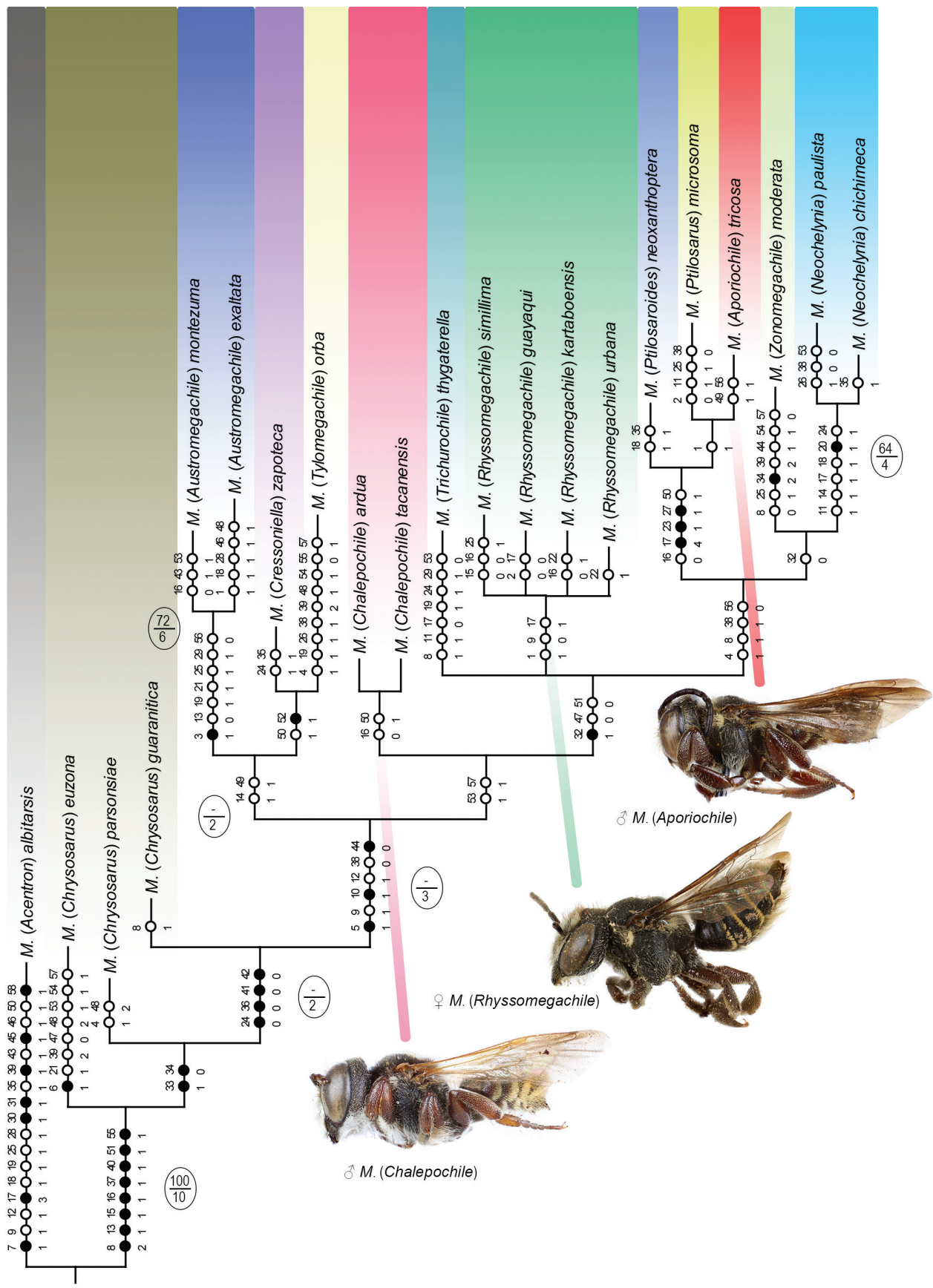

FIGURE 7. Cladistic placement of Aporiochile and Chalepochile among other leaf-cutter bees. Strict consensus tree of four most parsimonious trees. Black circles indicate unique characters; white circles indicate homoplastic changes; character numbers are placed above each change, character state below. Branch support indicated in circles, with bootstrap values (expressed as frequency differences GC) above bar and absolute Bremer values below. Branches without support value indicate bootstrap values below 50\% and Bremer values of 1 . 
56. Shape of dorsal lobe of gonocoxite: $0=$ large, strong, digitiform (fig. 6E); $1=$ small, acute (fig. 6F).

57. Length of gonostylus, in ventral view: $0=$ subequal to penis valves; $1=$ shorter than penis valves.

58. Apical lobes of gonostylus: $0=$ absent; $1=$ present (fig. 6D).

\section{PHYLOGENETIC RESULTS}

The analysis of the data matrix yielded four equally parsimonious trees $(\mathrm{L}=137, \mathrm{CI}=47$, RI $=57$ ); three nodes collapsed in the strict consensus topology. Neither Aporiochile nor Chalepochile clustered with Rhyssomegachile or Austromegachile (fig. 7). Chalepochile was recovered as sister to a large clade that included Aporiochile, Neochelynia, Ptilosaroides, Ptilosarus, Trichurochile, Rhyssomegachile, and Zonomegachile. Aporiochile was the sister group to Ptilosarus. No unambiguous synapomorphies support the monophyly of Rhyssomegachile and most branches in the cladogram were supported by low bootstrap and Bremer values (fig. 7).

\section{SYSTEMATICS}

\section{Genus Megachile Latreille}

Aporiochile Gonzalez and Engel, new subgenus

Figures 4B, 5D, 8-10

Type species: Megachile tricosa Cockerell, 1927.

Diagnosis: This subgenus is known only from the male. It can be easily recognized by the following combination of features: preoccipital carina strong behind gena, mesotibial spur present and articulated to mesotibia, procoxal spine present, mesoscutum with spaced punctures, and T6 with preapical carina strong, broad, and medially emarginate. It resembles Austromegachile, Ptilosarus, and Rhyssomegachile in the strong preoccipital carina behind the gena. However, it can be separated easily by the procoxal spine (absent in Ptilosarus), mesoscutal punctation (punctures contiguous or nearly so in Ptilosarus and Rhyssomegachile), and shape of the preapical carina of T6 (weak and inconspicuous in Austromegachile, reduced to triangular denticles in Ptilosarus). It superficially resembles the male of some species of Moureapis Raw in body size, punctation, presence of a procoxal spine, and shape of the preapical carina of T6. However, in Moureapis the preoccipital margin is rounded, the mandible is four-toothed with a basal process on its lower margin (mandible tridentate without basal process in Aporiochile), and the mesotibial spur is absent (present in Aporiochile).

Description: Male: Moderate-sized bees (7.0-8.0 $\mathrm{mm}$ in body length). Integument smooth and shiny among spaced punctures (figs. 4B, 8A, B). Antennal flagellum unmodified, F1 shorter than F2; preoccipital border strongly carinate on gena only; mandible tridentate, without basal projection or tooth on lower margin; hypostomal area unmodified, without a projection or concavity. Procoxa with short ( OD), blunt, apical spine; pro- and mesotibiae and tarsi unmodified; metafemur without a keirotrichial patch on posterosuperior surface; metabasitarsus elongate, about $3.9 \times$ longer than broad; mesotibial spur present, articulated to mesotibia, about as long as apical width of mesotibia. T6 swollen medially above strong, broad, medially emarginate preapical carina, without projections or spines on apical margin (fig. 8C); T7 not preapically projected into a spine or angle (fig. 9A, B); S5 and S6 with postgradular areas distinctly setose (fig. 9C, D); S4 exposed, with punctation and vestiture similar to those of preceding sterna; S8 without marginal setae (fig. 9E). Genital capsule elongate, flattened in lateral view; gonocoxite dorsally with distinct lobe (fig. 9F-H); gonostylus straight or nearly so in ventral view, broadest at midlength in lateral view, apically simple, unmodified, with long setae (about as long as width of gonostylus) along its medial margin; volsella present, apically rounded.

Female: Unknown. 

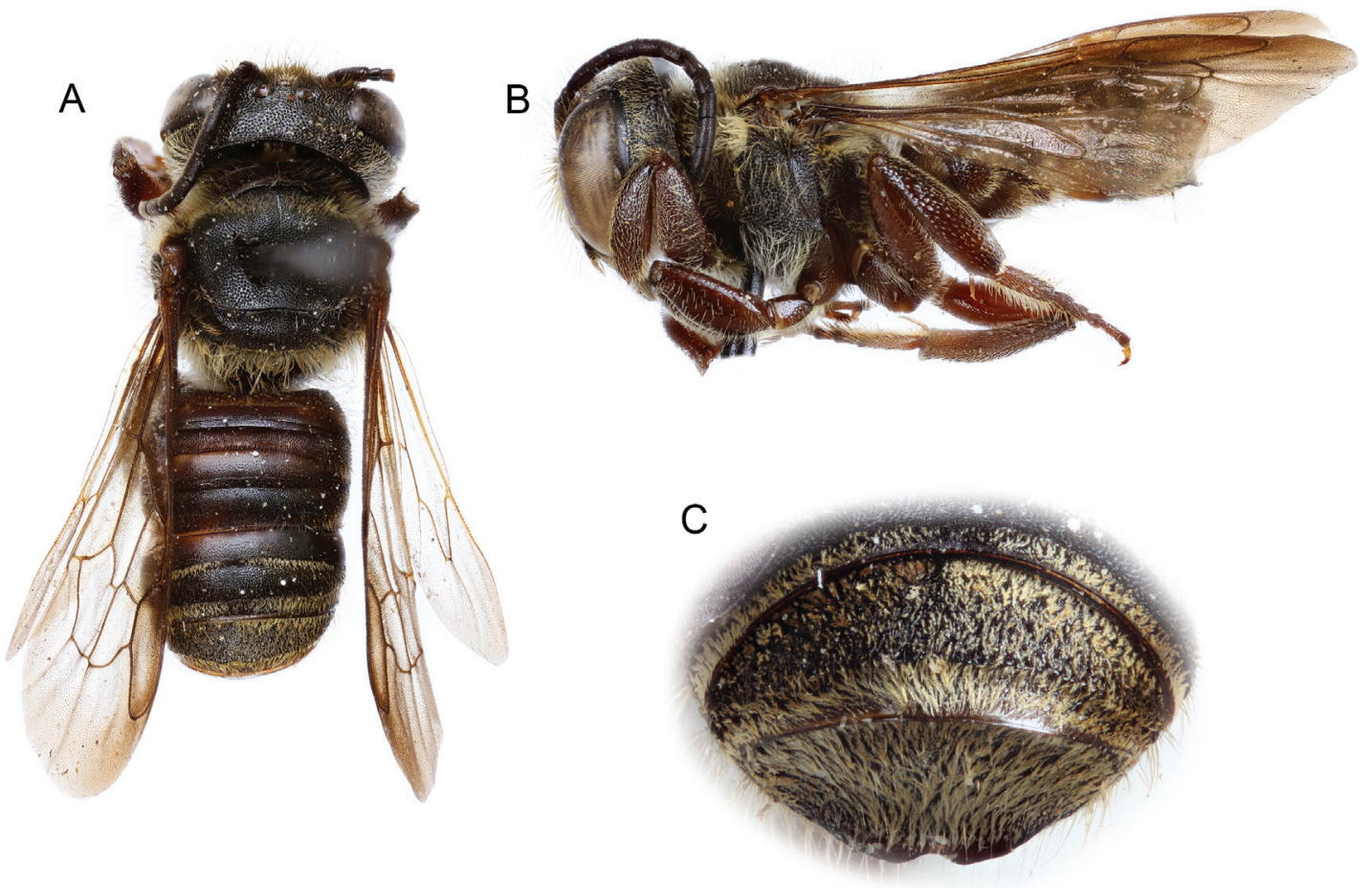

FIGURE 8. Male holotype of Megachile (Aporiochile) tricosa Cockerell. A. Dorsal habitus. B. Lateral habitus. C. Dorsal view of T5 and T6.

Eтrmology: The new genus group name is a combination of aporia (Greek, meaning, "difficult" or "doubt") and cheilos (Greek, "lip" or "rim"). Although the form of the name is technically a neuter plural, as is that of the genus Megachile, ${ }^{2}$ the gender of the name is here considered to be feminine.

Distribution: Bolivia, Brazil, Peru (fig. 10).

Comments: Megachile tricosa, the type species of Aporiochile, was described from a single male specimen collected in northwestern Bolivia. It was synonymized under M. (Rhyssomegachile) urbana Smith (Moure et al., 2007), a species currently known only from the female holotype. However,

2 The generic name Megachile derives from Greek mega and chile, meaning "large lips" or "large rims"; because chile is a neuter (plural of $\chi \varepsilon \tilde{\varepsilon} \lambda$ oఢ) it should be treated as a masculine according to nomenclatural conventions, but in fact based on the application of feminine adjectives for specific names, it appears that authors have considered the genus feminine. We thus follow universal usage and consider Megachile and similar names derived from $\chi \varepsilon \tilde{\imath} \lambda$ o nine gender. both species are likely not conspecific judging by the smoother and shiner integument of M. tricosa, particularly on the mesoscutum (fig. 4B). In $M$. urbana the integument is dull and more coarsely punctate. In addition, $M$. tricosa does not share the diagnostic characters of Rhyssomegachile and our phylogenetic analysis does not suggest a close relationship to that subgenus (fig. 7). For example, $M$. tricosa has a short procoxal spine and sterna densely covered with fasciae, both features absent in the male of M. (Rhyssomegachile) simillima. In our analysis $M$. tricosa did not cluster with Rhyssomegachile and reanalyzing the data matrix using a terminal taxon that combined characters of both $M$. tricosa and M. urbana resulted in a large polytomy that included species from different subgenera (not shown). Thus, until sex associations or genetic evidence is available, we decided to place $M$. tricosa in its own subgenus, which is consistent with our present understanding of its relationships. 

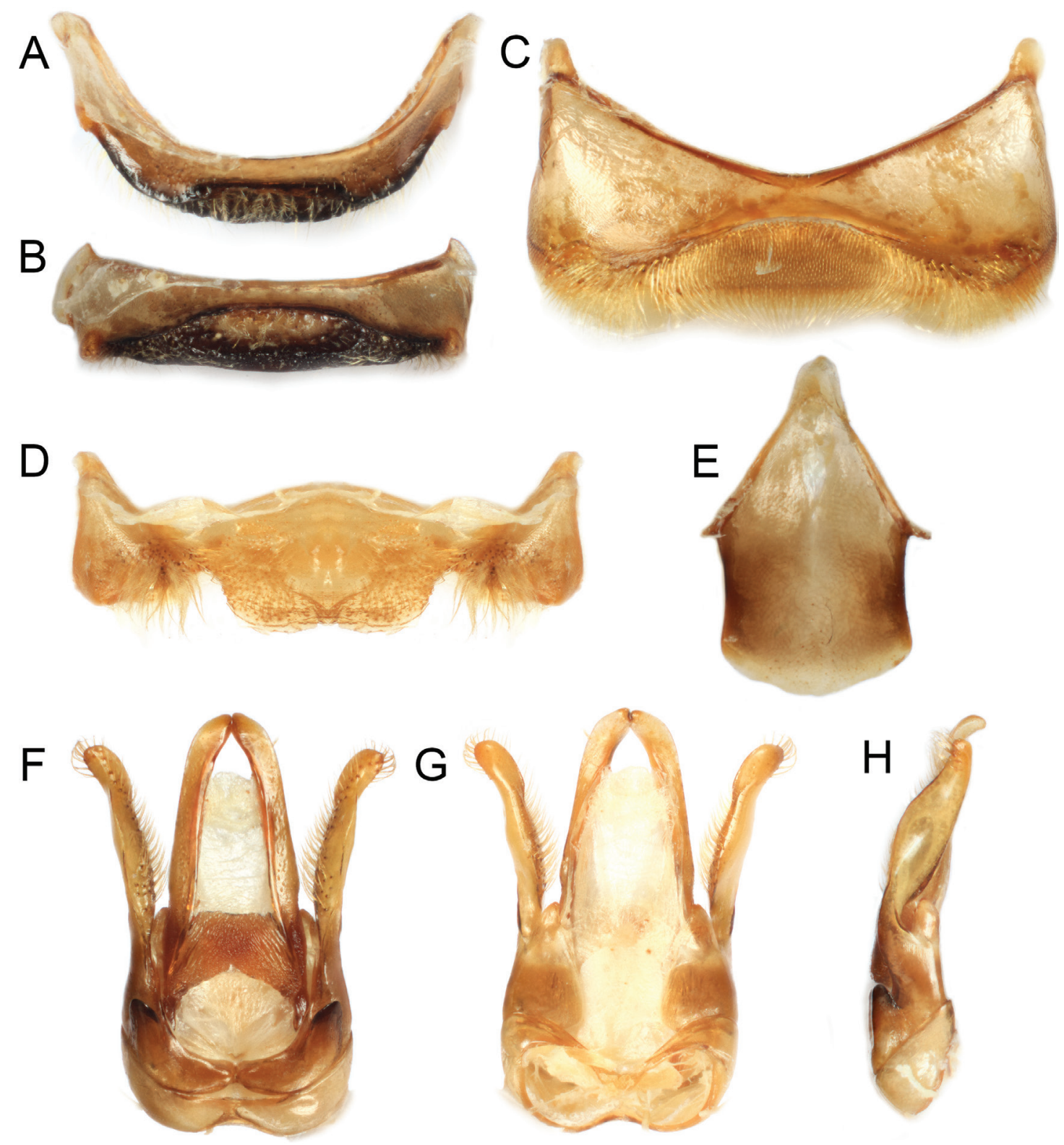

FIGURE 9. Male of Megachile (Aporiochile) tricosa Cockerell (Peru, Madre de Dios, SEMC 255772). A, B. Seventh tergum in dorsal and ventral views. C. Fifth sternum. D. Sixth sternum. E. Eighth sternum. F-H. Genital capsule in dorsal, ventral, and lateral views. 


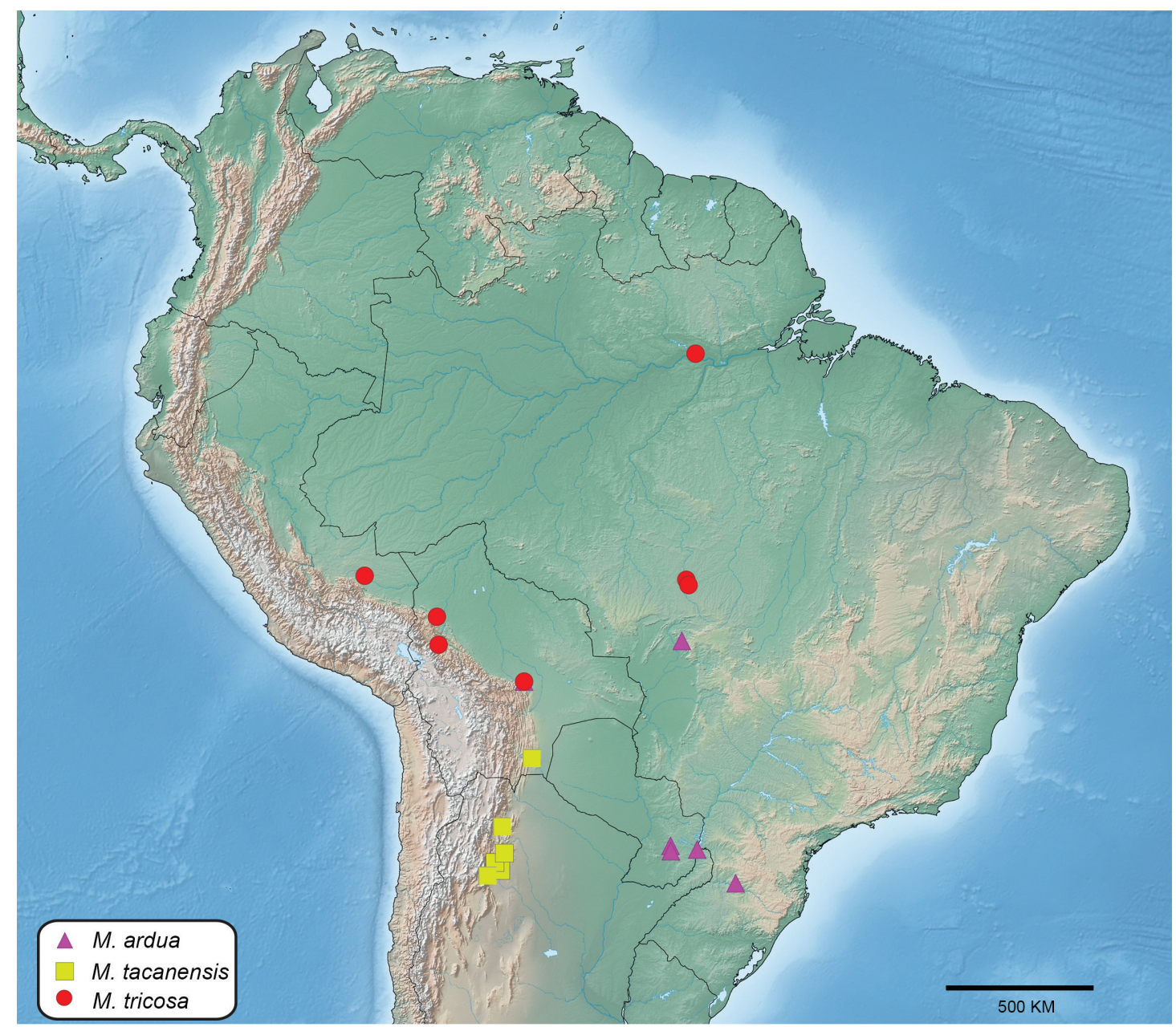

FIGURE 10. Collection localities for Megachile (Aporiochile) tricosa Cockerell, M. (Chalepochile) ardua Mitchell, and M. (Chalepochile) tacanensis Moure.

Megachile (Aporiochile) tricosa Cockerell,
resurrected status

Figures 4B, 5D, 8-10

Megachile tricosa Cockerell, 1927: 21 (holotype ô, examined, USNM 29092: Tumupasa, La Paz, Bolivia). Raw, 2002: 6 (placement in Austromegachile Mitchell). Moure et al., 2007: 992 (synonymy under M. urbana Smith). Megachile turbulenta Mitchell, 1930: 255 (neotype $\widehat{\delta}$ [here designated], NCSU 0006818: Buenavista, Bolivia). Mitchell, 1943: 667 (placement in Austromegachile). Moure et al., 2007: 992 (placement in Rhyssomegachile Mitchell). New synonymy.

Diagnosis: As for the subgenus (above).

Redescription: Holotype. Male: Total body length $8.9 \mathrm{~mm}$; forewing length $7.8 \mathrm{~mm}$; head width $3.6 \mathrm{~mm}$. Head $1.4 \times$ wider than long; inner orbits of compound eyes slightly converging below; intertorular distance $1.7 \times$ torulorbital distance; interocellar distance $1.6 \times \mathrm{OD}, 0.7 \times$ ocellocular distance; ocelloccipital distance $3.2 \times \mathrm{OD}$, $1.4 \times$ ocellocular distance; scape $2.5 \times$ longer than 
broad, pedicel about as long as F1, each about as long as broad, F2 1.6× longer than F1, longer than broad as in remaining flagellomeres, distalmost flagellomere longest, apically flattened, not expanded. Genital capsule and associated terga and sterna as in figure 9.

Body color black, except dark reddish brown on tegula, legs, and metasoma. Wings slightly brownish, darker on radial cell apically, first submarginal, and marginal cells; veins and pterostigma dark brown.

Pubescence light reddish yellow, except: white on mesepisternum, coxae, trochanters, and sterna; dark brownish gray on discs of T2-T4. Clypeus sparsely covered by setae (integument largely visible among setae) on basal three fourths, densely covered by setae (integument not visible among setae) on apical one fourth. Meso- and metabasitarsi with short setae along anterior margin, at most as long as maximum basitarsal width. T1 with long (1.5-2.0× OD), erect setae; T2-T4 with shorter ( $\leq \mathrm{OD})$, appressed setae sparsely covering integument; sides of T2 and $\mathrm{T} 3$, depressed marginal zone of $\mathrm{T} 4$, and $\mathrm{T} 5$ and T6 densely covered by appressed, short, minutely branched setae (integument not visible among setae); S1-S4 with long (1.0-1.5× OD), dense, white apical fasciae (integument not visible among setae).

Clypeus smooth and shiny with smaller, sparser (1.0-3.0 $\times \mathrm{PW})$ punctures on disc than on sides; supraclypeal area contiguously punctate, punctures small as on clypeal disc; frons coarsely and contiguously punctate, surface among punctures angular; paraocular areas with similar punctation as on frons, punctures smaller; vertex smooth and shiny with coarse, spaced $(\leq 1.0 \times$ $\mathrm{PW}$ ) punctures smaller than those on frons; upper gena with shallower, punctures than on vertex. Pronotum weakly imbricate with smaller, sparser, shallower punctures than on mesoscutum; mesoscutum weakly imbricate, somewhat dull, punctures separated by $1.0-2.0 \times$ a puncture width on disc, contiguous or nearly so along lateral and posterior margins; mesoscutellum and axilla dorsally with punctures slightly denser than on disc of mesoscutum; mesepisternum smooth and shiny with punctures larger $(1.5 \times)$ than on mesoscutum, separated at most by a puncture width, punctures becoming smaller and closer dorsally; metepisternum and propodeum imbricate, punctures oval, faint, spaced (1.0-2.0× PW) on metepisternum, about as large as those on mesoscutum; lateral surface of propodeum with oval, smaller, fainter, closer punctures than on metepisternum, posterior surface of propodeum with widely separated (2.0-4.0× PW) punctures; metanotum finely and minutely $(\leq 1.0 \times \mathrm{PW})$ punctate; legs weakly imbricate to smooth and shiny, coarsely and densely $(\leq 1.0 \times$ PW) punctate, punctures larger and sparser on hind legs. Terga weakly imbricate to smooth and shiny, minutely and densely (1.0-1.5× PW) punctate, punctures becoming coarser and denser toward apical terga, T4 and T5 with depressed, smooth, shiny, brown apical margins; sterna strongly imbricate, with coarser, sparser punctures than on terga.

Female: Unknown.

Holotype (M. tricosa): đ, Tumupasa, Bolivia, Dec., W.M. Mann/Mulford Biol. Expl. 1921-1922/Megachile tricosa Ckll. Type/Type No. 29092 U.S.N.M. (USNM).

Neotype (M. turbulenta): đิ, Buenavista, Dep. Sta. Cruz, Bolivia, 450 m.h./QR barcode NCSU 0006818/ ठ Megachile turbulenta Mitchell, Paratype (greenish label)/ 0 Neotype Megachile turbulenta Mitchell, des. V.H. Gonzalez, M.S. Engel, \& T. Griswold 2016 (NCSU). Megachile turbulenta Mitchell was described from two male specimens, the holotype of which was lost during World War II (see Material and Methods, above). To stabilize this name, we here designate as neotype the sole male paratype in accordance with Article 75 of the ICZN (1999).

AdDitional MATERial EXAmined $(n=$

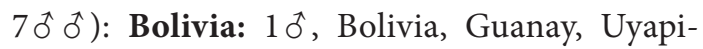
X-95, Gerlach/AMNH_IZC 00290233 (AMNH); $1 \hat{\delta}$, ut supra (AMNH); $1 \hat{0}$, Region Chapare, Bolivia, $400 \mathrm{~m}$, VIII-1950, Zischka/SEMC 1176839 (SEMC). Brazil: 10, Colonia rio Bronco, Obido, Para, Brazil, x-1953, J. Bpozllno/ 
COLECÃO CAMPOS SEABRA/NCSU 0004717; 1 $0^{\top}$, Brazil: Matto Grosso: $12^{\circ} 31^{\prime} \mathrm{N}, 55^{\circ} 37^{\prime} \mathrm{W}$, Sinop. Oct. 1975 (AMNH); $10^{\dagger}$, Matto Grosso: Vila Vera, $55^{\circ} 30^{\prime}$ long., $12^{\circ} 46^{\prime}$ lat., Oct. 1973, M. Alvarenga (AMNH). Peru: $1 \delta^{\dagger}$, Peru, Madre de Dios, Pakitza Bio. Sin., Reserved Zone, Manu National Park, 317 m, 11 $56^{\circ} 41^{\prime \prime}$ S, $71^{\circ} 17^{\prime} 0^{\prime \prime} \mathrm{W}, 16$ Oct 2000; R. Brooks, PERU 1B00 008, ex: wet area near stream/SM0255772 (SEMC).

Distribution: Bolivia (La Paz, Santa Cruz), Brazil (Pará), Peru (Madre de Dios) (fig. 10).

Comments: Aside from a slightly larger body size of the neotype of $M$. turbulenta when compared with the holotype of $M$. tricosa, we did not find significant differences in the punctation, pubescence, or shape of the preapical carina of T6.

\section{Chalepochile Gonzalez and Engel, new subgenus}

Figures 5C, I, 10-13

Type sPecies: Megachile ardua Mitchell, 1930.

Diagnosis: This subgenus is known only from the male. It can be easily recognized by the following combination of features: preoccipital margin rounded, mesoscutum with coarse and contiguous punctures, mesotibial spur present and articulated to mesotibia, procoxal spine absent, metafemur with keirotrichial patch on posterosuperior surface (fig. 5I), meso- and metabasitarsi with a fringe of long $(\geq 2.0 \times$ maximum basitarsal width) setae, metabasitarsus short $(\sim 3.0 \times$ longer than broad), and T6 with preapical carina strong, broad, and medially emarginate. This subgenus resembles Ptilosarus, Ptilosaroides, and Rhyssomegachile in the small body size (4.0$5.0 \mathrm{~mm}$ in body length) and coarsely and contiguously punctate mesoscutal integument (fig. 11A, B). It differs from Ptilosarus and Rhyssomegachile in the preoccipital margin rounded (carinate in both of the mentioned subgenera), meso- and metabasitarsi with a fringe of long setae (short in both subgenera, at most as long as width of basitarsus), and metafemur with keirotrichial patch (absent in both subgenera). Ptilosaroides has a rounded preoccipital margin, but it possesses a procoxal spine (absent in Chalepochile) and lacks the long fringe of setae on meso- and metabasitarsi, as well as the keirotrichial patch of the metafemur. The new subgenus shares with Austromegachile a clypeus that is densely pubescent throughout and the presence of a keirotrichial patch on the metafemur. However, in Austromegachile the preoccipital margin is carinate behind the gena and the preapical carina of T6 is weak and inconspicuous, often entire or weakly emarginate (preapical carina strong, medially emarginate, with lobe lateral to emargination orthogonal in Chalepochile).

Description: Male: Small bees (4.0-5.0 $\mathrm{mm}$ in body length). Integument with coarse, contiguous punctures. Antennal flagellum unmodified, F1 shorter than F2; preoccipital margin rounded, not carinate; mandible tridentate, without basal projection or tooth on lower margin; hypostomal area unmodified, without projections or depressed areas. Procoxa unmodified, without a spine; pro- and mesotibiae and tarsi unmodified; metafemur with keirotrichial patch on posterosuperior surface; metabasitarsus elongate, about $2.9 \times$ longer than broad (fig. 11C); mesotibial spur present, articulated to mesotibia, about as long as apical width of mesotibia. T6 barely protuberant medially at base, concave above preapical carina, preapical carina strong, medially emarginate, with lobe lateral to emargination orthogonal (fig. 11D), distal margin with small but distinct lateral and submedian projections (fig. 12A); T7 preapically angled (fig. 12B, C); S4 exposed, with punctation and vestiture similar to those of preceding sterna; S5 and S6 with postgradular areas distinctly setose (fig. 12D, E); S8 without marginal setae (12F). Genital capsule (fig. 12G-I) elongate, $1.5 \times$ longer than wide, more robust than that of Aporiochile; gonocoxite dorsally with very small, orthogonal projection (less conspicuous than that of Rhyssomegachile and 


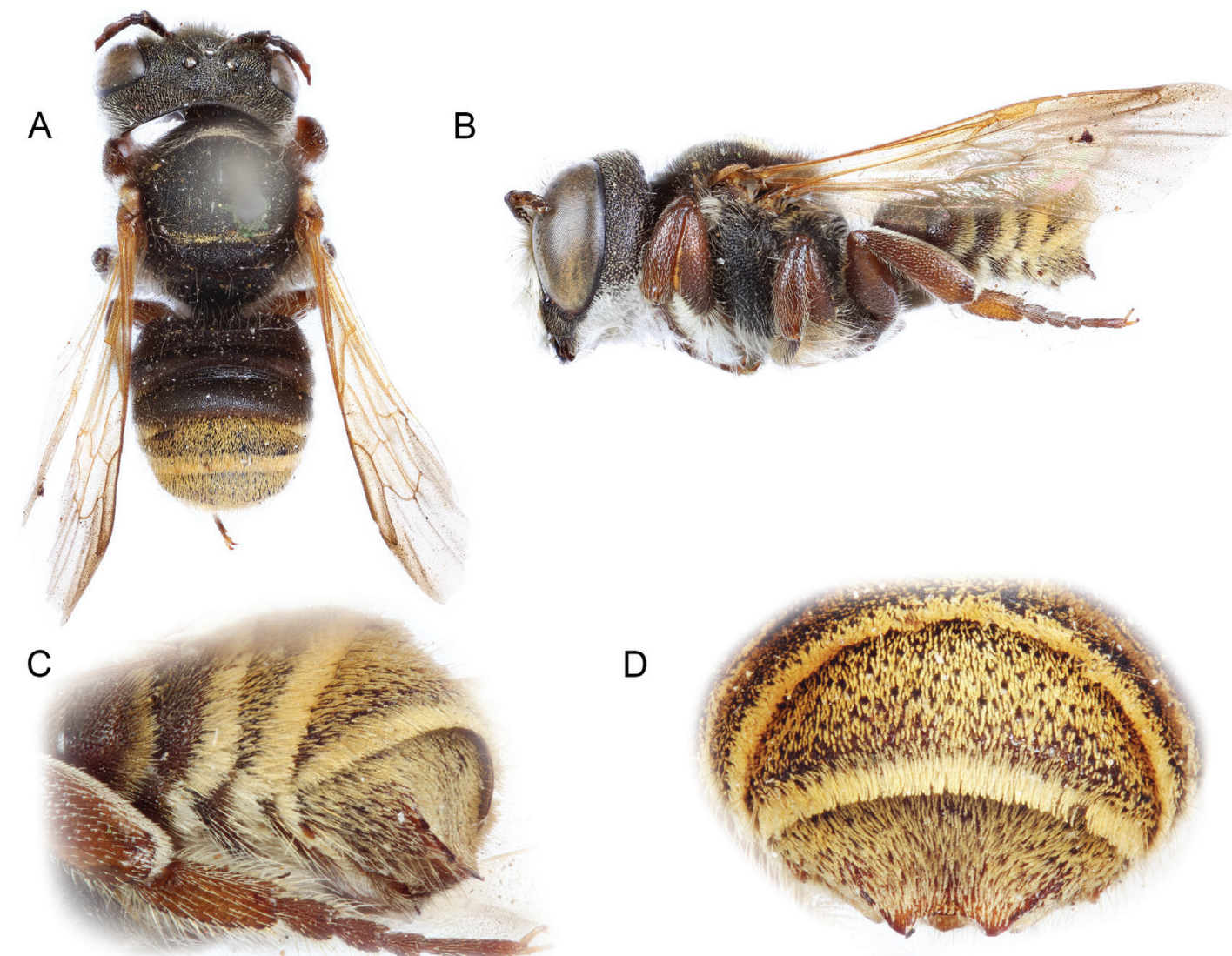

FIGURE 11. Male holotype of Megachile (Chalepochile) ardua Mitchell. A. Dorsal habitus. B. Lateral habitus. C. Ventrolateral view of terminal metasomal terga and outer surface of metabasitarsus. D. Dorsal view of T5 and T6.

Aporiochile); gonostylus straight or nearly so in ventral view, broadest at apex in lateral view, apically sinuous (appearing simple and unmodified at low magnifications), with setae along its medial margin about as long as width of gonostylus; volsella present, narrowly rounded at apex.

Female: Unknown.

ЕтумоLOGY: The new group-name is a combination of chalepos (Greek, meaning, "difficult") and cheilos (Greek, "lip" or "rim"). The gender of the name is feminine.

Distribution: Argentina, Bolivia, Brazil, Paraguay (fig. 10).

Comments: This subgenus includes two morphologically similar species, both known only from the male sex: M. ardua and M. tacanensis.
Megachile (Chalepochile) ardua Mitchell

Figures 5C, 11, 12

Megachile ardua Mitchell, 1930: 268 (holotype o, examined, ANSP 4124: Chapada dos Guimarães, Mato Grosso, Brazil). Schlindwein, 1998: 53 (placement in Ptilosaroides Mitchell). Raw, 2002: 32 (placement in Ptilosarus Mitchell). Moure et al., 2007: 991 (placement in Rhyssomegachile Mitchell).

Diagnosis: This species can be distinguished from $M$. tacanensis (see below) by the pubescence of the metasoma. In M. ardua, T4-T6 are densely covered (integument barely visible) with short, appressed, minutely branched yellow setae contrasting with the preceding terga, which are 


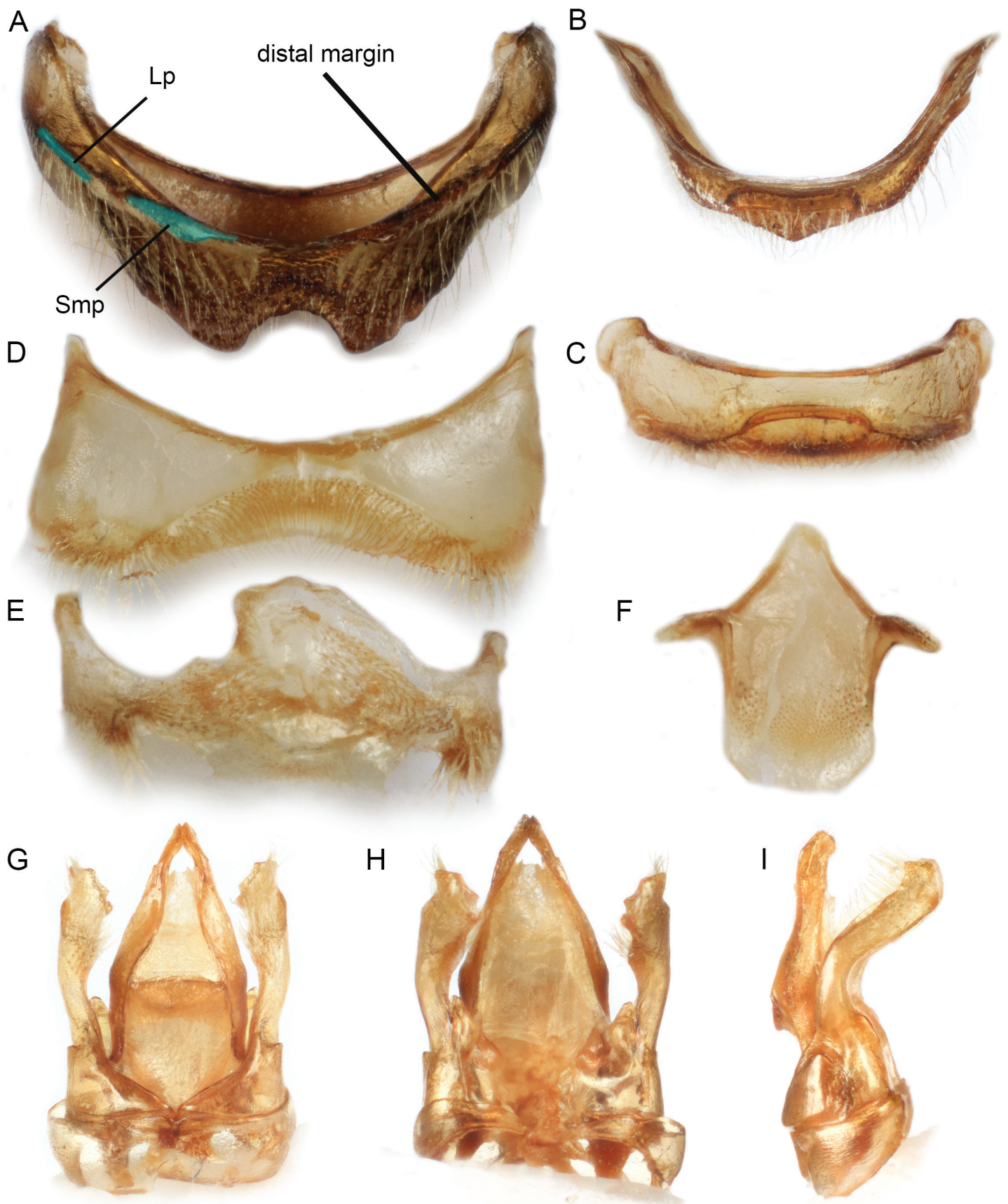

FIGURE 12. Male of Megachile (Chalepochile) ardua Mitchell (Brazil, Santa Catarina, Nova Teutônia, SEMC 1184289). A. Sixth tergum, inner view. B, C. Seventh tergum in dorsal and ventral views. D. Fifth sternum. E. Sixth sternum. F. Eighth sternum. G-I. Genital capsule in dorsal, ventral, and lateral views. Lp = lateral projection; Smp $=$ submedian projection. 
sparsely covered with semierect, mostly simple or poorly branched, dark brownish-gray setae (fig. 11). In M. tacanensis, T1-T4 are sparsely covered with semierect, mostly simple or poorly branched, dark brownish-gray setae, and T5 and T6 are sparsely covered (integument largely visible) with short, appressed, minutely branched whitish setae (fig. 13). In addition, the presence of black setae basally on the clypeus differentiates $M$. ardua from $M$. tacanensis.

Redescription: Holotype, Male: total body length $4.8 \mathrm{~mm}$; forewing length $4.0 \mathrm{~mm}$; head width $3.0 \mathrm{~mm}$. Head $1.3 \times$ wider than long; inner orbits of compound eyes converging below; intertorular distance about twice as long as torulorbital distance; interocellar distance about twice as long as $\mathrm{OD}, 0.8 \times$ ocellocular distance; ocelloccipital distance $2.8 \times \mathrm{OD}$, about as long as ocellocular distance; scape $2.3 \times$ longer than broad, pedicel about as long as F1, each about as long as broad, F2 1.8 $\times$ longer than F1, longer than broad. Genital capsule and associated terga and sterna as in figure 12.

Body color black, except reddish-brown tegula, legs, and metasoma. Wing membrane and veins reddish yellow basally, dark brown distally.

Pubescence white except: clypeus basally with a row of black setae; vertex, disc of mesoscutum, and basitarsi with light reddish-yellow setae; mesoscutum-mesoscutellar sulcus, apical margins of T3 laterally, and T4-T6 with yellow setae; pronotum, lateral margins of mesoscutum, mesoscutellum, and T1-T3 with dark brownish-gray setae. Clypeus, supraclypeal area, and inferior paraocular area densely covered by long (1.0-2.0× OD) setae. Metafemur with keirotrichial patch on its posterosuperior surface; meso- and metabasitarsi with fringe of long ( $\geq 2.0 \times$ maximum basitarsus width) setae. T4-T6 densely covered (integument barely visible) with short, appressed, minutely branched yellow setae contrasting with T1-T3 sparsely covered with semierect, mostly simple or poorly branched, dark brownish-gray setae; S2-S4 with dense apical fasciae (integument not visible among setae).
Face and vertex with coarse and contiguous punctures, surface among punctures rounded except on frons with angular surface; gena shiny, with shallower punctures than on vertex, punctures becoming smaller inferiorly. Pronotum strongly imbricate with smaller, sparser, shallower punctures than on mesoscutum; mesoscutum, mesoscutellum, and axilla with coarse and contiguous punctures, surface among punctures angular; mesepisternum alveolate, alveoli larger than punctures on mesoscutum, becoming smaller dorsally and larger, circular ventrally; metepisternum and lateral and posterior surfaces of propodeum strongly imbricate, punctures oval, faint, spaced $(\leq 1.0 \times \mathrm{PW})$, propodeal triangle microalveolate; metanotum weakly imbricate with fine, scattered punctures; legs weakly imbricate to smooth and shiny with coarse, spaced $(\leq 1.0 \times \mathrm{PW})$ punctures, except pro- and mesotibiae with shallower punctures. Terga weakly imbricate to smooth and shiny, minutely and densely (1.0-1.5× PW) punctate, punctures becoming coarser and denser toward apical terga; sterna strongly imbricate, with coarser, sparser punctures than on terga.

Female: Unknown.

Holotype: ơ, [Brazil: Mato Grosso] pada [Chapada dos Guimarães]/Megachile ardua $\hat{0}$, Mitchell, Type 4124 (ANSP).

ADDITIONAL MATERIAL EXAMINED $(n=$ 8 ๙ో): Argentina: 10, Iguazú, Misiones, Arg. [Argentina], X-10-1950 [10 October 1950], M. Senknto/SEMC 1184301 (SEMC). Bolivia: $1 \hat{0}$, Buenavista, Dep. Sta. Cruz, Bolivia, 450 m.h./M. (Ptilosarus) ardua Mitchell as det. 1982 in T.B. Mitchell collection/QR barcode NCSU 0003994/ ơ Megachile ardua Mitchell, Paratype (greenish label) (NCSU). Brazil: 10, Nova Teutonia, Santa Caterina, Brazil, X-1951 [October 1951], L.E. Plaumann/Homotype, Megachile ardua Mitch., J.S. Moure 1957/ SEMC 1184289 (SEMC). Paraguay: 1 $\widehat{0}$, Paraguay, Caaguazú, December 1958, (F.H. Walz)/SEMC 1184293 (SEMC); 1 đે, Paso Yobai, Paraguay, 12-XI-1951 [12 November 1951], Juan Foerster/SEMC 1184300 (SEMC); 4 ô $\widehat{o}$, Paraguay: San Pedro, 
Corono-Rio Ypane, XI-28/30-1983 malaise trap, M. Wasbauer (BBSL).

Distribution: Argentina (Misiones), Bolivia (Santa Cruz), Brazil (Mato Grosso, Rio Grande do Sul), Paraguay (Caaguazú, Guairá, San Pedro Corono) (fig. 10).

Comments: The holotype is in a good condition except for the right metatibia and remaining podites of the leg and antennal flagella are missing.

Megachile (Chalepochile) tacanensis Moure

Figures 5I, 13

Megachile ardua tacanensis Moure, 1948: 322 (holotype đ̊, DZUP: Tacanas, Tucumán, Argentina). Moure et al., 2007: 991 (species rank, placement in Rhyssomegachile Mitchell).

Diagnosis: This species is known only from the male sex. Based on the original description as well as the material examined here, this species can be easily separated from $M$. ardua by the following combination of features: T1-T4 sparsely covered with semierect, mostly simple or poorly branched, dark brownish-gray setae, and T5 and T6 sparsely covered (integument largely visible) with short, appressed, minutely branched whitish setae.

Female: Unknown.

Material examined $(n=108 \precsim \widehat{\diamond})$ : Argentina: 10 , El Cadillal Prov., Tucumán, Arg. [Argentina], X-1951, Foester/Megachile ardua tacanensis, Det. J.S. Moure 1957/M. (Ptilosarus) ardua Mitchell as det. 1982 in T.B. Mitchell collection/QR barcode NCSU 0003998 (NCSU); 10 , ut supra, SEMC 1184303 (SEMC); 10, San Pedro de Colalao, Trancas, Tucumán, Arg. [Argentina], II-1948, Arnan J. Foerster/Megachile ardua tacanensis, Det. J.S. Moure 19?/ SEMC 1184302 (SEMC); 10 , Rosario de la Frontera, Salta, Argentina, XI-1950, A.F. Prosen/ardua/ SEMC 1184291 (SEMC); $2 \widehat{\delta}$, ARG [Argentina], Tucuman, X-19-[19]72, G.E. Bohart, Argemon fusciformis [Papaveraceae] (BBSL); 2 ô $\widehat{0}$, ARG [Argentina],
S.D. Estero [Santiago del Estero], Las Termas, X-11-[19]72, G.E. Bohart, Prosopis alba [Fabaceae] (BBSL). Bolivia: 10, Tarija, Villa Montes,

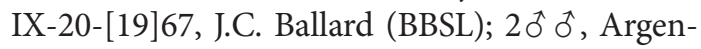
tina, Catamarca, La Merced, 16 km N, 23-25 Oct 2003, M.E. Irwin, F.D. Parker (BBSL); 10 , Argentina, Catamarca, La Merced, 9 km N, 24 Oct-14 Nov 2003, F.D. Parker, M.E. Irwin (BBSL); 59 ๙ Argentina, Catamarca, La Merced, 9 km N, 25 Oct 2003, F.D. Parker, M.E. Irwin (BBSL); 2 के $\hat{0}$, Argentina, Catamarca, Trampasacha, $8 \mathrm{~km} \mathrm{~W}$ Chumbicha, 24 Oct 2003, M.E. Irwin, F.D. Parker (BBSL); $2 \hat{\widehat{0}}$, Argentina, Catamarca, Trampasacha, $8 \mathrm{~km}$ W Chumbicha, 24 Oct-12 Nov 2003, M.E. Irwin, F.D. Parker (BBSL); $200 \hat{\jmath}$, Argentina, Catamarca, Trampasacha, $8 \mathrm{~km}$ W Chumbicha, 25 Oct 2003, M.E. Irwin, F.D. Parker (BBSL); 8 o $\widehat{\jmath}$, Argentina, Jujuy, Arroyo Las Lanzas, $36 \mathrm{~km}$ S Jujuy, 22-27 Oct 2003, M.E. Irwin, F.D. Parker (BBSL); $50 \hat{\jmath}$, Argentina, Jujuy, 27 km N, 27 Oct14 Nov 2003, M.E. Irwin, F.D. Parker (BBSL).

Distribution: Argentina (Catamarca, Jujuy, Salta, Santiago del Estero, Tucumán), Boliva (Tarija) (fig. 10).

Comments: The holotype of this species was not available for examination, but the original description provided pertinent details and material determined by the late Padre Moure was available (above).

Subgenus Rhyssomegachile Mitchell

Figures 1, 4A, C, D, E, 14-20

Cressoniella (Rhyssomegachile) Mitchell, 1980: 63.

Type species: Megachile simillima Smith, 1853, by original designation. Michener, 2007: 582.

DiAgnosis: This subgenus can be easily recognized by the following combination of features: preoccipital carina strong behind gena; female mandible (fig. 1) with four acute teeth of similar size except fourth tooth, which is truncate and incised, with incomplete interdental laminae in second and third interspaces hidden 


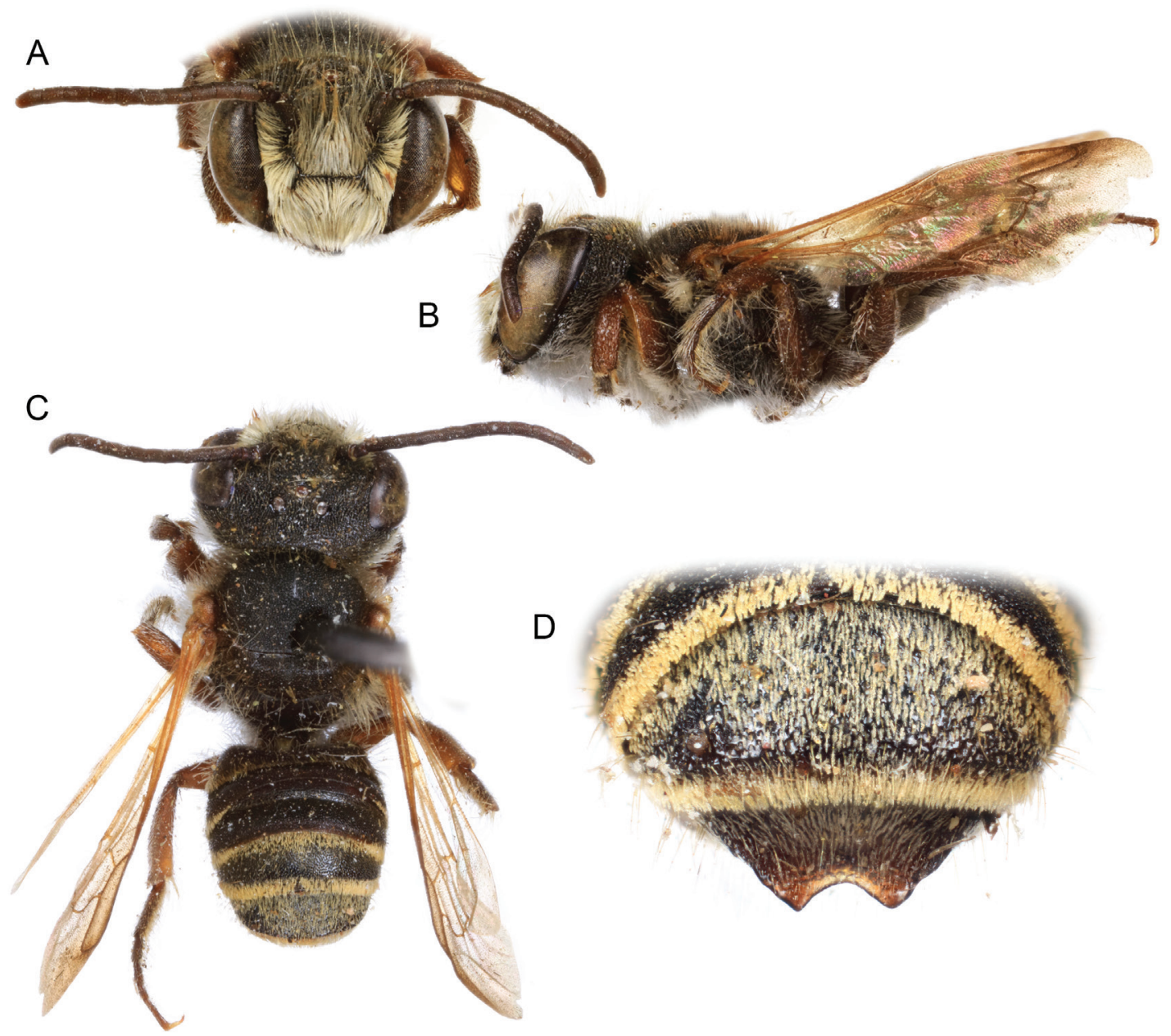

FIGURE 13. Male of Megachile (Chalepochile) tacanensis Moure (Argentina, Salta, SEMC 1184291). A. Facial view. B. Lateral habitus. C. Dorsal habitus. D. Posterior view of T5 and T6.

behind interspace margin (appearing to lack interdental laminae in frontal view in some specimens with worn mandibles); mesoscutal integument coarsely and contiguously punctate (fig. 4A); female T6 straight in profile; female S6 with well-dispersed scopal setae; male mandible tridentate, without basal projection on lower margin; male mesotibial spur present and articulated to mesotibia; male procoxal spine absent; male T6 with preapical carina strong, broad, and medially emarginate. It resembles Aporiochile, Austromegachile, and Ptilosarus in the strong preoccipital carina behind the gena. However, it can be separated by the male procoxal spine (present in Aporiochile), male T6 (weak and inconspicuous in Austromegachile, reduced to triangular denticles in Ptilosarus), mesoscutal pubescence (short and appressed in Ptilosarus, sparse in Rhyssomegachile), and female S2 with unmodified scopal setae (S2 densely covered by fine, plumose setae contrasting with unmodified setae on remaining sterna in Ptilosarus).

ReDESCRIPTION: Moderate-sized bees (8.0$12.0 \mathrm{~mm}$ in body length). Integument dull, with punctures coarse and contiguous (except on disc of $M$. urbana). Preoccipital border strongly cari- 
nate on gena in both sexes (continuing onto vertex in M. guayaqui Schrottky).

Female: Mandible short, apically broad, with four acute teeth of similar size except fourth tooth, which is truncate and incised, incomplete interdental laminae in second and third interspaces hidden behind interspace margin (specimens with worn mandibles appear to lack interdental laminae in frontal view), outer surface coarsely punctate, carinae usually smooth and shiny; ocelloccipital distance greater than ocellocular distance. Metasoma cordate, with white apical fasciae, at least laterally, on T1-T5, without premarginal lines on $\mathrm{T} 2-\mathrm{T} 5$; sterna without apical fasciae beneath scopa; S6 with well-dispersed scopal setae; T6 straight in profile, sometimes with few erect setae arising from decumbent pubescence.

Male: Antennal flagellum unmodified, F1 shorter than F2; mandible tridentate, without basal projection or tooth on lower margin; hypostomal area unmodified, without a projection or concavity; procoxa aspinose; pro- and mesotibiae and tarsi unmodified; metafemur without a keirotrichial patch on its posterosuperior surface; metabasitarsus elongate, about 3.7x longer than broad; mesotibial spur present, articulated to mesotibia, about as long as apical width of mesotibia. T6 basally swollen, with strong, broad preapical carina medially emarginated, distal margin without a distinct tooth or projection; T7 with preapical carina slightly projected medially; S5 and S6 with postgradular areas sparsely covered by setae; S4 exposed, with punctation and vestiture similar to those of preceding sterna; S8 without marginal setae. Genital capsule elongate, $1.6 \times$ longer than wide, more robust than that of $M$. (Aporiochile); gonocoxite dorsally with small, acute lobe; gonostylus straight or nearly so in ventral view, narrowest at midlength in lateral view, apically simple, unmodified, with setae (at most as long as width of gonostylus) along its medial margin; volsella present, apically rounded.

Distribution: Boliva, Brazil, Colombia, Ecuador, Guyana, Peru, Venezuela (fig. 14).
Comments: We recognize four species in Rhyssomegachile (table 1). Megachile simillima is the most widely distributed species (fig. 14) and the only one with both sexes known. Remaining species are known only from the female sex and each appears to have restricted distributions. While female specimens of Rhyssomegachile can correctly be identified to subgenus using the key to the subgenera of Megachile s.l. of Michener (2007), male specimens run to Austromegachile because of the absence of a procoxal spine. In addition to differences in the preapical carina of T6 mentioned in the diagnosis, the male of Rhyssomegachile can be distinguished from that of Austromegachile by the pubescence of the clypeus, which is largely bare basally in the former and uniformly pubescent in the latter.

Megachile (Rhyssomegachile) guayaqui Schrottky Figures 4C, 14, 15

Megachile guayaqui Schrottky, 1913: 171 (neotype + [here designated], NCSU 0021932: Nova Teutonia, Santa Catarina, Brazil). Moure et al., 2007: 991 (placement in Rhyssomegachile Mitchell).

DiAgnosis: This species is known only from the female sex and can be easily distinguished by the strong carina along the entire preoccipital margin (fig. 15C, D) (present only behind the gena in all other species of the subgenus). The dorsum of the mesosoma with long $(\geq 2.0 \times \mathrm{OD})$, light reddish-brown setae contrasting with the remaining whitish pubescence of the body, as well as the yellowish wings with yellow to light brown veins, are also distinctive features that distinguish this species from all other Rhyssomegachile.

Redescription: Female: total body length $11.9 \mathrm{~mm}$; forewing length $7.8 \mathrm{~mm}$; head width $3.6 \mathrm{~mm}$. Head $1.2 \times$ wider than long; intertorular distance $1.5 \times$ torulorbital distance; interocellar distance $2.2 \times \mathrm{OD}, 0.9 \times$ ocellocular distance; ocelloccipital distance $2.7 \times$ OD, $1.1 \times$ ocellocular 


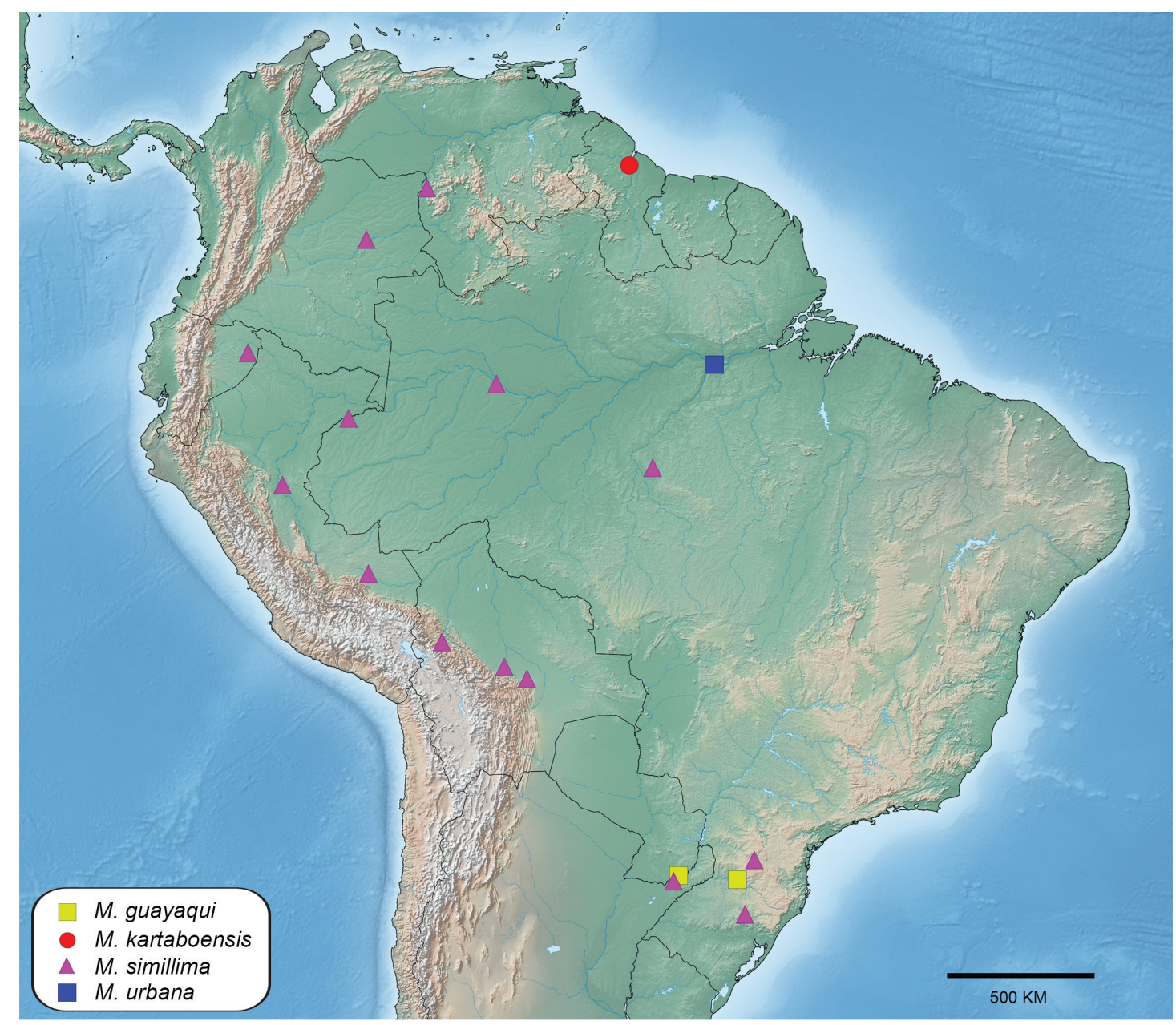

FIGURE 14. Collection localities for species of Megachile (Rhyssomegachile).

distance; clypeus with distal margin entire, slightly incurved medially; scape $3.6 \times$ longer than broad, pedicel about as long as $F 1$, each $1.1 \times$ longer than broad, F2 about as long as broad, slightly longer than F1, F3-F9 longer than broad, distalmost flagellomere longest, $1.8 \times$ longer than broad; carina behind gena continuing onto vertex. Metatibia 3.2x longer than broad; metabasitarsus $2.8 \times$ longer than broad, shorter $(0.8 \times)$ and narrower $(0.9 \times)$ than metatibia.

Body color black, except dark reddish brown on antennae, legs, and basal sterna. Tegula light reddish brown; wings yellowish; veins and pterostigma yellow to light brown.
Head and mesosoma with pubescence largely white, except: brownish gray to dark brown on clypeus, supraclypeal area, and outer surfaces of tibiae and tarsi; light reddish brown on dorsum of mesosoma (setae $\geq 2.0 \times \mathrm{OD}$ ). T1-T5 each with yellow to light reddish-brown apical fasciae, discs of T1-T3 with scattered, semierect dark reddish-brown setae, discs of T4-T6 with yellow to light reddish-brown appressed setae from which unbranched, scattered, erect to semierect setae arise; sternal scopa white except dark brown setae on sides of S3-S5 and S6 apically. Ventral surface of mesepisternum and legs without modified setae. 

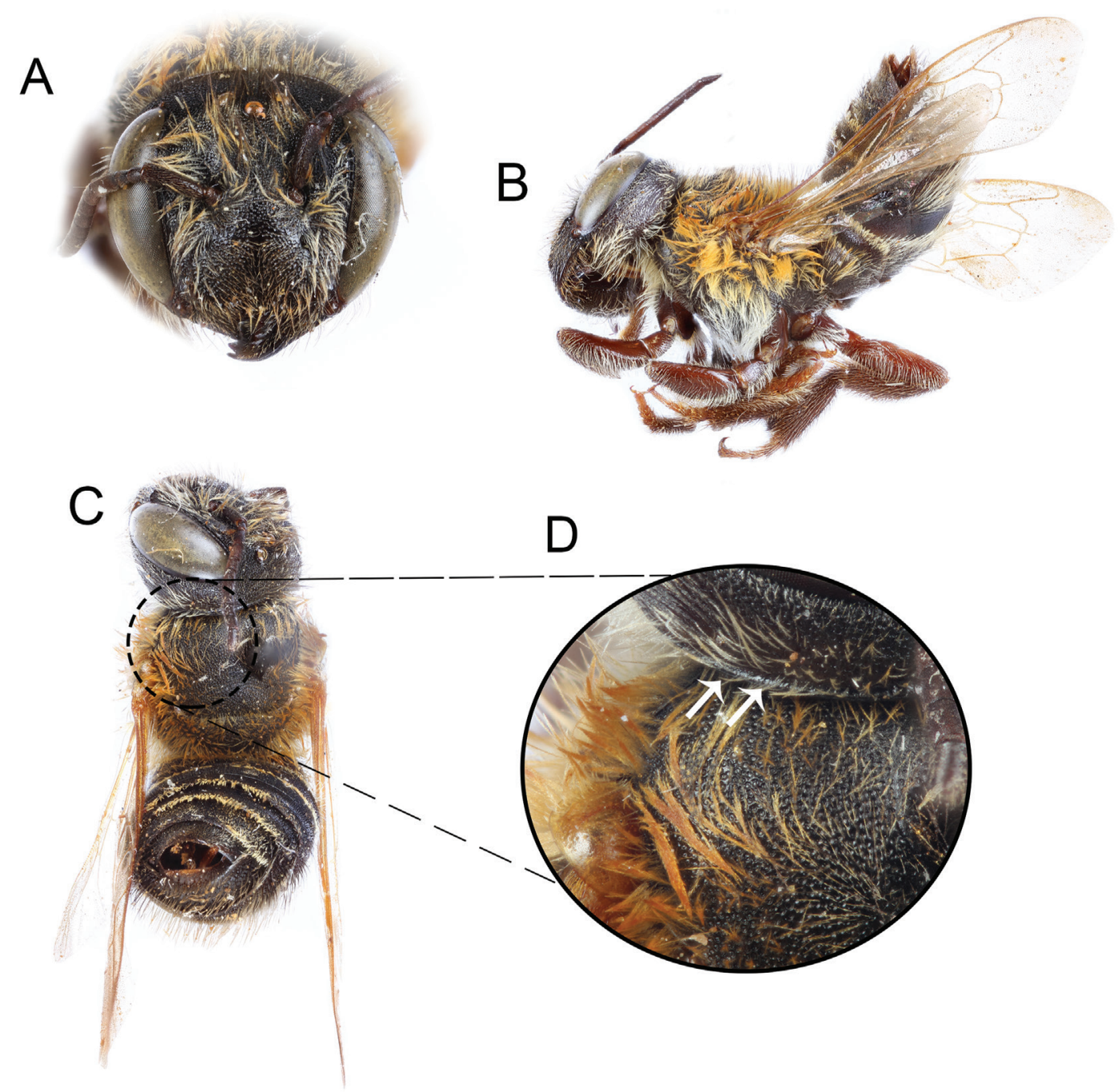

FIGURE 15. Female neotype of Megachile (Rhyssomegachile) guayaqui Schrottky. A. Facial view. B. Lateral habitus. C. Dorsal habitus. D. Detail of the left anterolateral area of mesoscutum and gena with arrows pointing to the carinate preoccipital margin.

Face and vertex coarsely and contiguously punctate, except discs of clypeus and supraclypeal area with sparser punctures (1.0-3.0x PW), surface among punctures angular on frons, rounded otherwise; gena with shallower, sparser punctures than on vertex, punctures stronger and closer on lower gena and hypostomal area; outer surface of mandible with carinae faintly imbricate, nearly smooth and shiny. Pronotum strongly imbricate with contiguous, smaller, shallower punctures than on mesoscutum; mesoscutum and mesoscutellum imbricate with coarser and larger punctures than on vertex, spaced $(\leq 0.5 \times \mathrm{PW})$; axilla with contiguous, smaller punctures than on mesoscutum; mesepisternum weakly imbricate with larger $(1.5 \times)$, sparser $(\leq 1.0 \times \mathrm{PW})$ punctures than on mesoscutum, punctures becoming smaller and closer dorsally; metepisternum and propodeum imbricate, with oval, faint, and spaced $(\leq 1.0 \times \mathrm{PW})$ 
punctures on metepisternum, about as large as those on mesepisternum dorsally; lateral surface of propodeum mostly with small, widely separated (2.0-4.0× PW) punctures; legs weakly imbricate to smooth and shiny, coarsely and densely $(\leq 1.0 \times \mathrm{PW})$ punctate, punctures larger and sparser on hind legs. Terga weakly imbricate, minutely and densely punctate, punctures separated by $1.0-2.0 \times$ a puncture width on discs, closer on apical terga; sterna strongly imbricate, coarsely punctate, punctures smaller and closer on basal sterna.

Male: Unknown.

NeOtype (here designated): $q$, Brazil, Nova Teutonia, S. Catharina, F. Plaumann, Dec 6, 1939/M. (subgenus?) guayaqui Schr. as det. 1982, in T.B. Mitchell collection/Megachile guayaqui Schr. det. J.S. Moure, 1957/NCSU 0021932/ 9 Neotype Megachile guayaqui Schrottky, Des. V.H. Gonzalez, M.S. Engel, \& T. Griswold 2016 (NCSU). Schrottky (1913) described this species from a female specimen from Hohenau, Itapúa, Paraguay. The type of this species, as many others described by C. Schrottky, is likely lost (Rasmussen et al., 2009). Thus, to stabilize this name, we here designate as neotype a female specimen collected 20 years after Schrottky's description in Nova Teutonia, Brazil, about $300 \mathrm{~km}$ west from the type locality. Although this specimen is not from the type locality, it was determined by J.S. Moure as M. guayaqui in 1957 and matches Schrottky's original description.

ADDITIONAL MATERIAL EXAMINED $(n=$ 13 우 ): Brazil: 1 옹 Santa Caterina, Nova Teutonia, Brazil, XI-1951, L.E. Plaumann/SEMC 1178592 (SEMC); 2 $q$, ut supra, S. Catharina, F. Plaumann, Dec 6 1939/NCSU 0021933, -34 (NCSU); 8 우, ut supra, Dec 81 1939/NCSU 0021935-41, 0021944 (NCSU); 1 , ut supra, Dec 7 1939/NCSU 0021942 (NCSU); 1 오, Brasilien, Nova Teutonia, $27^{\circ} 11^{\prime} \mathrm{B}, 52^{\circ} 23^{\prime} \mathrm{L}$, Fritz Plaumann, 25-11-1936/NCSU 0021943 (NCSU).

Distribution: In addition to the type locality in Paraguay, Moure et al. (2007) list this species from the states of Paraná and Santa Catarina, Brazil.

\section{Megachile (Rhyssomegachile) kartaboensis Mitchell}

Figure 4D, E, 14, 16

Megachile kartaboensis Mitchell, 1930: 299 (holotype + , examined, MCZ 16212: Kartabo, Guyana). Raw, 2002: 33 (placement in Rhyssomegachile Mitchell).

Diagnosis: This species is known only from the female holotype. It can be easily recognized by the following combination of features: preoccipital carina behind gena only; mesoscutum with contiguous punctures on disc; and ventral surface of mesepisternum and outer surfaces of pro- and mesotibiae and basitarsi covered with corkscrewlike setae (fig. 4D, E). It shares with $M$. simillima the mesoscutum contiguously punctate, but it can be distinguished by its larger body size, the corkscrew-like setae on the ventral surface of mesepisternum and fore- and middle legs (setae thick and apically curved in M. simillima), and finer punctation on clypeus and supraclypeal area. The corkscrewlike setae on the ventral surface of the mesepisternum and outer surfaces of the pro- and mesotibiae and basitarsi are also present in M. urbana. However, in that species the punctures on the disc of the mesoscutum are distinctly spaced, not contiguous, separated by $1-2 \times$ a puncture width.

REDESCRIPTION: Female: total body length 10.9 $\mathrm{mm}$; forewing length $8.8 \mathrm{~mm}$; head width 4.1 $\mathrm{mm}$. Head 1.3× wider than long; inner orbits of compound eyes parallel or nearly so; intertorular distance $1.4 \times$ torulorbital distance; interocellar distance $1.3 \times$ OD, $0.7 \times$ ocellocular distance; ocelloccipital distance $2.1 \times$ OD, $1.1 \times$ ocellocular distance; clypeus with distal margin entire, slightly incurved medially; scape $3.2 \times$ longer than broad, pedicel $1.2 \times$ longer than broad, F1 about as long as F2, slightly broader than long as in F2-F9, distalmost flagellomere longest, $1.6 \times$ longer than broad. Mesobasitarsus slightly broader and shorter than mesotibia; metatibia $2.9 \times$ longer than broad; metabasitarsus $2.8 \times$ longer than broad, shorter $(0.8 \times)$ and narrower $(0.9 \times)$ than metatibia. 
Body color black, except dark reddish brown on legs and basal sterna. Wings brownish, darker on radial cell apically, first submarginal, and marginal cells; veins and pterostigma dark brown.

Pubescence brownish gray to dark brown, except white on: paraocular area inferiorly, sides of clypeus and supraclypeal area, base of mandible, gena, hypostomal area, anterior margin of mesoscutum, distal margin of mesoscutellum, metanotum, sides of mesepisternum, metepisternum, propodeum, and S2-S5 except laterally. Ventral surface of mesepisternum and fore- and middle legs with coxae, trochanters, base of femora, and outer surfaces of tibiae and basitarsi densely covered by corkscrewlike setae. Discs of T2-T5 sparsely covered with short $(\sim 0.3 \times \mathrm{OD})$, appressed setae, laterally and on discs of T4 and T5 with scattered, erect or semierect setae; T6 with shorter, denser appressed setae, without erect setae.

Face and vertex coarsely and contiguously punctate with surface among punctures angular, except clypeus and supraclypeal area with finer, sparser $(\leq 1.0 \times \mathrm{PW})$ punctures, surface among them rounded, with integument smooth and shiny; gena with shallower punctures than on vertex, punctures stronger and closer on lower gena and hypostomal area; outer surface of mandible apically, above outer ridge, with carinae somewhat dull, minutely roughened. Pronotum weakly imbricate with smaller, shallower, sparser $(\leq 1.0 \times \mathrm{PW})$ punctures than on mesoscutum; mesoscutum, mesoscutellum as on vertex; axilla dorsally with integument weakly imbricate among sparser punctures than on mesoscutellum; mesepisternum smooth and shiny with larger $(1.5 \times)$, sparser $(\leq 1.0 \times \mathrm{PW})$ punctures than on mesoscutum, punctures becoming smaller and closer dorsally; metepisternum and propodeum imbricate, with oval, faint, and spaced $(\leq 1.0 \times \mathrm{PW})$ punctures on metepisternum, about as large as those on mesoscutum; lateral surface of propodeum with smaller, fainter, closer punctures than on metepisternum, posterior surface of propodeum with widely separated (2.0-4.0x PW) punctures; metanotum finely and minutely $(\leq 1.0 \times \mathrm{PW})$ punctate; legs weakly imbricate to smooth and shiny, coarsely and densely $(\leq 1.0 \times$ PW) punctate, punctures larger and sparser on hind legs. Terga minutely and densely punctate, punctures contiguous on discs, slightly spaced laterally, at most half a puncture width of those on mesoscutum, integument otherwise weakly imbricate to smooth and shiny; sterna strongly imbricate, coarsely punctate, punctures smaller and closer on basal sterna.

Male: Unknown.

Holotype: + , Kartabo, B.G., Jul, Aug. 1920, W.M. Wheeler/MCZ-ENT 00016212/Megachile kartaboensis Mitchell o, Type 16212 (MCZ).

\section{Megachile (Rhyssomegachile) simillima Smith}

Figures 1, 4A, 14, 17-19

Megachile simillima Smith, 1853: 185 (holotype , examined, BMNH 17A.2456: Pará, Brazil). Moure et al., 2007: 991 (placement in Rhyssomegachile Mitchell).

Megachile cara Mitchell, 1930: 263 (neotype o

[here designated], NCSU 0020754:

Buenavista, Bolivia). Mitchell, 1943: 668

(placement in Ptilosarus Mitchell).

Megachile stabilis Mitchell, 1930: 298 (neotype 우

[here designated], NCSU 0005853:

Buenavista, Bolivia). Raw, 2002: 33 (place-

ment in Rhyssomegachile Mitchell).

Diagnosis: The female of this species can be easily recognized by the following combination of features: preoccipital carina behind gena only; mesoscutum with contiguous punctures on disc, surface among punctures angular (fig. 4A); ventral surface of mesepisternum and fore- and middle legs with coxae, trochanters, femora, and outer surfaces of tibiae and basitarsi covered by thick, minutely branched, and apically curved setae (fig. 17C); T2-T5 each with apical fasciae at least laterally (fig. 17E); T6 covered mostly by short, appressed yellowish setae from which scattered, longer, erect setae arise. The male can be recognized by following combination of features: mesoscutum imbricate, with contiguous or 

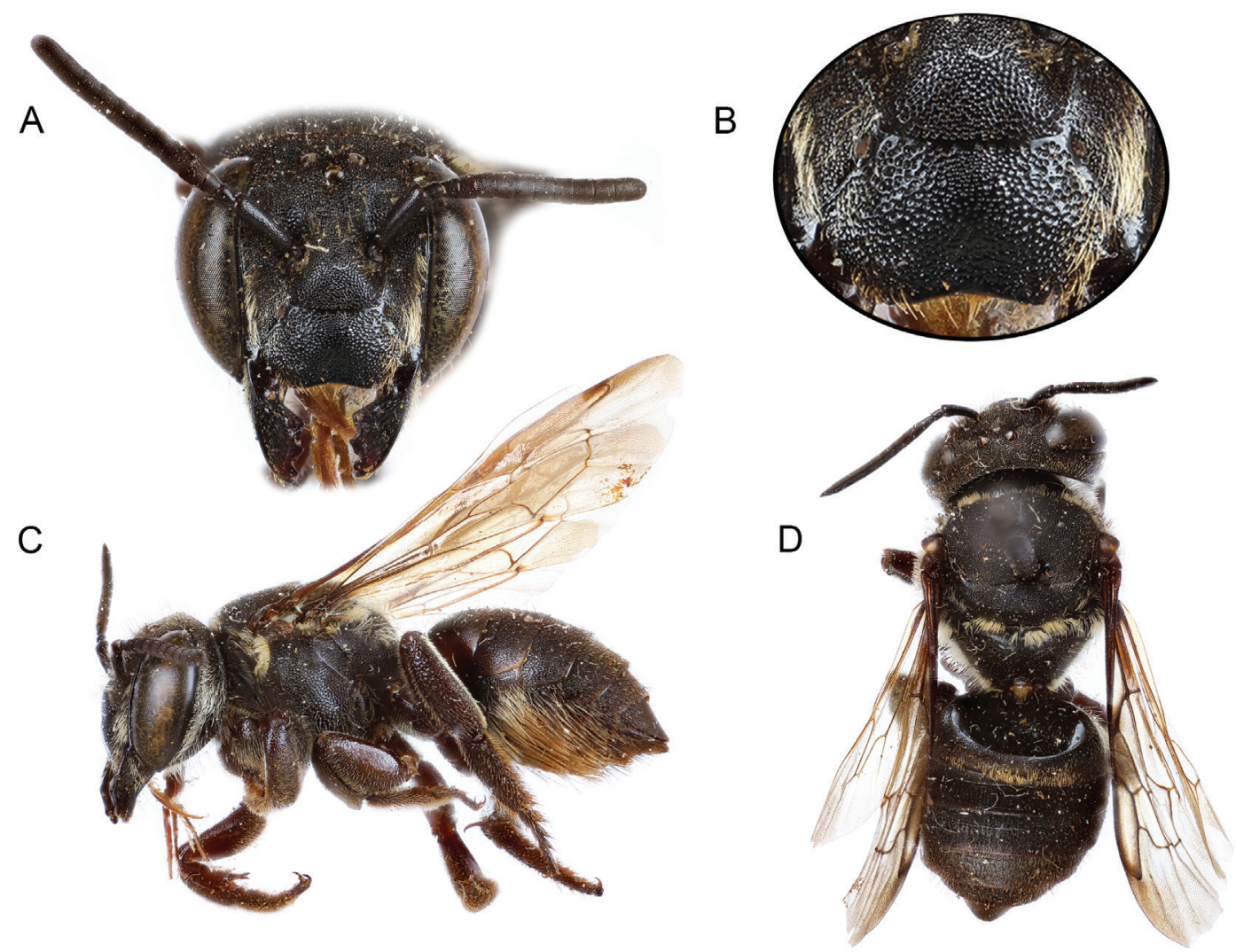

FIGURE 16. Female holotype of Megachile (Rhyssomegachile) kartaboensis Mitchell. A. facial view. B. Detail of clypeus and supraclypeal area. C. Lateral habitus. D. Dorsal habitus.

nearly so, coarse punctures on disc; procoxa without spine; metafemur without a keirotrichial patch on its posterosuperior surface; metabasitarsus elongate, about $3.7 \times$ longer than broad, with short setae along its anterior margin, at most as long as maximum basitarsal width. The female of this species resembles that of M. kartaboensis in the coarse, contiguous punctation of the mesoscutum. It can be distinguished from that species by its smaller body size, the ventral surface of the mesepisternum and fore- and middle legs covered by thick, apically curved setae (corkscrew-like setae covering these structures in M. kartaboensis), and the coarser punctation on the clypeus and supraclypeal area. Also, the interocellar area is greater in M. simillima $(2.1 \times$ OD) than in M. kartaboensis (1.3× OD).
REDESCRIPTION: Female: total body length 9.3 $\mathrm{mm}$; forewing length $6.9 \mathrm{~mm}$; head width 3.3 $\mathrm{mm}$. Head $1.3 \times$ wider than long; inner orbits of compound eyes parallel or nearly so; intertorular distance $1.6 \times$ torulorbital distance; interocellar distance $2.1 \times \mathrm{OD}$, slightly shorter than ocellocular distance; ocelloccipital distance $2.6 \times \mathrm{OD}$, $1.2 \times$ ocellocular distance; clypeus with distal margin sinuous, slightly incurved medially; scape $3.2 \times$ longer than broad, pedicel slightly longer than broad, F1 about as long as F2, slightly broader than long as in F2-F9, distalmost flagellomere longest, $1.5 \times$ longer than broad. Mesobasitarsus narrower, shorter than mesotibia; metatibia $2.4 \times$ longer than broad; metabasitarsus $2.9 \times$ longer than broad, shorter $(0.7 \times)$ and narrower $(0.9 \times)$ than metatibia. 


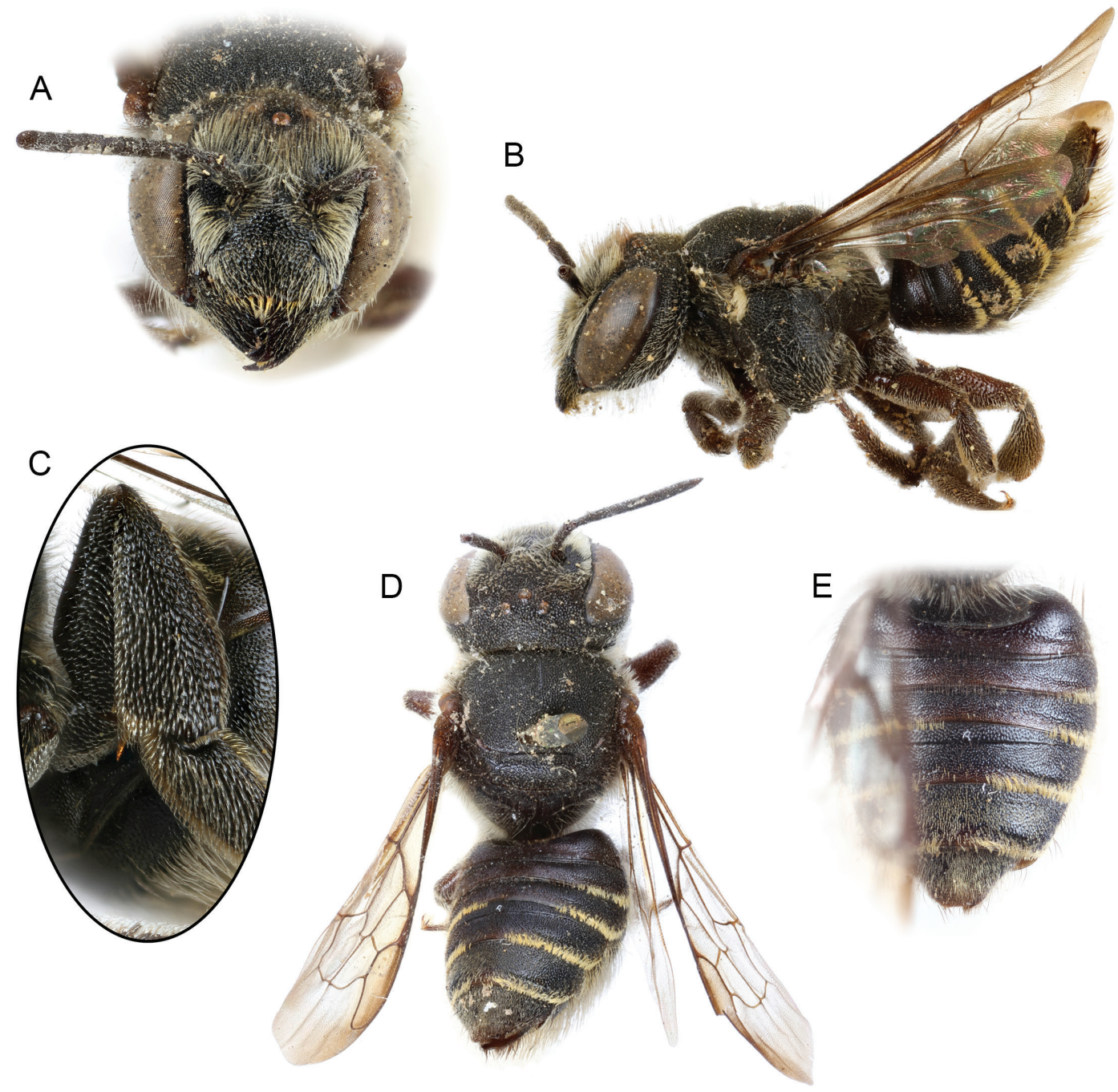

FIGURE 17. Female holotype of Megachile (Rhyssomegachile) simillima Smith, except figure C (Colombia: Amazonas, SEMC 1184307). A. Facial view. B. Lateral habitus. C. Outer Surface of posterior leg showing modified setae. D. Dorsal habitus. E. Dorsal view of metasoma.

Body color black, except dark reddish brown on outer surface of mandible apically, legs, tegula, and basal sterna. Wings slightly brownish, darker on radial cell apically, first submarginal, and marginal cells; veins and pterostigma dark brown.

Pubescence predominantly white except: vertex, discs of mesoscutum and mesoscutellum, inner surfaces of tarsi, and S6 with brownish setae; discs of T1-T4 with short, dense, appressed, dark brown to black setae, discs of T5 and T6 with short, dense, appressed yellowish setae and longer, scattered, erect to semierect setae; apical margins of T2-T5 laterally with yellowish fasciae. Ventral surface of mesepisternum and all legs distinctly covered by thick, minutely branched, and apically curved setae.

Face and vertex coarsely and contiguously punctate with surface among punctures angular, except clypeus, supraclypeal area, and vertex with sparser $(\leq 0.5 \times \mathrm{PW})$ punctures, surface among 

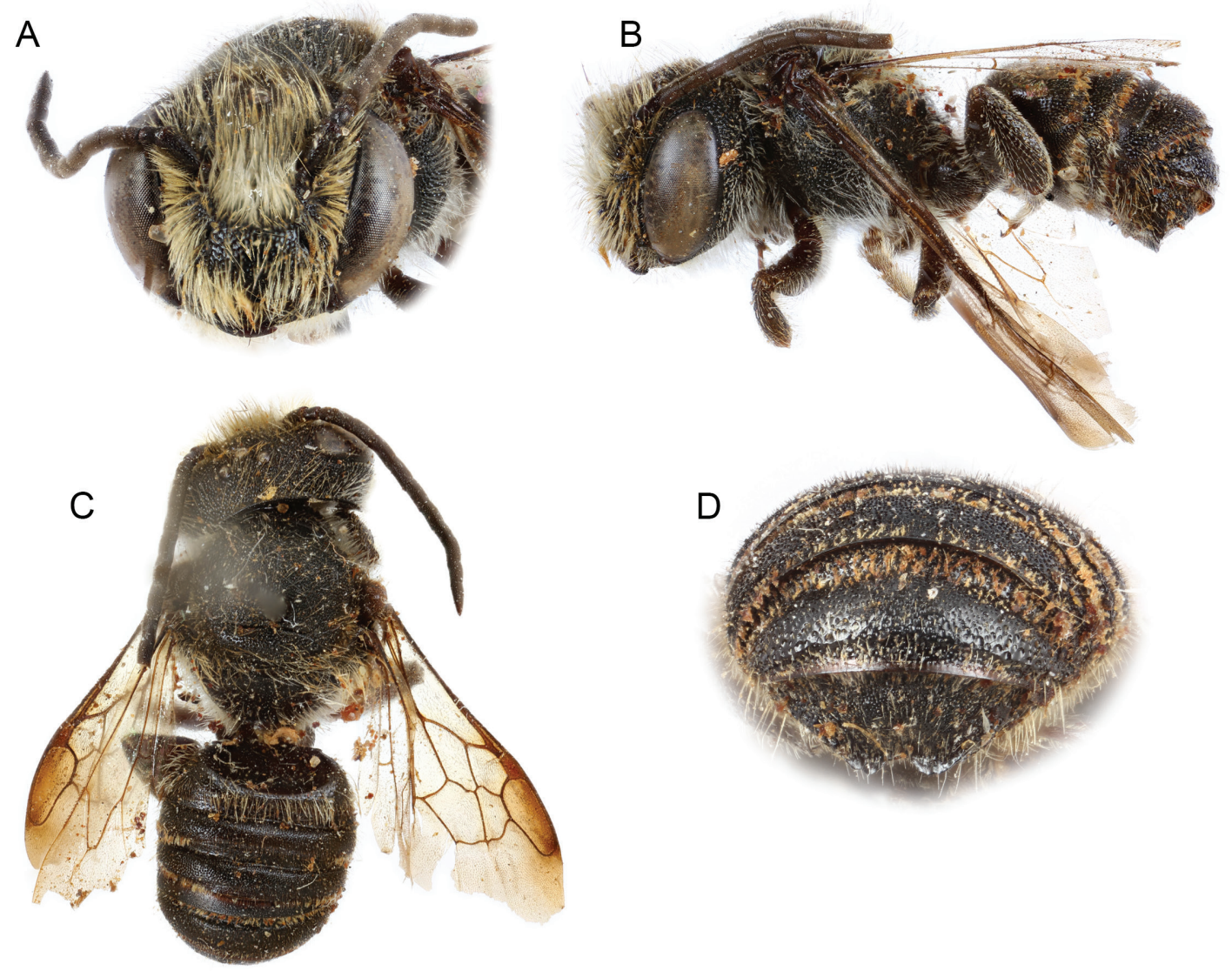

FIGURE 18. Male neotype of Megachile cara Mitchell, a junior subjective synonym of M. (Rhyssomegachile) simillima Smith. A. Facial view. B. Lateral habitus. C. Dorsal habitus. D. Dorsal view of T5 and T6.

them rounded, smooth and shiny; gena with shallower punctures than on vertex, punctures stronger, smaller, closer on lower gena and hypostomal area than on upper gena; outer surface of mandible apically, above outer ridge, with carinae smooth and shiny. Pronotum weakly imbricate with smaller, shallower, sparser $(\leq 1.0 \times \mathrm{PW})$ punctures than on mesoscutum; mesoscutum as on frons; discs of mesoscutellum and axilla with sparser punctures than on mesoscutum, surface among them rounded; mesepisternum smooth and shiny with larger $(1.5 \times)$, sparser $(\leq 1.0 \times \mathrm{PW})$ punctures than on mesoscutum, punctures becoming smaller and closer dorsally; metepisternum and propodeum imbricate, with oval, faint, and spaced $(\leq 1.0 \times \mathrm{PW})$ punctures on metepister- num, about as large as those on mesoscutum; lateral surface of propodeum with smaller, closer, fainter punctures than on metepisternum, posterior surface of propodeum with widely separated (2.0-4.0× PW) punctures, propodeal triangle strongly imbricate to minutely rugulose; metanotum minutely rugulose with small, scattered (2.0$3.0 \times$ PW) punctures; legs weakly imbricate to smooth and shiny among coarse, dense $(\leq 1.0 \times$ PW) punctures, punctures sparser on femora. Terga weakly imbricate to smooth and shiny, with smaller (0.5×), sparser (1.0-2.0× PW) punctures than mesoscutum, punctures most sparse on disc of $\mathrm{T} 1$, denser on apical terga; sterna strongly imbricate, coarsely punctate, punctures smaller and closer on basal sterna. 

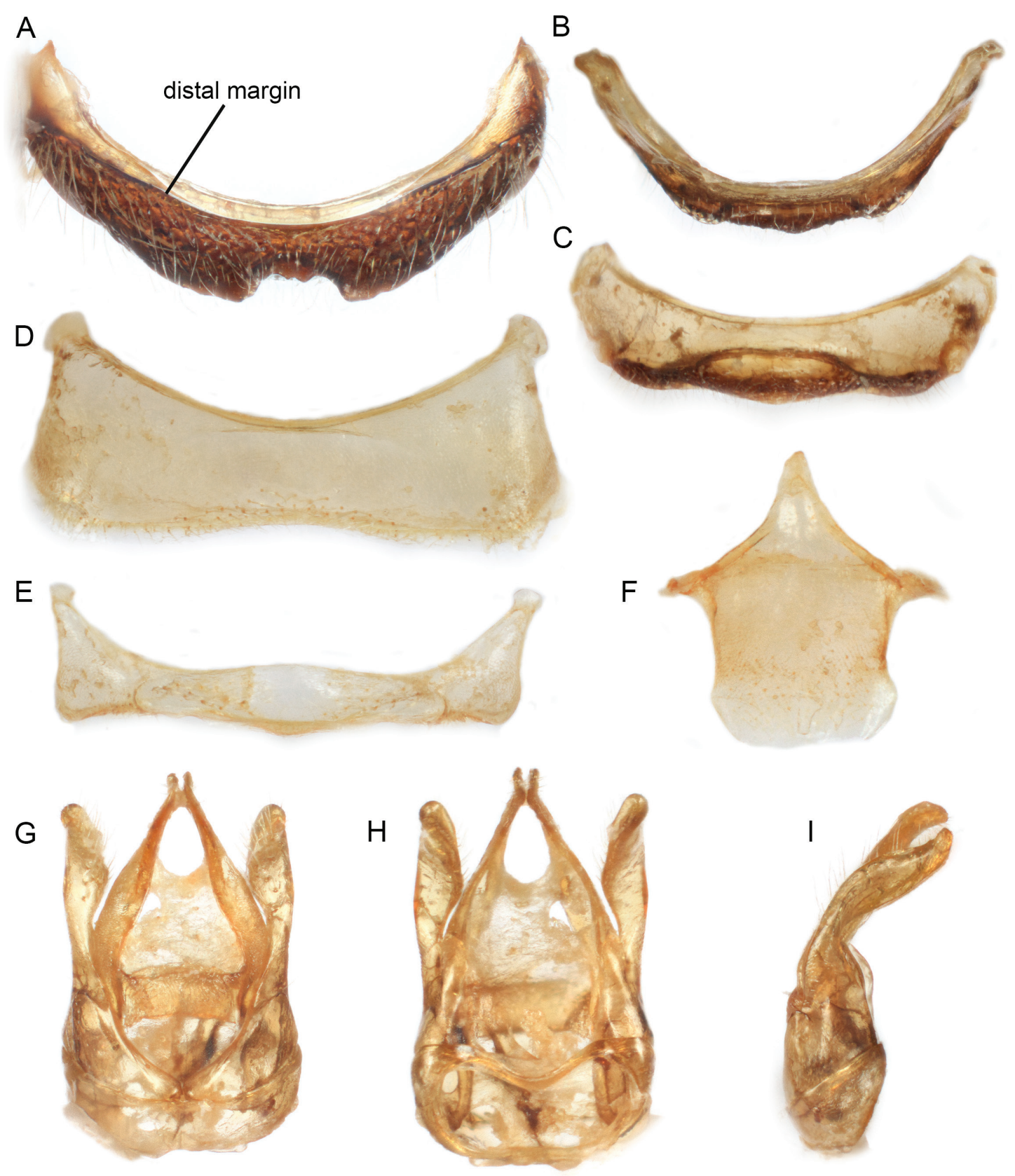

FIGURE 19. Male of Megachile (Rhyssomegachile) simillima Smith (Brazil, Acre, SEMC 1205353). A. Sixth tergum, inner view. B, C. Seventh tergum in dorsal and ventral views. D. Fifth sternum. E. Sixth sternum. F. Eighth sternum. G-I. Genital capsule in dorsal, ventral, and lateral views. 
Male: As described for the female except for the usual secondary sexual characters and the following: total body length $8.0 \mathrm{~mm}$; forewing length $6.3 \mathrm{~mm}$; head width $3.1 \mathrm{~mm}$. Inner orbits of compound eyes converging below; intertorular distance $2.2 \times$ torulorbital distance; interocellar distance $1.8 \times \mathrm{OD}$, shorter $(0.8 \times)$ than ocellocular distance; ocelloccipital distance $2.3 \times \mathrm{OD}$, about as long as ocellocular distance; scape $2.1 \times$ longer than broad, pedicel about as long as F1, each about as long as broad, F2 1.5× longer than F1, longer than broad as remaining flagellomeres, distalmost flagellomere longest, apically flattened, not expanded. Procoxa unmodified, without spine; metafemur without a keirotrichial patch on its posterosuperior surface; metabasitarsus elongate, about $3.7 \times$ longer than broad. T6 with preapical carina sometimes weakly crenulated. Genital capsule and associated terga and sterna as in figure 19.

Pubescence longer and denser than the female; clypeus sparsely covered by setae (integument largely visible among setae) on basal two thirds, densely covered by setae (integument not visible among setae) on apical one third. Meso- and metabasitarsus with short setae along anterior margin, at most as long as maximum basitarsus width.

Punctation coarser than in female; T4 and T5 with depressed, smooth, shiny, brown apical margins.

Holotype (M. simillima): ㅇ, Type/5/4/ ? [illegible]/ B.M. Type Hym. 17a.2456/ simillima Type $\mathrm{Sm} /$ Megachile simillima Type. Sm. (BMNH). The holotype of M. simillima is in relatively good condition, except for some hyphae sparsely covering the head and mesosoma, left F1-F6 missing, and T6 and S6 slightly pushed inside the metasoma.

Neоtype ( $M$. cara, here designated): $\delta$, Buenavista, Dep. Sta. Cruz, Bolivia, 450 m.h./ QR barcode NCSU 0020754/ o Megachile cara Mitchell, Paratype (greenish label)/ ô Neotype Megachile cara Mitchell, Des. V.H. Gonzalez, M.S. Engel, \& T. Griswold 2016 (NCSU). Megachile cara Mitchell was described from three male specimens whereas M. stabilis Mitchell from six female specimens, all from the same locality. The holotypes of both species were lost during World War II (see Material and Methods, above), and to stabilize these names, we herein designate as neotypes one of the paratypes of each species.

Neotype (M. stabilis, here designated): $q$, Buenavista, Dep. Sta. Cruz, Bolivia, 450 m.h. / (Rhyssomegachile) simillima Sm. as det. 1982 in T.B. Mitchell collection/QR barcode NCSU 0005853/Megachile stabilis Mitchell, Paratype/ $q$ Neotype Megachile stabilis Mitchell, Des. V.H. Gonzalez, M.S. Engel, \& T. Griswold 2016 (NCSU). See above (neotype for M. cara) for discussion of type series for M. stabilis.

AdDitional material EXAMined $(n=$ $26 \hat{\delta} \hat{o}, 78 ㅇ ㅜ$ ): Argentina: 1 , Arg. [Argentina], Misiones, Puerto Esperanza, Fritz, XII.76 [December, 1976] (AMNH). Bolivia: 1 오 Bolivia, Guanay, Uyapi-X-95, Gerlach/AMNH_ BEE 000210951 (AMNH); 19 , Bolivia: La Paz Prov. Uyapi/Guanay, Nov. 1998, A. Ugarte Peña (AMNH); 1 ㅇ, La Paz: Guanay, 10-XI-1992, Luis Peña/AMNH_BEE 00021096 (AMNH); 19 , Buenavista, Dep. Sta. Cruz, Bolivia, 450 m.h./NCSU 0005852/Megachile stabilis Mitchell, Paratype (NCSU);1 $q$, Bolivia-Pto. Fon Beni, Beni, 12 Nov. 1956 (L. Pena)/SEMC 1204252 (SEMC). Brazil: $29+9$, Acre, Iquiri, 24 August 1951/SEMC 1205351, -57 (SEMC); 9 우 우, 3 춯, Tefé, Amazonas, Brasil, IX-1959, R. Carvalho/ Coleção Campos Seabra/NCSU 0004708-16, 0020755, -57, -58, (NCSU); 1 के, ut supra, VIII1959/NCSU 0020756 (NCSU); 19 호, Brasil, Rio Jaravi, Estirao do Equador [Amazonas], Alvarenga, X.79 [1979] (AMNH); 5 우, Jacareacanga, Pará, Brasil, X-1959, M. Alvarenga leg./NCSU 0004723-27; 1 \% , ut supra, July 1969, F. Barbosa (AMNH); 1 , Brasil: Paraná, Bituruna, 25-30 Jan 1956, V. Stawiarski/SEMC 1205299 (SEMC); 2 우, Porto Cabral, Rio Paraná, Travassos Filho o. [Brazil]/NCSU 0004721, -22/(NCSU); 19 , ut supra (AMNH); 24 ㅇ ㅇ , Brasil: Guapore, Abunã, Nov. 62 (W. Bokermann)/SEMC 1184304-05, 1204881-83, 1204886, 1204887, 1204889, 1204890, 1204900, 
1204901, 1204907, 1204908, 1204910-14, 1204916-19, 1204921, 1204923 (SEMC); 4 우, 10, Porto Velho, Guaporé, Brasil, XI-1954, M. Alvarenga, Dente, F. Pereira e Werner/Coleção Campos Seabra/SEMC 1178755-58 (SEMC); $9 q+10$, ut supra, NCSU 0004399, 0004400, 0004701-07, 0020759 (NCSU); $3 q+$, Sao Carlos, Matto Grosso, Porte Velhos, Brazil, Sep. 9 1943, Mark Taylor/NCSU 0004718-20 (NCSU); $1+$, Mato Grosso: Sinop, October 1976, M. Alvarenga/AMNH_BEE 00021097 (AMNH); 1 , , St. Paulo/NCSU 0004728 (NCSU); 1 , 56 43/NCSU 0004398 (NCSU). Colombia: 1 우, Colombia, Amazonas, Parque Nacional Natural Amacayacu, at junction of Matamata stream with Rio Amazonas, F. Fernandez/ AM 7-13/ CM 177/SEMC 1184310 (SEMC); 3 우, ut supra, $2 \mathrm{~km}$ above mouth Rio Amazonas, 4 October 1998, Fernando Fernandez/ SEMC 1184307-09 (SEMC). Ecuador: 1 ㅇ, Ecuador, Napo Prov., Yasuni National Park, Est. La Catolica; Nov. 7-15, 1998, DRoubik No. 83 (BBSL). Peru: $3 q q, 10$, Peru, Madre de Dios, Pakitza Bio. Sin., Reserved Zone, Manu National Park, $317 \mathrm{~m}, 11^{\circ} 56^{\prime} 41^{\prime \prime} \mathrm{S}, 71^{\circ} 17^{\prime} 0^{\prime \prime} \mathrm{W}, 16$ Oct 2000 ; R. Brooks, PERU 1 B00 008, ex: wet area near stream/SM0255992, 0256004, 0256014, 0255775 (SEMC); 1 , , Madre de Dios: Loromayo, on Inambari R., in low forest area, IX-10-1962/L.E. Pena collector (AMNH); $3 q q$, Middle Rio Ucayali, Peru, X-27-23 [October 27, 1923], F6116/H. Bassler Collection, Acc. 33591 (AMNH); 2 우, ut supra, XII-8-24 [December 8, 1924], F6174 (AMNH). Venezuela: $2 q q$, Venezuela, Terr. Federal Amazonas, Rio Cantaniapo at Las Paras/23 January 1989, J.T. Polhemus, \#CL2377/ex. wet sand seeps/SEMC 1184311-12 (SEMC).

Distribution: Argentina (Misiones), Bolivia (La Paz, Santa Cruz), Brazil (Pará, Rio Grande do Sul), Colombia (Amazonas), Ecuador (Napo), Peru (Madre de Dios), Venezuela (Amazonas) (fig. 14). This species appears to occur primarily in tropical rainforests and thus records from Mendoza, Argentina (Moure et al., 2007) need to be confirmed.

\section{Megachile (Rhyssomegachile) urbana Smith}

Figure 14, 20

Megachile urbana Smith, 1879: 76 (lectotype + , examined, BMNH 17A.2451: Santarém, Pará, Brazil).

Diagnosis: This species is known only from the female lectotype. It shares with M. kartaboensis Mitchell a large body size (head width: 3.9$4.0 \mathrm{~mm}$ ), presence of carina behind gena only, short interocellar distance $(<1.5 \times \mathrm{OD})$, fine punctation on clypeus and supraclypeal area, absence of apical fascia on terga, and presence of corkscrew-like setae on the ventral surface of the mesepisternum and fore- and middle legs. It can be easily recognized from that species, as well as from $M$. simillima, by the punctation of the mesoscutum, which is sparsely punctate on the disc, with punctures separated by $1.0-2.0 \times$ a puncture width (fig. 20D).

Redescription: Lectotype, Female: total body length $11.5 \mathrm{~mm}$; forewing length $8.8 \mathrm{~mm}$; head width $4.0 \mathrm{~mm}$. Head $1.3 \times$ wider than long; inner orbits of compound eyes parallel or nearly so; intertorular distance $1.4 \times$ torulorbital distance; interocellar distance $1.5 \times \mathrm{OD}, 0.8 \times$ ocellocular distance; ocelloccipital distance $2.4 \times \mathrm{OD}$, $1.2 \times$ ocellocular distance; clypeus with distal margin entire, slightly incurved medially; scape $3.0 \times$ longer than broad, pedicel $1.2 \times$ longer than broad, F1 about as long as F2, slightly broader than long as in F2-F9, distalmost flagellomere longest, $1.6 \times$ longer than broad. Mesobasitarsus slightly broader and shorter than mesotibia.

Body color black, except dark reddish brown on legs, distal half of T1-T5, and sterna. Wings slightly brownish, darker on radial cell apically, first submarginal, and marginal cells; veins and pterostigma dark brown.

Pubescence brownish gray to dark brown, except white on: paraocular area inferiorly, sides of clypeus and supraclypeal area, base of mandible, gena, hypostomal area, anterior margin of mesoscutum, metanotum, sides of mesepisternum, metepisternum, propodeum, and S2-S5 

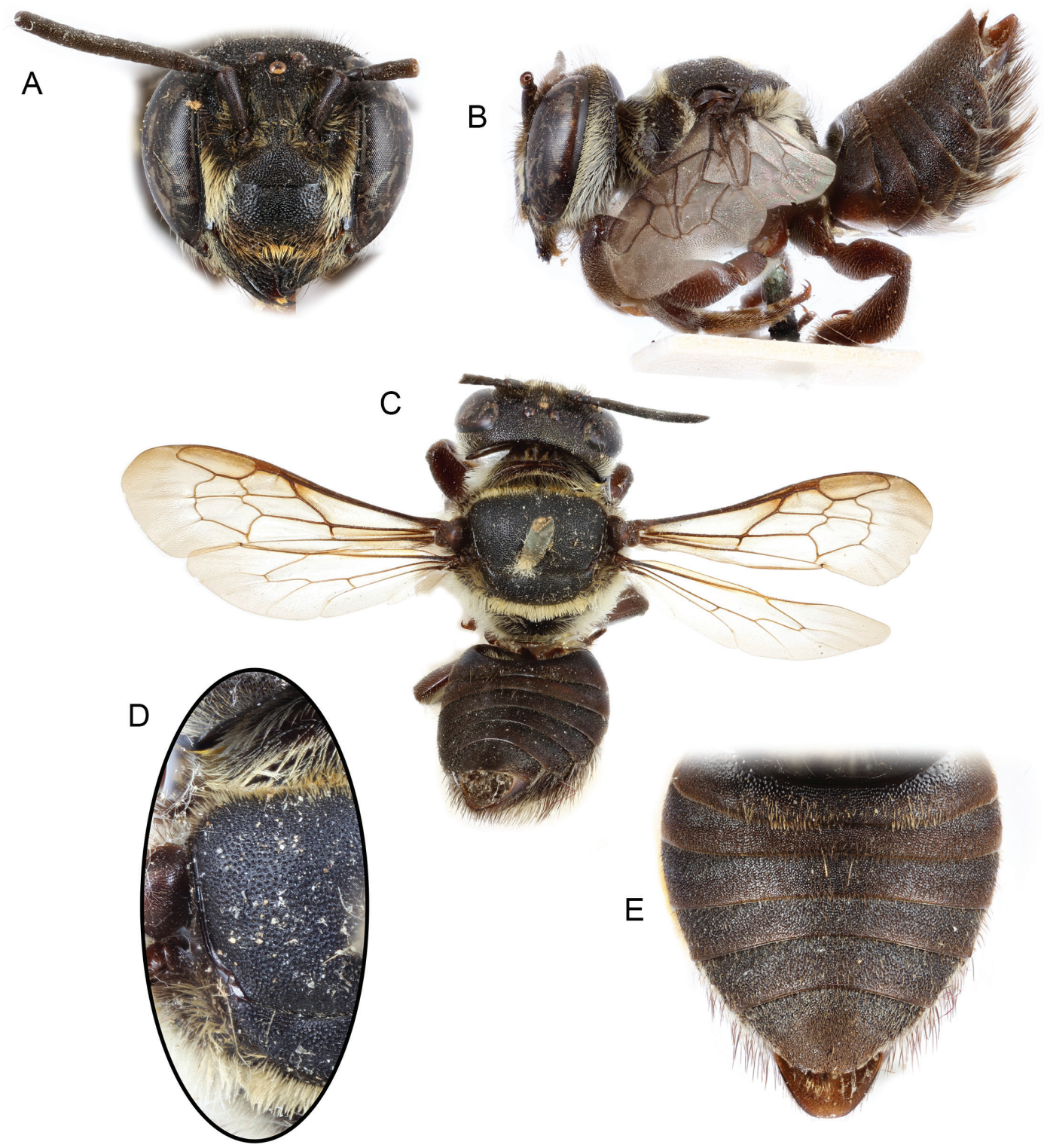

FIGURE 20. Female holotype of Megachile (Rhyssomegachile) urbana Smith. A. Facial view. B. Lateral habitus. C. Dorsal habitus. D. Detail of mesoscutum and mesoscutellum. E. Dorsal view of metasoma. 
except laterally. Ventral surface of mesepisternum and fore- and middle legs with coxae, trochanters, base of femora, and outer surfaces of tibiae and basitarsi densely covered by corkscrewlike setae (Fig. x). Discs of T2-T5 sparsely covered with short $(\sim 0.3 \times \mathrm{OD})$, appressed setae, laterally and on discs of T4 and T5 with scattered, longer, erect or semierect setae; T6 with shorter, denser appressed setae than on preceding terga, with scattered erect setae laterally.

Face and vertex coarsely and contiguously punctate, with surface among punctures angular on frons, rounded otherwise; clypeus and supraclypeal area smooth and shiny, with finer punctures than on vertex, punctures sparser $(\leq 1.0 \times$ PW) and larger on disc of clypeus; upper gena with shallower, smaller punctures than on vertex, punctures stronger and closer on lower gena and hypostomal area; outer surface of mandible apically, above outer ridge, with carinae somewhat dull, minutely roughened. Pronotum weakly imbricate with smaller, shallower punctures than on mesoscutum; mesoscutum weakly imbricate, somewhat dull, punctures separated by $1.0-2.0 \times$ a puncture width on disc, contiguous or nearly so along margins; mesoscutellum and axilla dorsally as on disc of mesoscutum; mesepisternum smooth and shiny with larger $(1.5 \times)$, sparser (1.0-1.5 $\times \mathrm{PW})$ punctures than on mesoscutum, punctures becoming smaller and closer dorsally; metepisternum and propodeum imbricate, with oval, faint, and spaced $(\leq 1.0 \times \mathrm{PW})$ punctures on metepisternum, about as large as those on mesoscutum; lateral surface of propodeum with smaller, fainter, closer punctures than on metepisternum, posterior surface of propodeum with widely separated (2.0-4.0× PW) punctures; metanotum finely and minutely $(\leq 1.0 \times \mathrm{PW})$ punctate; legs weakly imbricate to smooth and shiny, coarsely and densely $(\leq 1.0 \times \mathrm{PW})$ punctate, punctures larger and sparser on hind legs. Terga minutely and densely punctate, punctures contiguous or nearly so, at most separated by a puncture width; sterna strongly imbricate, coarsely punctate, punctures smaller and closer on basal sterna.
Male: Unknown.

Leстотуре: + , Sant-arem/Santarem/Type/ B.M. Type Hym. 17a.2451/Megachile urbana + , Type Sm./Lectotype + , det. J.S. Moure 1958 $(\mathrm{BMNH})$. The lectotype was designated by Moure in Moure et al. (2007).

Distribution: This species is currently known only from the type locality.

Comments: Megachile tricosa, a species described from a single male specimen and previously synonymized under M. urbana, is herein recognized in its own subgenus, Megachile (Aporiochile). For a discussion, see commentary section for that subgenus.

\section{Key to Species of Rhyssomegachile}

\section{Females}

1. Carina behind gena continuing onto vertex (fig. 15C, D); dorsum of mesosoma with long $(\geq 2.0 \times \mathrm{OD})$, light reddish-brown setae (fig. 15B, C); forewing yellowish with yellow to light brown veins (fig. 15B)

..M. guayaqui Schrottky

- Carina behind gena not continuing onto vertex; dorsum of mesosoma with shorter $(\geq 1.0 \times$ OD), yellowish or grayish setae; forewing brownish with dark brown veins ........2

2(1).Disc of mesoscutum with punctures distinctly spaced, not contiguous, separated by $1-2 \times$ a puncture width (fig. 20D)

..M. urbana Smith

- Disc of mesoscutum with punctures contiguous or nearly so (fig. 4A) 3

3(2).Ventral surface of mesepisternum and foreand middle legs with coxae, trochanters, base of femora, and outer surfaces of tibiae and basitarsi densely covered by corkscrewlike setae (fig. 4D, E); clypeus and supraclypeal area finely and densely punctate (fig. 16B); T2-T5 without apical fasciae (fig. 16D); T6 with short, appressed brownishgray setae, without longer, erect setae M. kartaboensis Mitchell 
- Ventral surface of mesepisternum and all legs distinctly covered by thick, minutely branched, and apically curved setae (fig. 17C); clypeus and supraclypeal area coarsely punctate (fig. 17A); T2-T5 each with apical fasciae at least laterally (fig. 17D, E); T6 covered mostly by short, appressed yellowish setae from which scattered, longer, erect setae arise M. simillima Smith

\section{Subgenus Zonomegachile Mitchell}

Figures 2, 4F, 5F, H, 21-34

Chrysosarus (Zonomegachile) Mitchell, 1980: 72. Type species: Megachile mariannae Dalla Torre, 1896 (= Megachile moderata Smith, 1879), by original designation. Michener, 2007: 585.

Diagnosis: Both sexes of this subgenus are superficially most similar to some species of Chrysosarus. The female of Zonomegachile can be distinguished by the presence of interdental laminae (fig. 2) in the mandible (absent or nearly so in Chrysosarus: fig. 3A), whereas the male may be recognized by the presence of the hypostomal projection (fig. 5F) (absent in Chrysosarus).

REDESCRIPTION: Moderate to large-sized bees (10.0-15.0 mm in body length). Integument weakly imbricate to smooth and shiny among spaced punctures. Preoccipital margin sharply angled.

Female: Mandible with four similarly sized and apically acute teeth, with large, incomplete interdental laminae in second and third interspaces, that of the second only slightly depressed below level of interspace margin, outer surface dulled by micropunctures (appearing imbricate at low magnifications), with coarse, dense punctures basally, carinae smooth and shiny (fig. 2); ocelloccipital distance at most as long as ocellocular distance. Metasoma ovoid, with white apical fasciae on $\mathrm{T} 1-\mathrm{T} 5$, without premarginal lines on T2-T5; sterna with apical fasciae beneath scopa, laterally on S2-S4, along entire margin on S5; S6 with well-dispersed scopal setae; T6 straight in profile, with abundant erect setae arising from decumbent pubescence.

Male: Antennal flagellum unmodified, F1 shorter than F2; mandible tridentate, without basal projection or tooth on lower margin; hypostomal area, behind base of mandible, strongly projected into an angle, hook, or protuberance (fig. 5F); procoxa with long apical spine; pro- and mesotibiae unmodified; protarsus slightly to moderately expanded posteriorly; mesotarsus unmodified; metafemur without a keirotrichial patch on its posterosuperior surface; metabasitarsus elongate, at least $2.5 \times$ longer than broad; mesotibial spur present, articulated to mesotibia, about as long as apical width of mesotibia. T6 with strong preapical carina, with a deep semicircular emargination medially, distal margin without a distinct tooth or projection; T7 preapically angled; S4 exposed, with punctation and vestiture similar to those of preceding sterna; S5 and S6 with postgradular areas distinctly setose; S8 without marginal setae. Genital capsule elongate, $1.8 \times$ longer than wide, robust; gonocoxite dorsally with low, broadly rounded lobe; gonostylus straight or nearly so in ventral view (gonostyli of M. moderata Smith in figures $30 \mathrm{E}-\mathrm{G}$ are distorted due to manipulation and thus appear medially directed), narrowest at midlength in lateral view, apically simple, unmodified, with exceptionally short setae along its medial margin except by apical tuft (absent in M. uncinata, n. sp.) of long setae (about as long as width of gonostylus); volsella present, apically rounded.

Distribution: Argentina, Bolivia, Brazil, Colombia, Ecuador, French Guiana, Peru (fig. 21).

Comments: We recognize eight species in this subgenus (table 1) some of which might be the unknown sex of others (refer to species accounts and discussion, below). Megachile moderata is the most widely distributed species, as it occurs from eastern Colombia to southern Brazil. Megachile uncinata is known from the male sex only and was included in this subgenus based on the presence of a hypostomal projection. However, the shape of the genital capsule and associated sterna does not suggest a close 


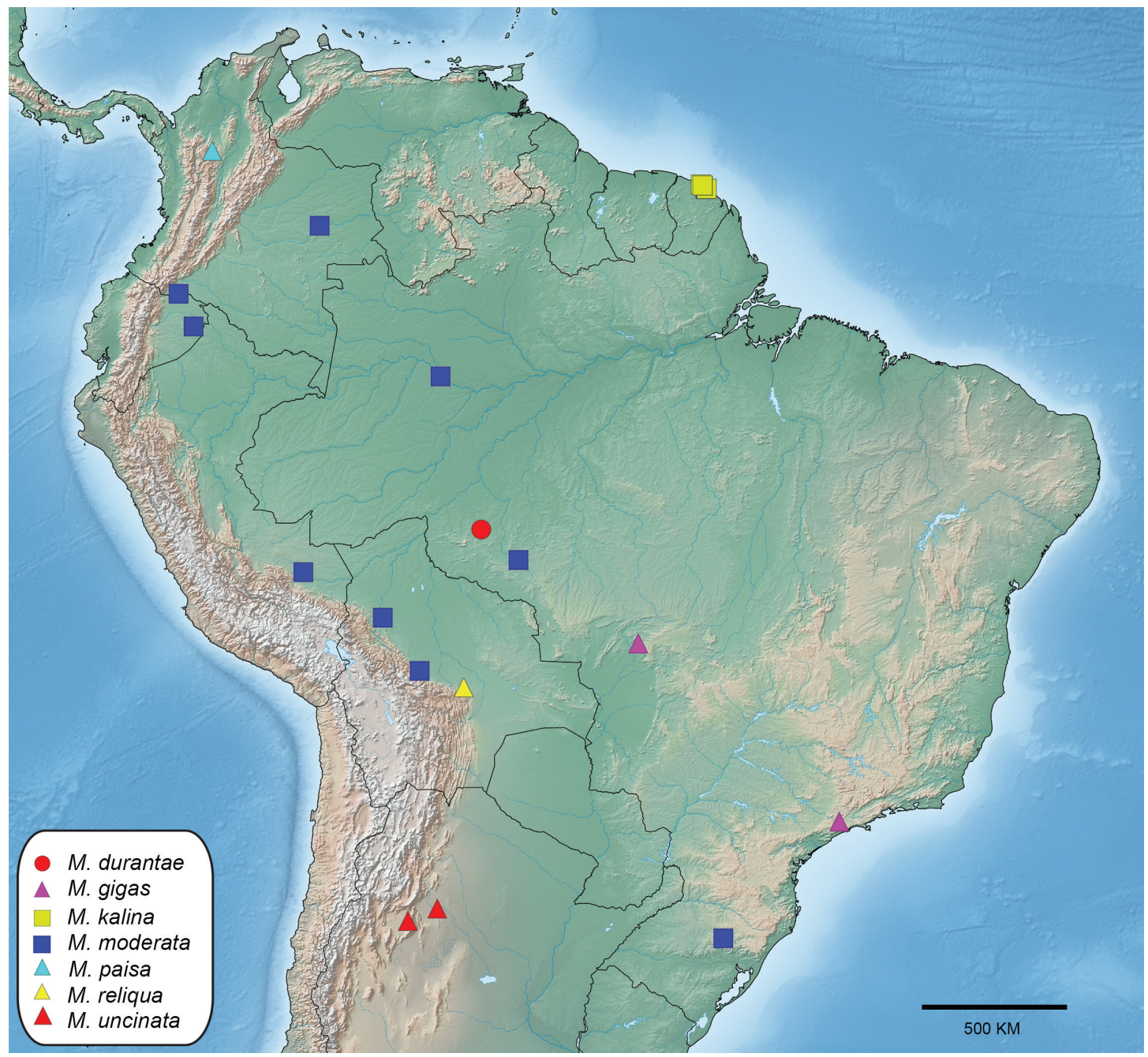

FIGURE 21. Collection localities for species of Megachile (Zonomegachile).

relationship to the other species of the group and it might belong to a different subgenus or be a basal member phenotypically removed from the remaining taxa of the group.

\section{Megachile (Zonomegachile) durantae,} new species

Figures 21, 22

Diagnosis: This species can be recognized by the following combination of features: head and mesosoma mainly with whitish pubescence (fig.
22A-D); mesoscutum microalveolate to imbricate among setiferous punctures; probasitarsus robust, about $2.5 \times$ longer than broad (fig. $22 \mathrm{~F}$ ); S2 with white scopal setae, S3 and S4 yellowish, sides of S3, S4, and entire S5 and S6 black. This species is most similar to M. paisa, n. sp., from northwestern Colombia. In addition to the geographic separation, it can be distinguished by the pubescence of the head and mesosoma, which is light reddish brown in $M$. paisa and whitish in M. durantae, n. sp. The wings in $M$. durantae are also slightly less yellow than in $M$. paisa. 

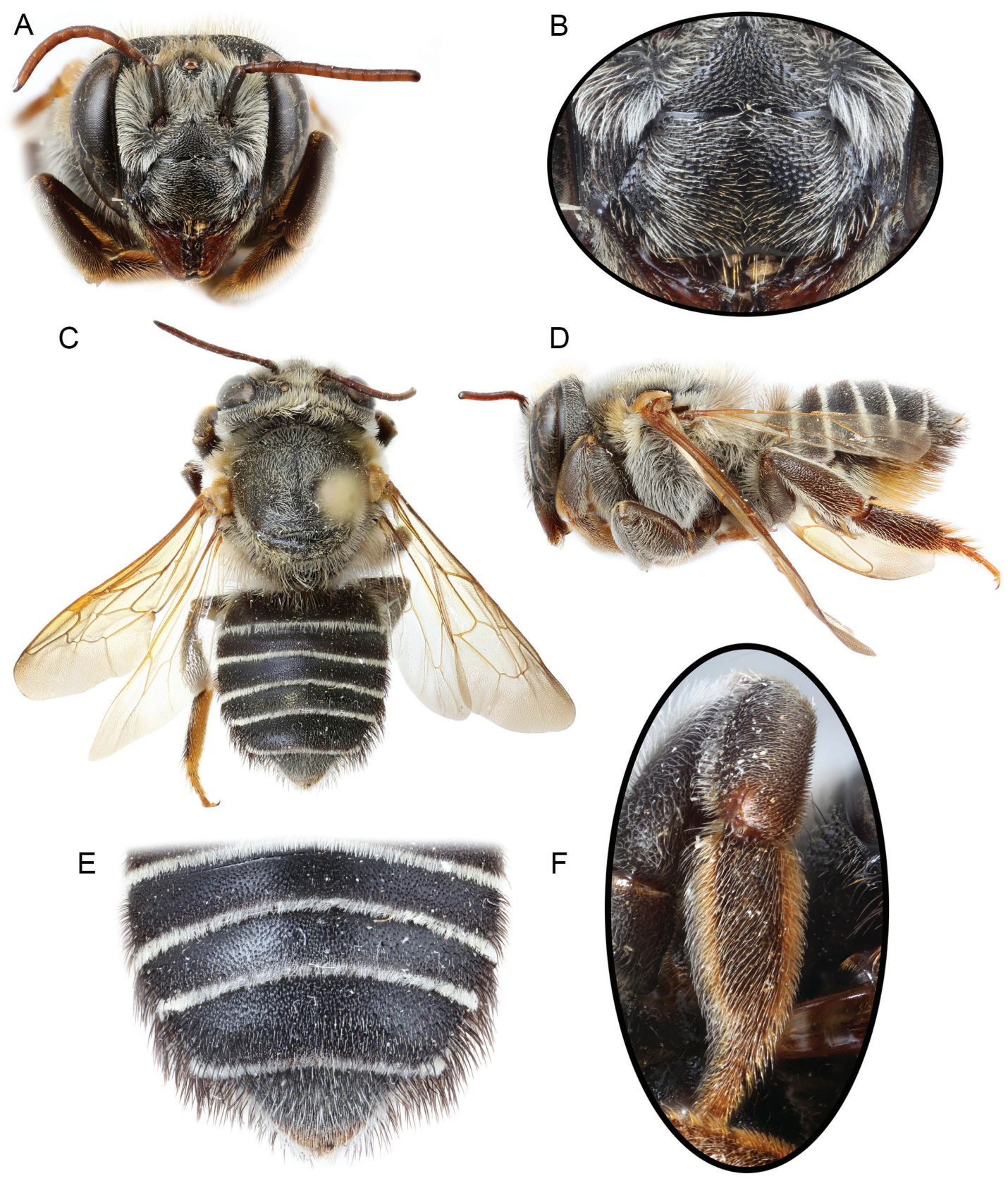

FIGURE 22. Female holotype of Megachile (Zonomegachile) durantae Gonzalez, Griswold, and Engel, new species. A. Facial view. B. Detail of clypeus and supraclypeal area. C. Dorsal habitus. D. Lateral habitus. E. Dorsal view of T3-T5. F. Outer surface of protibia and protarsus. 
Description: Holotype, Female: total body length $12.6 \mathrm{~mm}$; forewing length $10.5 \mathrm{~mm}$; head width $4.6 \mathrm{~mm}$. Head $1.3 \times$ wider than long; inner orbits of compound eyes parallel or nearly so; intertorular distance $1.5 \times$ torulorbital distance; interocellar distance $2.6 \times \mathrm{OD}$, slightly longer $(1.1 \times)$ than ocellocular distance; ocelloccipital distance $2.0 \times \mathrm{OD}, 0.8 \times$ ocellocular distance; clypeus with distal margin straight or nearly so; scape $3.6 \times$ longer than broad, pedicel slightly shorter than F1, about as long as broad, F1 about as long as F2, each flagellomere longer than broad, distalmost flagellomere longest, $2.3 \times$ longer than broad. Proand mesobasitarsi each $2.5 \times$ longer than broad; metatibia $2.9 \times$ longer than broad; metabasitarsus $3.0 \times$ longer than broad, shorter $(0.9 \times)$ and narrower $(0.8 \times)$ than metatibia.

Body color black, except: outer surface of mandible light reddish brown (excluding distal margin); legs and basal sterna dark reddish brown. Wings slightly yellowish, slightly darker apically; tegula, veins, and pterostigma yellowish.

Pubescence predominantly white except: sides of clypeus and inferior paraocular area with scattered dark brown setae; outer surfaces of proand mesobasitarsi and inner surfaces of tarsi with light reddish-brown setae; S3 and S4 with yellowish setae; sides of propodeum and disc of T1 with scattered grayish setae; sides of T3-T6, sides of S3, S4, and entire S5 and S6 with black setae. Apical margins of S2-S4 laterally, and entire margins of T1-T5 and S5 with distinct white fasciae. Outer surfaces of pro- and mesotibiae uniformly covered with rather dense (integument visible among setae), simple, apically curved setae. Pro- and mesobasitarsi with short, dense, bottlebrushlike pubescence.

Face and vertex densely punctate $(0.5-1.5 \times$ $\mathrm{PW})$, punctures sparser on discs of clypeus and supraclypeal area, integument weakly imbricate to smooth and shiny among punctures; gena with shallower, larger punctures than on vertex; outer surface of mandible apically, above nearly smooth and shiny outer ridge, minutely punctate, somewhat dull. Mesoscutum microalveolate to imbricate among setiferous punctures larger and sparser than on vertex; mesoscutellum imbricate, axilla dorsally nearly smooth and shiny, both with widely separated punctures $(\geq 2.0 \times \mathrm{PW})$; mesepisternum smooth and shiny with sparser punctures about as large as those on mesoscutum; metepisternum and propodeum imbricate. Terga weakly imbricate with smaller, sparser punctures than mesoscutum, punctures coarser and denser on T5; sterna strongly imbricate, coarsely punctate, punctures smaller and closer on basal sterna.

Holotype: + , Brazil: Rondonia, Fazenda Rancho Grande, $62 \mathrm{~km} \mathrm{~S}$. Ariquemes, $165 \mathrm{~m}$, S10,32, W62,48, 12-22 November 1991, E.M. Fisher collector (BBSL).

Eтymology: The specific epithet honors the late Silvana Patricia Durante (1965-2016), Argentinean melittologist who made many important contributions to our understanding of the South American megachilid fauna.

\section{Megachile (Zonomegachile) gigas Schrottky}

Figures 5G, H, 21, 23

Megachile gigas Schrottky, 1908: 235 (neotype ô [here designated], examined, ANSP 4133). Silveira et al., 2002: 215 (placement in Zonomegachile Mitchell).

Megachile sanctipauli Schrottky, 1913: 205 (neotype $\delta$ [here designated], examined, ANSP 4133). Silveira et al., 2002: 214 (placement in Pseudocentron Mitchell).

Megachile aequalis Mitchell, 1930: 246 (holotype ô, examined, ANSP 4133: Mato Grosso, Chapada dos Guimarães). Mitchell, 1943: 666 (placement in Chrysosarus Mitchell). Moure, 1948: 332 (placement in Acentron Mitchell).

Diagnosis: Both sexes of this species are easily recognized by $\mathrm{T} 1-\mathrm{T} 4$ with dense, appressed, apical yellow fasciae, legs orange, and wings yellow. The hypostomal tooth is strong in the male (fig. 5G), distinctive in frontal view as in $M$. kalina, n. sp. However, the latter species lacks the 

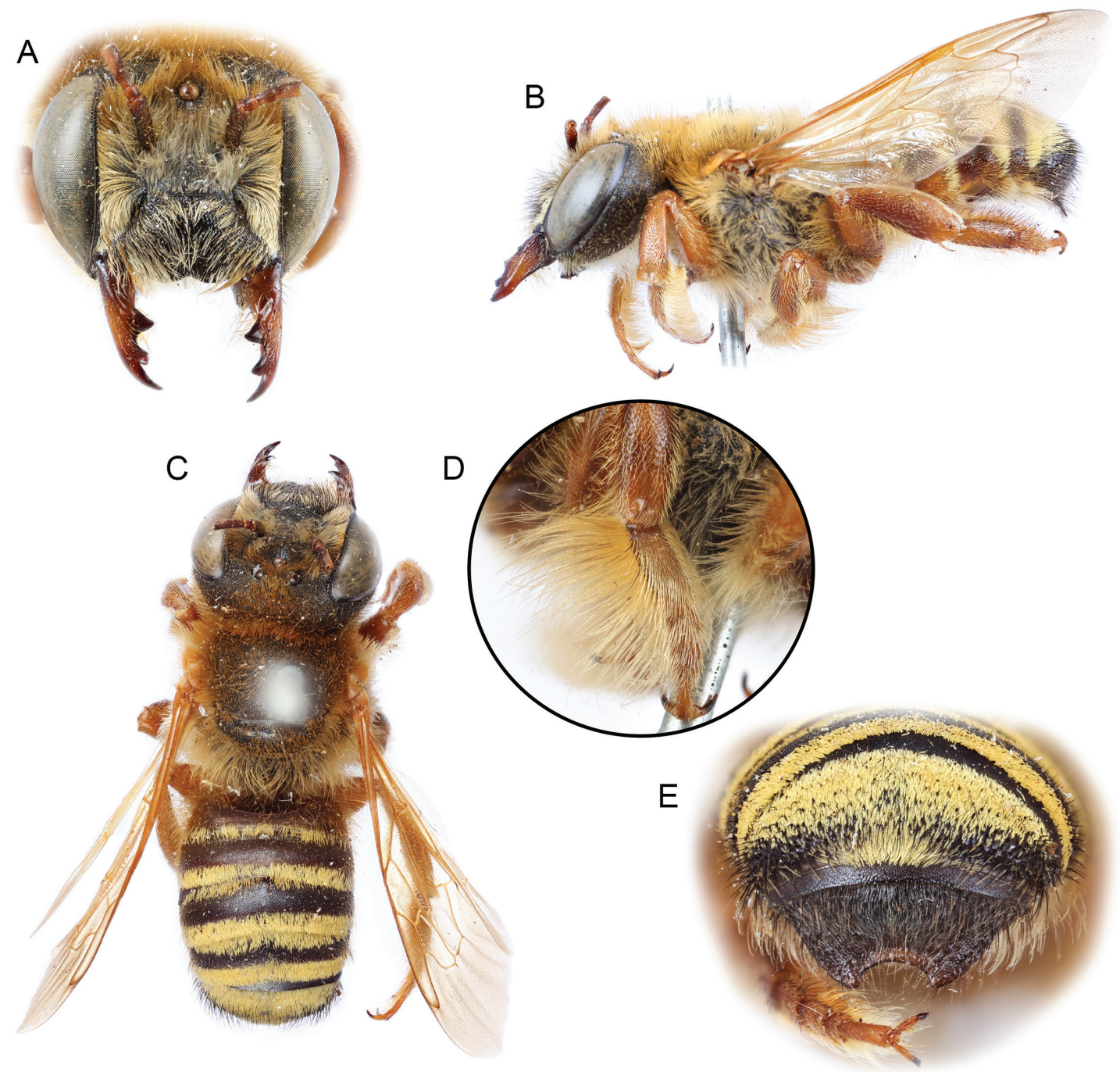

FIGURE 23. Male holotype of Megachile aequalis Mitchell, a junior subjective synonym of M. (Zonomegachile) gigas Schrottky. A. Facial view. B. Lateral habitus. C. Dorsal habitus. D. Outer surface of mesotarsus. E. Dorsal view of $\mathrm{T} 5$ and $\mathrm{T} 6$.

distinctive coloration of the wings and legs and the yellow fasciae on the terga.

Description: Male: total body length 14.6 $\mathrm{mm}$; forewing length $10.0 \mathrm{~mm}$; head width 5.1 $\mathrm{mm}$. Head $1.3 \times$ wider than long; inner orbits of compound eyes straight or nearly so; intertorular distance $1.5 \mathrm{x}$ times torulorbital distance; interocellar distance $2.2 \times \mathrm{OD}, 0.9 \times$ ocellocular distance; ocelloccipital distance $3.6 \times \mathrm{OD}, 1.5 \times$ ocellocular distance; scape $3.1 \times$ longer than broad, pedicel shorter than F1, about as long as broad, F1 1.3× longer than broad, shorter than F2, remaining flagellomeres longer than broad. Clypeus emarginate medially on distal margin; hypostomal area with strong, anteriorly projected tooth, distinct in frontal view. Procoxa with apical spine long, about $1.5 \times$ OD; protibia with posterior margin rounded, not carinate; probasitarsus parallel-sided, $2.3 \times$ longer than broad; mesobasitarsus $1.9 \times$ longer than broad; 
metabasitarsus $3.0 \times$ longer than broad. Preapical carina of T6 with semicircular emargination, $2.9 \times$ broader than deep, tooth lateral to emargination blunt, orthogonal.

Head and mesosoma black, except: mandible dark reddish brown; scape and pedicel dark brown, flagellum light reddish brown; legs light reddish brown to orange with proand mesotarsi yellowish. Terga dark brown; sterna brownish. Wings, tegula, pterostigma, and veins yellowish.

Pubescence light reddish brown except: clypeus (erect setae), discs of T1-T3, and posterior margin of metabasitarsus with dark brown setae; inferior margin of hypostomal tooth apically and apex of procoxal spine with tuft of short, dense, stiff light reddish-brown setae; clypeus (appressed setae), supraclypeal area, gena, hypostomal area, and sterna with whitish setae; sides of T3 and T4 with dark brown setae; discs of T5 and T6 with erect, long (1.5-2.0× OD) dark brown to black setae. Protarsi with dense fringe of long setae along their posterior margin, $1.3 \times$ longer than width of basitarsus; mesotarsi with sparser, longer fringe of setae than on protarsi, at least $3.5 \times$ longer than width of basitarsus (fig. 23D). Distal margins of T1-T4, discs of T3 and T4 basally, and nearly entire disc of $\mathrm{T} 5$ with dense, appressed, yellow fascia obscuring integument. S1-S4 with apical fasciae longer than on terga.

Face and vertex with coarse, nearly contiguous punctures; clypeus with punctures shallower and larger than on vertex; supraclypeal area with minute, fine punctures; gena with shallower, larger punctures than on vertex, punctures becoming smaller, coarser inferiorly. Mesoscutum coarsely and densely $(\leq 0.5 \times \mathrm{PW})$ punctate, punctures slightly larger than on vertex, integument among punctures imbricate; mesoscutellum and axilla shinier, with sparser punctures than on mesoscutum; mesepisternum with punctures larger, sparser than on mesoscutum, becoming smaller, denser dorsally; metepisternum and lateral and posterior surfaces of propodeum strongly imbricate, punctures on metepisternum and lateral surface of propodeum slightly smaller and sparser than those on mesepisternum dorsally, becoming smaller, shallower, and widely separated $(\geq 1.0 \times$ $\mathrm{PW}$ ) on posterior surface of propodeum; propodeal triangle microalveolate; metanotum weakly imbricate with smaller, shallower punctures than on mesoscutellum, separated by at most a puncture width; legs weakly imbricate to smooth and shiny with coarse punctures on outer surfaces of tibiae. Terga weakly imbricatelineolate, weakly shiny, minutely and uniformly punctate, punctures separated by at least two puncture widths on basal terga, denser on T4 and T5; T6 with coarse, nearly contiguous punctures, much larger than on preceding terga; sterna strongly imbricate, with coarser, sparser punctures than on terga.

Holotype (M. aequalis): §, Chapada/Nov./ Megachile aequalis Mitchell, Type 4133 (ANSP).

Neоtype (M. gigas, here designated): $\widehat{0}$, Chapada/Nov./Megachile aequalis Mitchell, Type 4133 (ANSP). Schrottky (1908) described this species from a female specimen from São Paulo, Brazil, and the type now lost (Rasmussen et al., 2009). It has been widely recognized that M. gigas, M. sanctipauli Schrottky (whose type is also lost, see below), and M. aequalis Mitchell are synonyms (e.g., Moure et al., 2007). Accordingly, we here designate as neotype the holotype of $M$. aequalis (the only surviving type specimen for the three species-group names involved) thereby rendering these names as objective synonyms and stabilizing their nomenclatural application.

Neотуре (M. sanctipauli, here designated): ๙o, Chapada/Nov./Megachile aequalis Mitchell, Type 4133 (ANSP). Schrottky (1913) described this species from a male specimen from São Paulo, Brazil, and the type now lost (Rasmussen et al., 2009). As noted above, it has been widely recognized that $M$. sanctipauli, M. gigas, and $M$. aequalis are synonyms (e.g., Moure et al., 2007). Accordingly, we here designate as neotype the holotype of $M$. aequalis thereby rendering these 


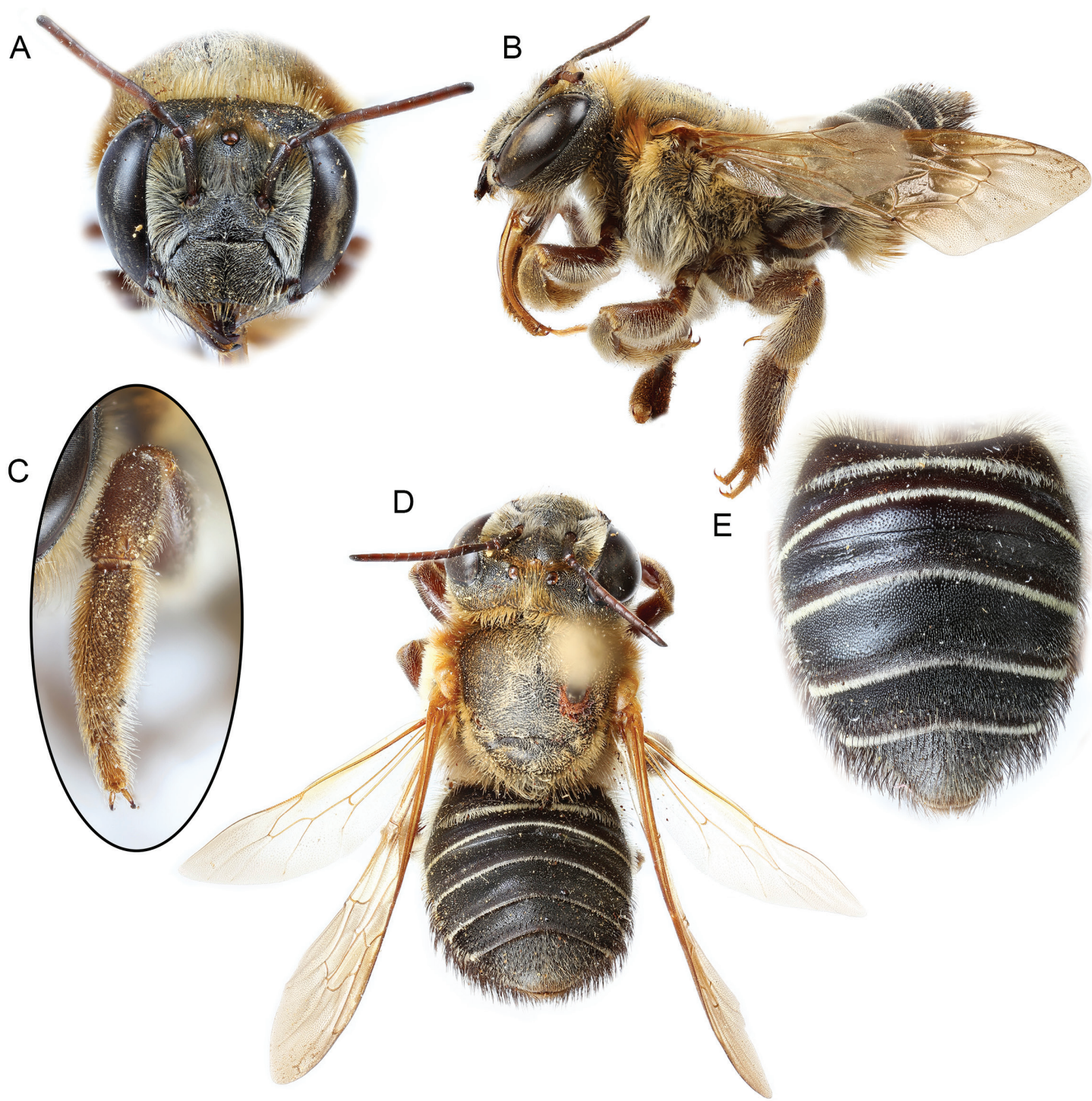

FIGURE 24. Female paratype of Megachile (Zonomegachile) kalina Gonzalez, Griswold, and Engel, new species. A. Facial view. B. Lateral habitus. C. Outer surface of protibia and protarsus. D. Dorsal habitus. E. Dorsal view of metasoma (A, B, D: SEMC 1204560; C, E: SEMC 1204557).

names as objective synonyms and stabilizing their nomenclatural application.

Paratypes $(n=2 \hat{\jmath} \hat{\jmath}): 2 \hat{\jmath} \hat{\jmath}$, same data as holotype (ANSP).

Comments: The whereabouts of the female type of $M$. gigas Schrottky as well as the male type of M. sanctipauli Schrottky are unknown. They are probably lost as for many other species described by Curt Schrottky (Rasmussen et al., 2009). The description presented here is therefore based on the male holotype and two male paratypes of $M$. aequalis Mitchell deposited in ANSP. We were not able to examine females of this species and thus, female characters mentioned in the diagnosis and keys were taken from the original description (Schrottky, 1908). 


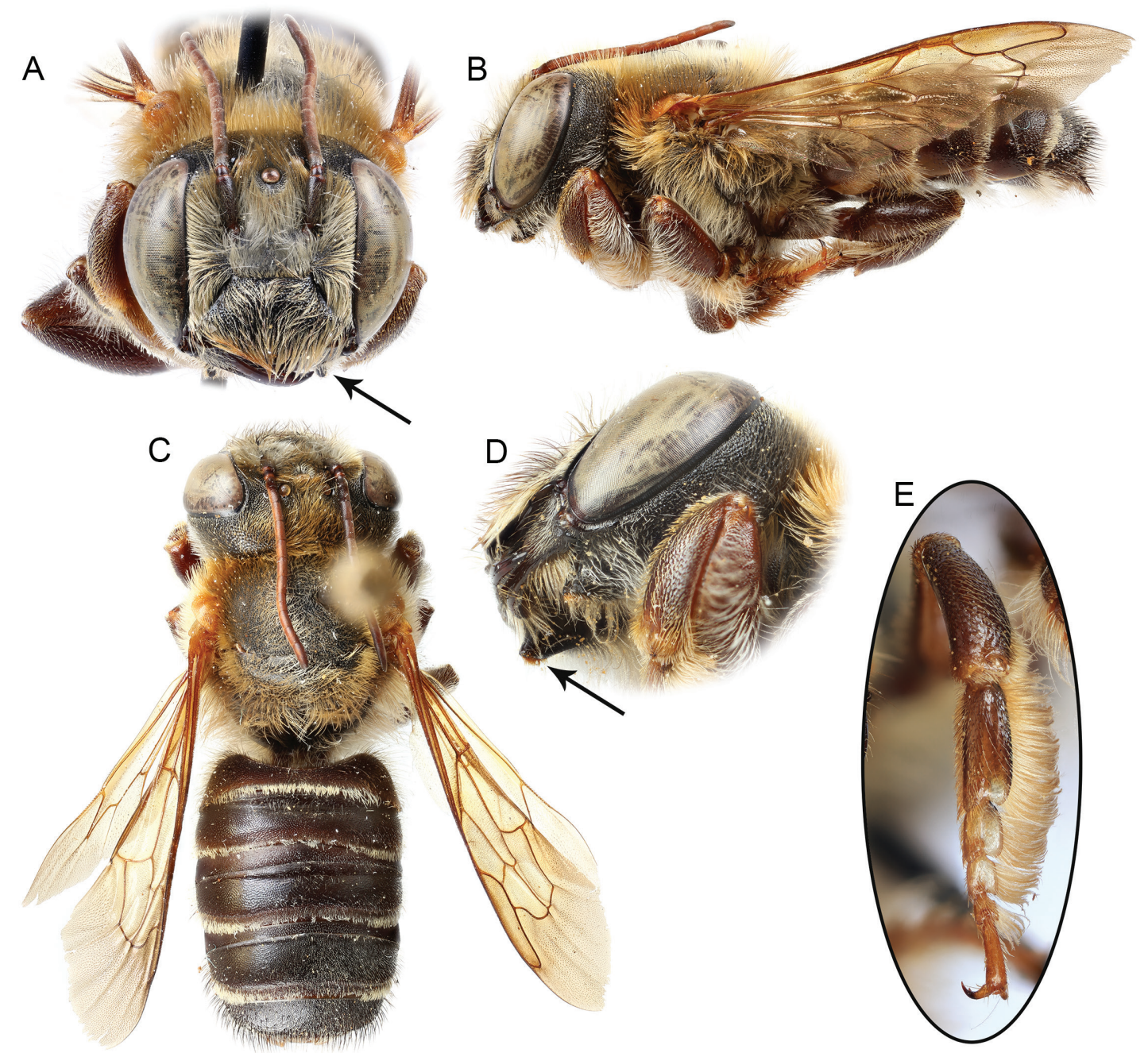

FIGURE 25. Male holotype of Megachile (Zonomegachile) kalina Gonzalez, Griswold, and Engel, new species, except figures D and E (paratype, SEMC 1178928). A. Facial view. B. Lateral habitus. C. Dorsal habitus. D. Lateroinferior view of head. E. Outer surface of mesotarsus. Arrow points to hypostomal projection.

\section{Megachile (Zonomegachile) kalina, new species}

Figures 2, 6F, 21, 24-27

Diagnosis: The male of this species is easily recognized by the following combination of features: hypostomal tooth strong, clearly visible in frontal view (fig. 25A, D); protarsus clearly expanded, with dense fringe of setae along the posterior margin (fig. 25E); mesoscutum imbri- cate with dense, coarse punctures; and T5 finely and uniformly punctate. The female can be separated by the punctation of the mesoscutum and T5, which is similar to that of the male, and the pro- and mesobasitarsi which are elongate and with rather long, sparse setae (fig. 24C).

DESCRIPTION: Holotype (paratypes in parentheses), Male: total body length 14.2 (12.9-14.2) $\mathrm{mm}$; forewing length $9.5(9.2-9.7) \mathrm{mm}$; head width $5.1(4.8-5.2) \mathrm{mm}$. Head $1.3 \times$ wider than 
long; inner orbits of compound eyes straight or nearly so; intertorular distance $1.6 \times$ times torulorbital distance; interocellar distance $2.2 \times \mathrm{OD}$, $0.9 \times$ ocellocular distance; ocelloccipital distance $3.6 \times \mathrm{OD}, 1.5 \times$ ocellocular distance; scape $2.9 \times$ longer than broad, pedicel shorter than F1, about as long as broad, F1 $1.3 \times$ longer than broad, shorter than F2, remaining flagellomeres longer than broad. Clypeus weakly emarginate medially on distal margin; hypostomal area with strong, anteriorly projected tooth, distinct in frontal view. Procoxa with apical spine long, about $1.5 \times$ OD; protibia with posterior margin rounded, not carinate; probasitarsus parallel sided, $2.3 \times$ longer than broad; mesobasitarsus $2.2 \times$ longer than broad; metabasitarsus $2.5 \times$ longer than broad. Preapical carina of T6 with semicircular emargination, $2.1 \times$ broader than deep, tooth lateral to emargination blunt, orthogonal. Genital capsule and associated terga and sterna as in figure 26.

Head and mesosoma black, except: mandible dark reddish brown; scape and pedicel dark brown, flagellum light reddish brown; legs light reddish brown with pro- and mesotarsi yellowish. Tegula yellowish; wings yellowish, darker apically; pterostigma yellowish, veins brownish. Terga dark brown to black except preapical carina of T6 light reddish brown; sterna brownish with preapical margins of S2-S4 yellowish.

Pubescence white except: clypeus, discs of T1-T3, and posterior margin of metabasitarsus with dark grayish-brown setae; inferior margin of hypostomal tooth and apex of procoxal spine with tuft of short, dense, stiff light reddish-brown setae; paraocular area, vertex, pronotal lobe, and dorsum of mesosoma laterally with yellowish to light reddish-brown setae; sides of T3 and T4, and discs of T5 and T6 with erect, long (1.5-2.0x OD) dark brown to black setae. Protarsus with dense fringe of long setae along its posterior margin, $1.4 \times$ longer than width of probasitarsus; mesotarsus with sparser, longer fringe of setae than on protarsus, at least $4.0 \times$ longer than width of mesobasitarsus. T1-T5 and S1-S4 with dense apical fasciae, longer on sterna.
Face and vertex with coarse, nearly contiguous punctures; clypeus with punctures shallower and larger than on vertex; supraclypeal area with minute, fine punctures; gena with shallower, larger punctures than on vertex, punctures becoming smaller, coarser inferiorly. Mesoscutum coarsely and densely $(\leq 0.5 \times \mathrm{PW})$ punctate, punctures slightly larger than on vertex, integument among punctures imbricate; mesoscutellum and axilla with sparser punctures than on mesoscutum; mesepisternum with punctures larger, sparser than on mesoscutum, becoming smaller, denser dorsally; metepisternum and lateral and posterior surfaces of propodeum strongly imbricate, punctures on metepisternum and lateral surface of propodeum slightly smaller and sparser than those on mesepisternum dorsally, becoming smaller, shallower, and widely separated $(\geq 1.0 \times \mathrm{PW})$ on posterior surface of propodeum; propodeal triangle micro-alveolate; metanotum weakly imbricate with smaller, shallower punctures than on mesoscutellum, separated by at most a puncture width; legs weakly imbricate to smooth and shiny with coarse punctures on outer surfaces of tibiae. Terga weakly imbricate-lineolate, weakly shiny, minutely and uniformly punctate, punctures separated by at least two puncture widths on basal terga, denser on T4 and T5; T6 with coarse, nearly contiguous punctures, much larger than on preceding terga; sterna strongly imbricate, with coarser, sparser punctures than on terga.

Female: As described for the male, except as follows: total body length $10.8-15.8 \mathrm{~mm}$; forewing length 9.1-10.8 $\mathrm{mm}$; head width 4.4-5.1 $\mathrm{mm}$. Intertorular distance $1.4 \times$ torulorbital distance; interocellar distance $2.8 \times \mathrm{OD}$, about as long as ocellocular distance; ocelloccipital distance $2.7 \times$ OD, about as long as ocellocular distance; clypeus with distal margin straight or nearly so; scape $3.7 \times$ longer than broad, F1 about as long as F2. Probasitarsus $\sim 3 \times$ longer than broad; mesobasitarsus $2.8 \times$ longer than broad; metatibia $3.0 \times$ longer than broad; metabasitarsus $3.1 \times$ longer than broad, shorter $(0.9 \times)$ and narrower $(0.9 \times)$ than metatibia. 

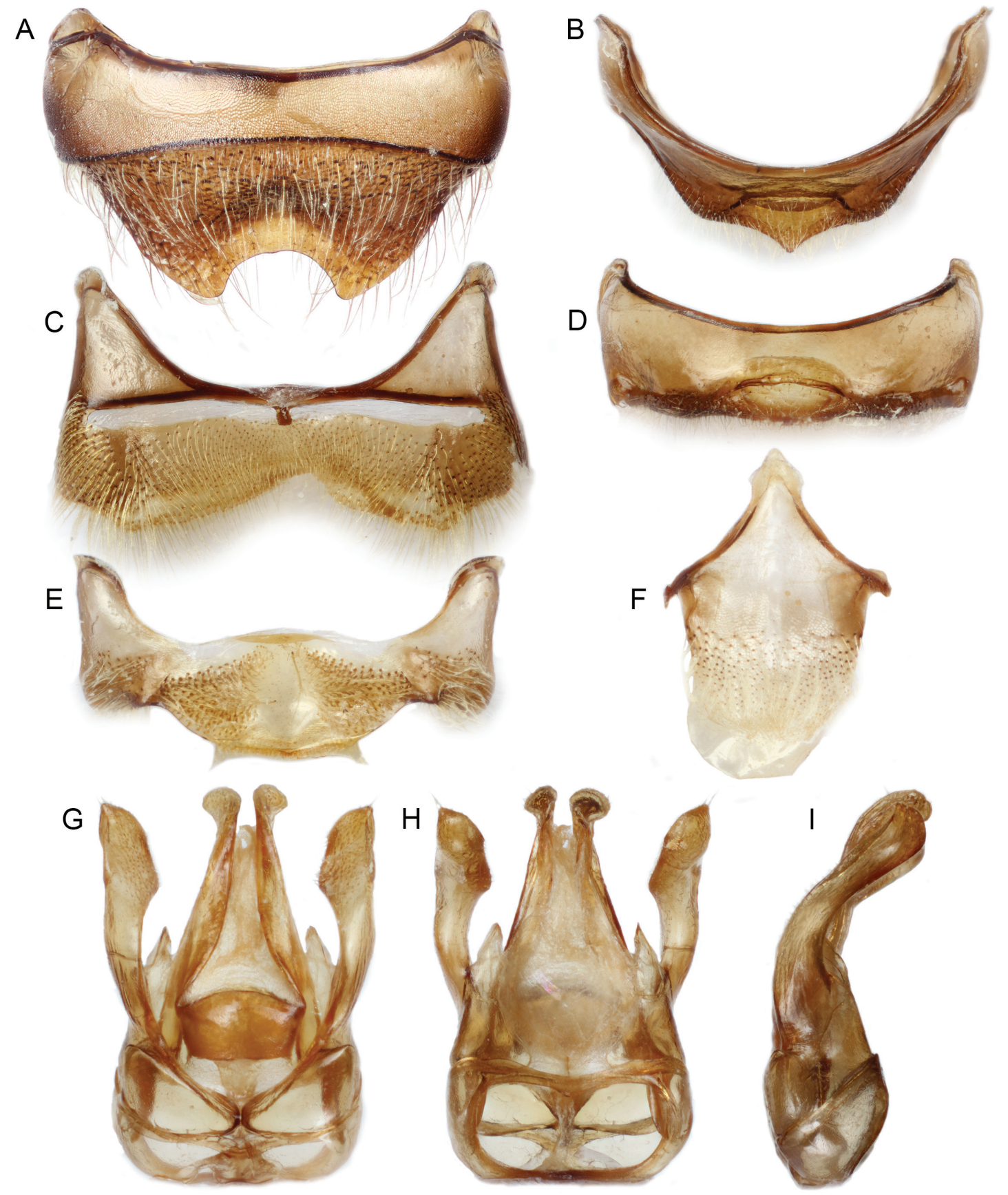

FIGURE 26. Male paratype of Megachile (Zonomegachile) kalina Gonzalez, Griswold, and Engel, new species (paratype, SEMC 1178928). A. Sixth tergum, dorsal view. B, D. Seventh tergum in dorsal and ventral views. C. Fifth sternum. E. Sixth sternum. F. Eighth sternum. G-I. Genital capsule in dorsal, ventral, and lateral views. 
Outer surface of mandible apically orange, except for dark brown to black distal margin. Metasoma black with basal sterna brownish.

Sides of clypeus and inferior paraocular area with scattered dark brown setae; outer surfaces of pro- and mesobasitarsi and inner surfaces of tarsi with light reddish-brown setae; S2 and bases of S3 and S4 with whitish setae, remaining areas of S3 and S4, and entire S5 and S6 with dark grayish-brown setae; apical margins of S3 and S4 laterally, and entire margins of T1-T5 and S5 with distinct white fasciae. Outer surfaces of proand mesotibiae, and pro- and mesobasitarsi with sparser, longer setae than in $M$. durantae, not forming distinct brushes.

Punctures in general finer and sparser than in male. Clypeus and supraclypeal area with sparser punctures on discs; outer surface of mandible apically, above nearly smooth and shiny outer ridge, minutely punctate, somewhat dull. Mesoscutum with punctures separated by $0.5-1.0 \times$ PW; mesoscutellum and axilla dorsally with widely separated punctures $(\geq 2.0 \times \mathrm{PW})$.

Holotype: $\hat{0}$, French Guiana: Kourou (beach), 2 March 1977, C.D. Michener (SEMC 178936).

PARATYPES $(n=22 \hat{\jmath}, 11 ㅇ ㅜ): 4 ㅇ ㅜ, 9 \hat{0}$ with same data as holotype and the following barcode numbers: SEMC 1204526, 1204532-34, 1178927-29, 1178931-35, 1178937 (SEMC); remaining paratypes from the same locality but collected by David Roubik as follows: 10 , III-277 [2 March 1977]/SEMC 1178970 (SEMC); $2 ㅇ ㅜ, 10,4$ April 1977, $\mathrm{N}^{\circ}$. 31, 36/SEMC 1178971, 1204564, -66 (SEMC); 19,7 April 1977, No. 24/SEMC 1204568 (SEMC); 10,7 May 1977, No. 40/SEMC 1204572 (SEMC); 1 , Kourou, Km 25 NW, 14 Feb 77 [1977], em. [emerged], No./SEMC 1204562 (SEMC); 1 t, ut supra, 12 Nov 76, Nº. 69/SEMC 1178966 (SEMC); 2 ठิ đે, ut supra, 12 Dec 76 [1976], em./ SEMC 1178967, 1204557 (SEMC); 2 우, 10 , ut supra, 23 Dec 76 [1976], em \#1, \#2, \#3/SEMC 1178969, 1204559, -60 (SEMC); 1 ㅇ, ut supra, 28 Nov, emerged/SEMC 1204554 [brood cell attached] (SEMC); 3 ôे, ut supra, egg $11 \mathrm{Nov} /$ em. 11 Dec 76/SEMC 1178965, 1204556, 1204553 [brood cell attached] (SEMC); 19,10 , ut supra, Km 27 NW, XII-13-76 [13 July 1976]/SEMC 1178968, 1204558 (SEMC); $1 \hat{\delta}$, ut supra, Km 37 NW, 8 Nov- em 12 Dec 76/SEMC 1178964 [brood cell attached] (SEMC).

Eтymology: This species is named after the Kalina people who inhabited the northern coastal areas of South America.

Nesting: Three paratypes have, attached to the same pin, the brood cells from which they emerged. Brood cells consisted exclusively of leaf pieces. One female and one male specimen each has a single cell (fig. 27), while at least three cells are associated to the third male specimen. The following comments on the cell morphology are from the dissection of a single cell attached to the pin of one of the male paratypes. Cells ranged from 13 to $16 \mathrm{~mm}$ in length and from 7 to $8 \mathrm{~mm}$ in diameter. The cell cup consisted of three layers of leafs, each made of three oval disks. Each oval disk ranged $15-20 \mathrm{~mm}$ in length $(\overline{\mathrm{X}}=17.2$, S.D. $\pm 1.85, n=6)$ and $10.1-12.0 \mathrm{~mm}$ in width $(\bar{X}=11.0$, S.D. \pm 0.67 , $n=6)$. Oval disks were braced internally by two circular disks (7.2 and $7.8 \mathrm{~mm}$ in diameter) placed at the bottom of the cup, as illustrated by Kim (1992) for M. (Litomegachile) gentilis Cresson. These circular disks supported the first and second layer of leaf pieces of the cell cup. Two circular disks, as inferred by the two rings that remained around the emergence hole, closed the cell.

\section{Megachile (Zonomegachile) moderata Smith}

Figures 4F, 6A-C, 21, 28-30

Megachile moderata Smith, 1879: 74 (holotype +, examined, BMNH 17A.2430: "Ega [Tefé], Amazonas, Brazil). Silveira et al., 2002: 215 (placement in Zonomegachile Mitchell). Megachile mariannae Dalla Torre, 1896: 438, nomen vanum (unnecessary replacement name for M. moderata Smith).

Chrysosarus (Zonomegachile) mariannae (Dalla Torre); Mitchell, 1980: 72. 


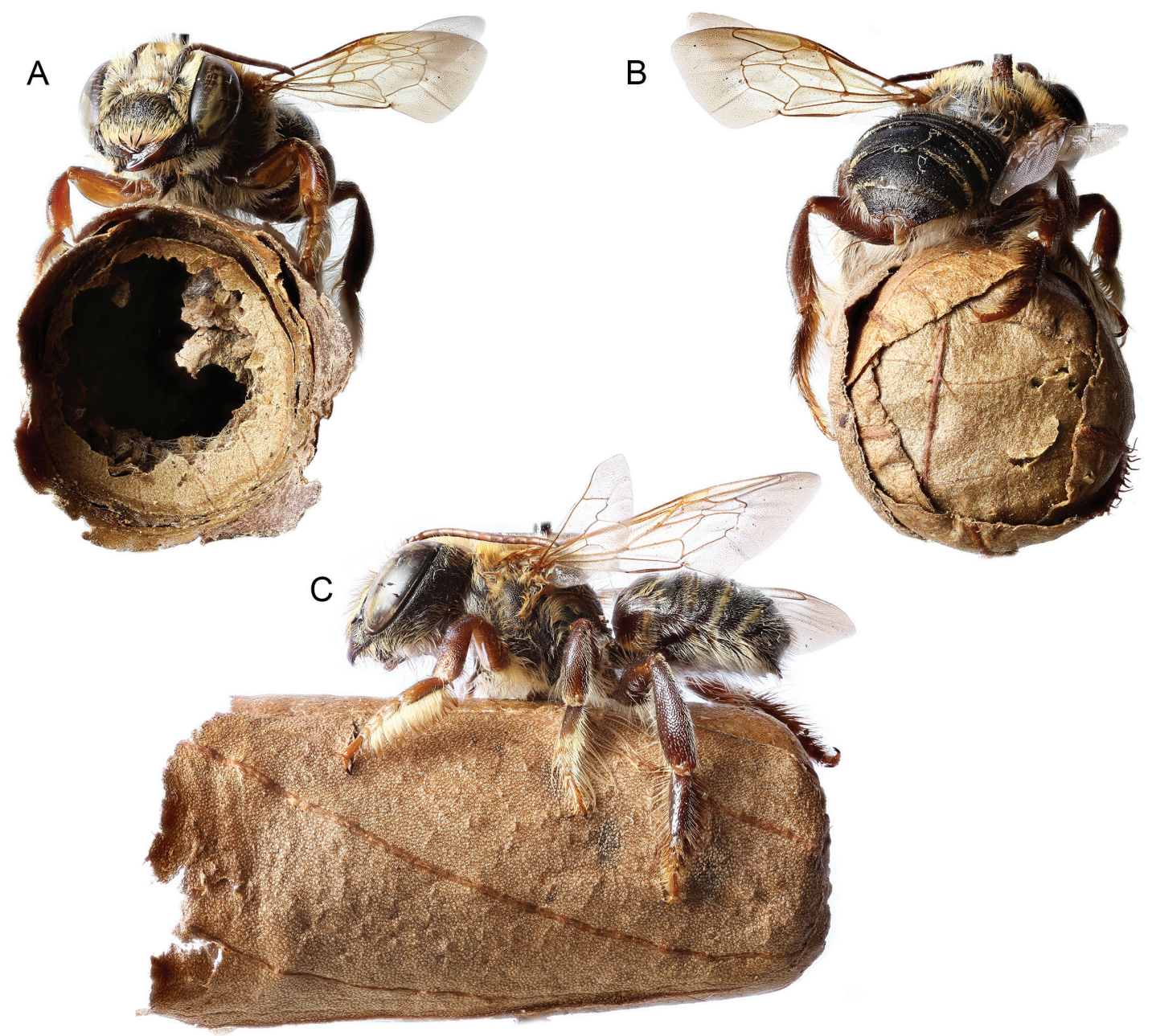

FIGURE 27. Brood cell attached to a male specimen of Megachile (Zonomegachile) kalina Gonzalez, Griswold, and Engel, new species (paratype, SEMC 1178964). A. Frontal view showing emergence hole. B. Posterior view. C. Lateral habitus.

Diagnosis: The female of this species is most similar to $M$. durantae and M. paisa. It shares with both species a mesoscutellum that is imbricate among setiferous punctures (fig. 28C), and it can be recognized by the S5 with mostly yellowish setae (with black setae in $M$. durantae and $M$. paisa) and the mesoscutellum and terga with finer and denser punctures. The males, tentatively associated with this species (see Comments, below), can be recognized by the combination of a small, anteriorly directed hypostomal tooth, not distinct in frontal view (fig. 29A, D); inferior margin of mandible basally with dark gray or black branched setae; procoxa with apical spine short, about as long as an OD; and probasitarsus not or barely expanded posteriorly, about $2.7 \times$ longer than broad, with a sparser fringe on the posterior margin (fig. 29E).

Redescription: Holotype, Female: As described for $M$. durantae except as follows: total body length $14.8 \mathrm{~mm}$; forewing length $10.5 \mathrm{~mm}$; 

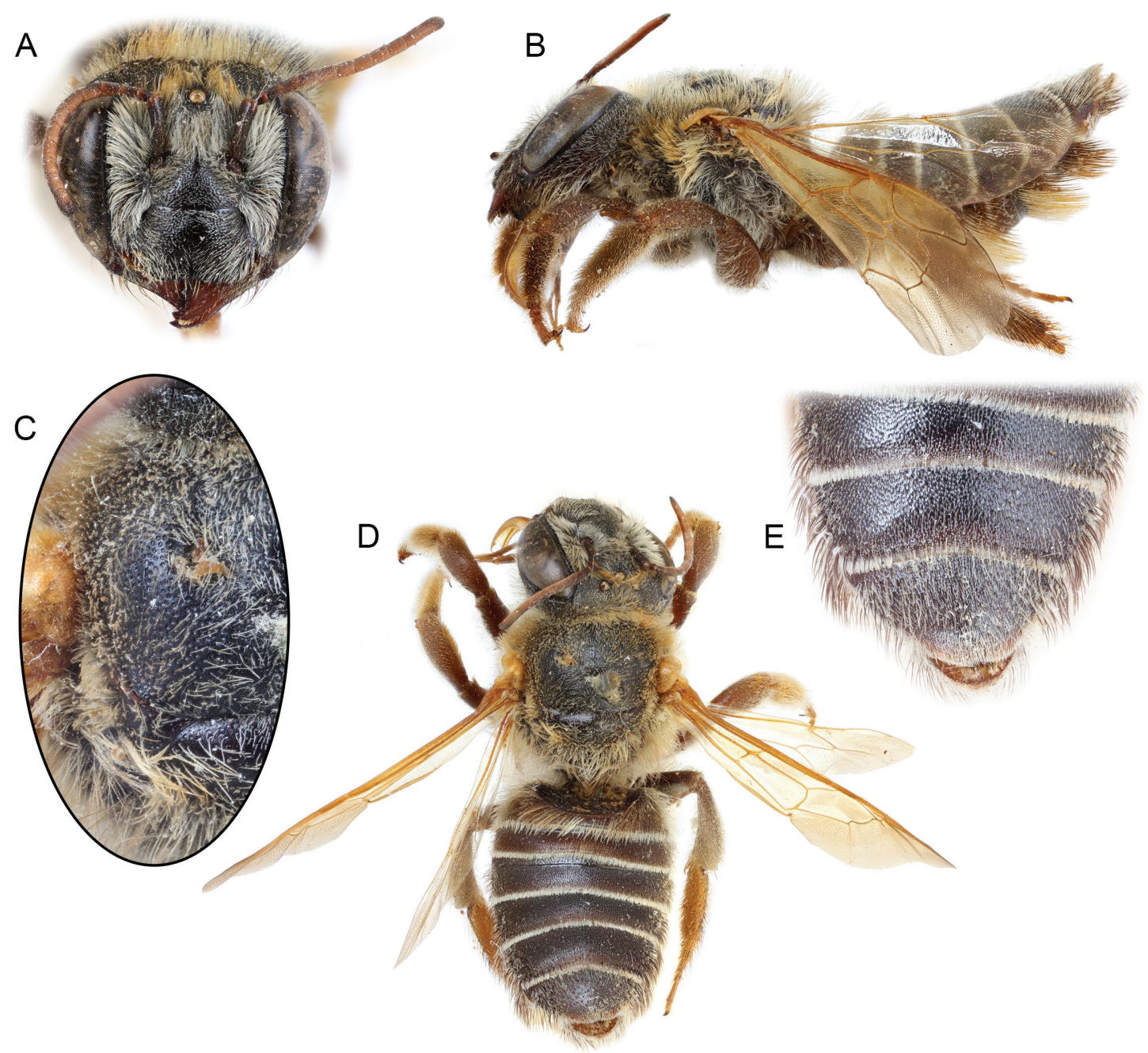

FIGURE 28. Female holotype of Megachile (Zonomegachile) moderata Smith. A. facial view. B. Lateral habitus. C. Detail of mesoscutum and mesoscutellum in dorsal view. D. Dorsal habitus. E. Detail of T4-T6.

head width $4.4 \mathrm{~mm}$. Intertorular distance $1.4 \times$ torulorbital distance; interocellar distance $2.8 \times$ OD.

Body color dark reddish brown except: outer surface of mandible light reddish brown (excluding distal margin); tegula yellowish; mesosoma excluding legs black; and discs of T2-T6 dark brown. S3-S5 with mostly yellowish setae, dark grayish-brown setae on sides only; S6 with dark grayish-brown setae. Wings slightly more yellow than those of $M$. durantae.

Mesoscutum and terga with punctures slightly finer and denser than in M. durantae.
Holotype: + , Ega [Tefé]/Ega/Type/B.M. Type Hym. 17a.2430/Megachile moderata (Type) Sm (BMNH).

Additional material examined $(n=$

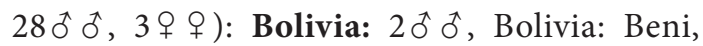
Reyes, 10 December 1956 (L. Peña)/SEMC 1179006-07 (SEMC); 3 के ô, Bolivia: Dpto. La Paz, Alta Marani, N of Rurrenbaque, 10 Nov 1956 (L. Peña)/SEMC 1179004, -005, 1204249 (SEMC); $1 \hat{0}$, Bolivia, La Paz, Altamarani, N. Rurrenabaque on Rio Beni, 5/11 November 1956/SEMC 1204199 (SEMC); $1 \hat{0}$, Bolivia, 


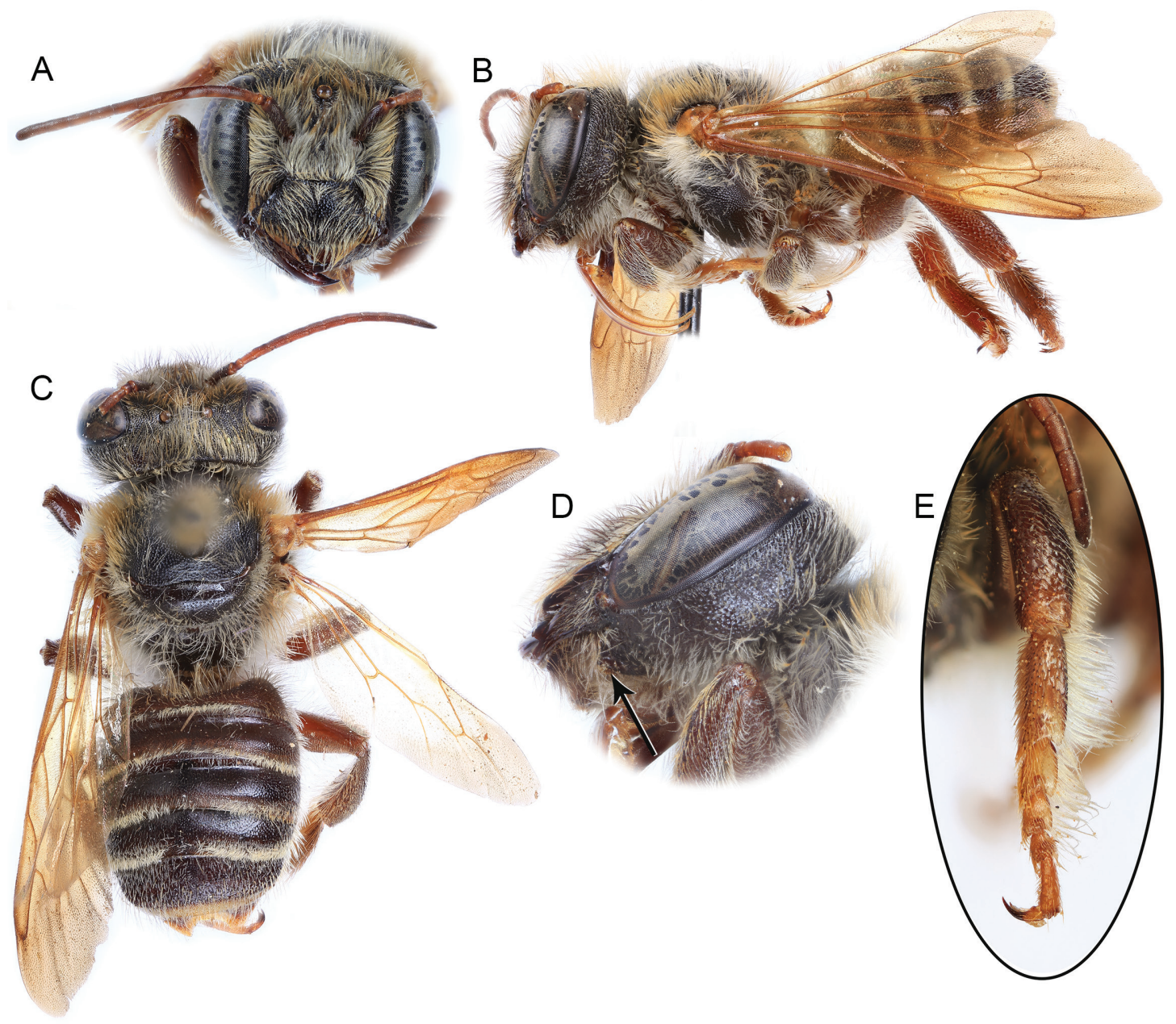

FIGURE 29. Male of Megachile (Zonomegachile) moderata Smith. A. Facial view. B. Lateral habitus. C. Dorsal habitus. D. Lateroinferior view of head. E. Outer surface of protarsus. (A-D: Brazil, Rondônia, SEMC 1178984; E: French Guiana, Kourou, SEMC 1204529).

Beni, Rurrenabaque, 175 mts, 23 October 1956 (L. Peña)/SEMC 1204248; $1 \hat{0}$, ut supra, 17 October 1956/SEMC 1179002 (SEMC); 10 , Region Chapare, Bolivia, $400 \mathrm{~m}$, VIII-1950 [August 1950], Zischka/SEMC 1178871 (SEMC). Brazil: 5 ô $\widehat{\jmath}$, Brasil, Guapore, Pimienta Bueno [Rondônia], November 1960 (M. Alvarenga)/ SEMC 1178983-85, 1178987, -88 (SEMC); 3 đิ đิ, Guapore, Abunã, Nov. '62. [1962], (W. Bokermann)/SEMC 1204891, -99, 1204906 (SEMC); 10 , ut supra, Vilhena, Nov. '60 [1960], (M. Alvarenga)/SEMC 1204792 (SEMC); 2 호,
Porto Velho, Guaporé, Brasil, XII-1954 [July 1954], M. Alvarenga/Coleção Campos Seabra/ SEMC 1179021, 1204737 (SEMC); 1 ô, ut supra, M. Alvarenga, Dente, F. Pereira e Werner/ Coleção Campos Seabra/SEMC 1204736 (SEMC). Colombia: 10 , Colombia: Amazonas, Parque Nacional Natural Amacayacu/2 km above mouth of Rio Amazonas, 4 October 1988, Fernando Fernández/SEMC 1204260 (SEMC). Ecuador: 19 , Napo Prov. Yasuni National Park, Est. La Catolica; Nov. 7-15 1998, D. Roubik No. 63 (BBSL); $1 \delta^{\text {}}$, Ecuador, Oriente, $00^{\circ} 24^{\prime} \mathrm{S}$, 
A
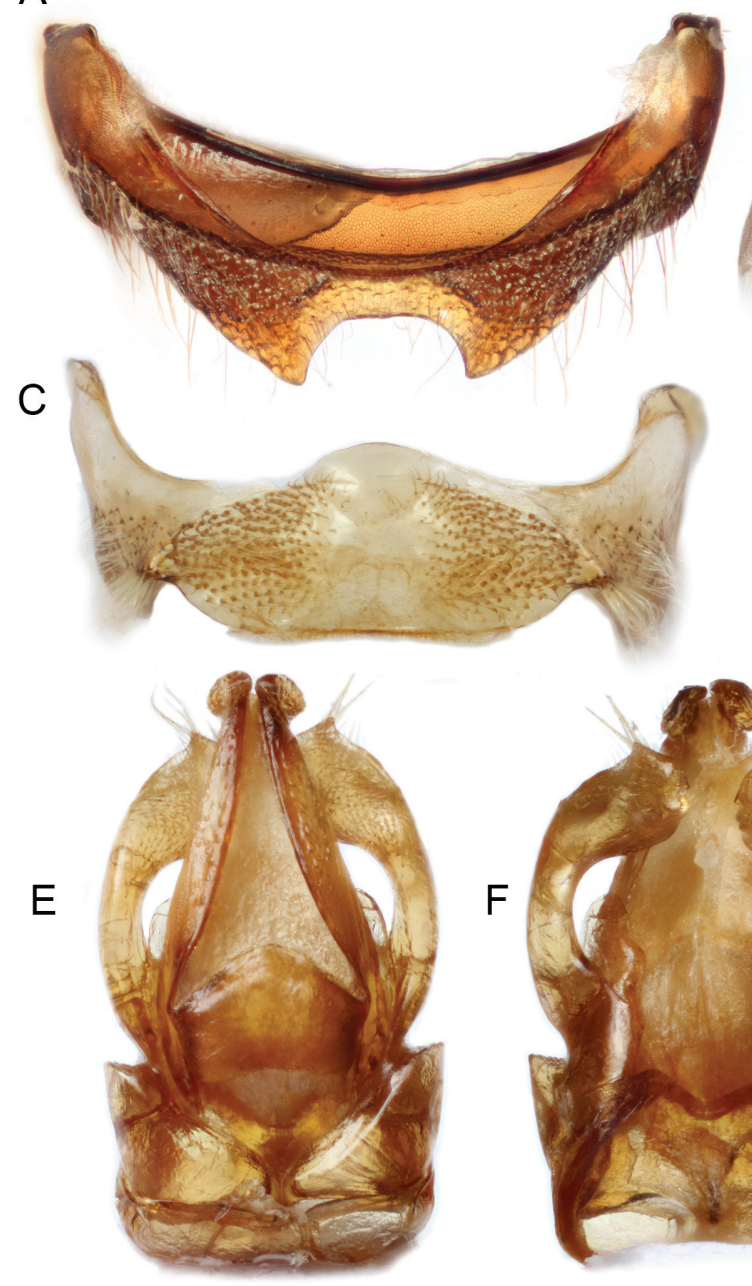

$\mathrm{F}$
$\mathrm{B}$
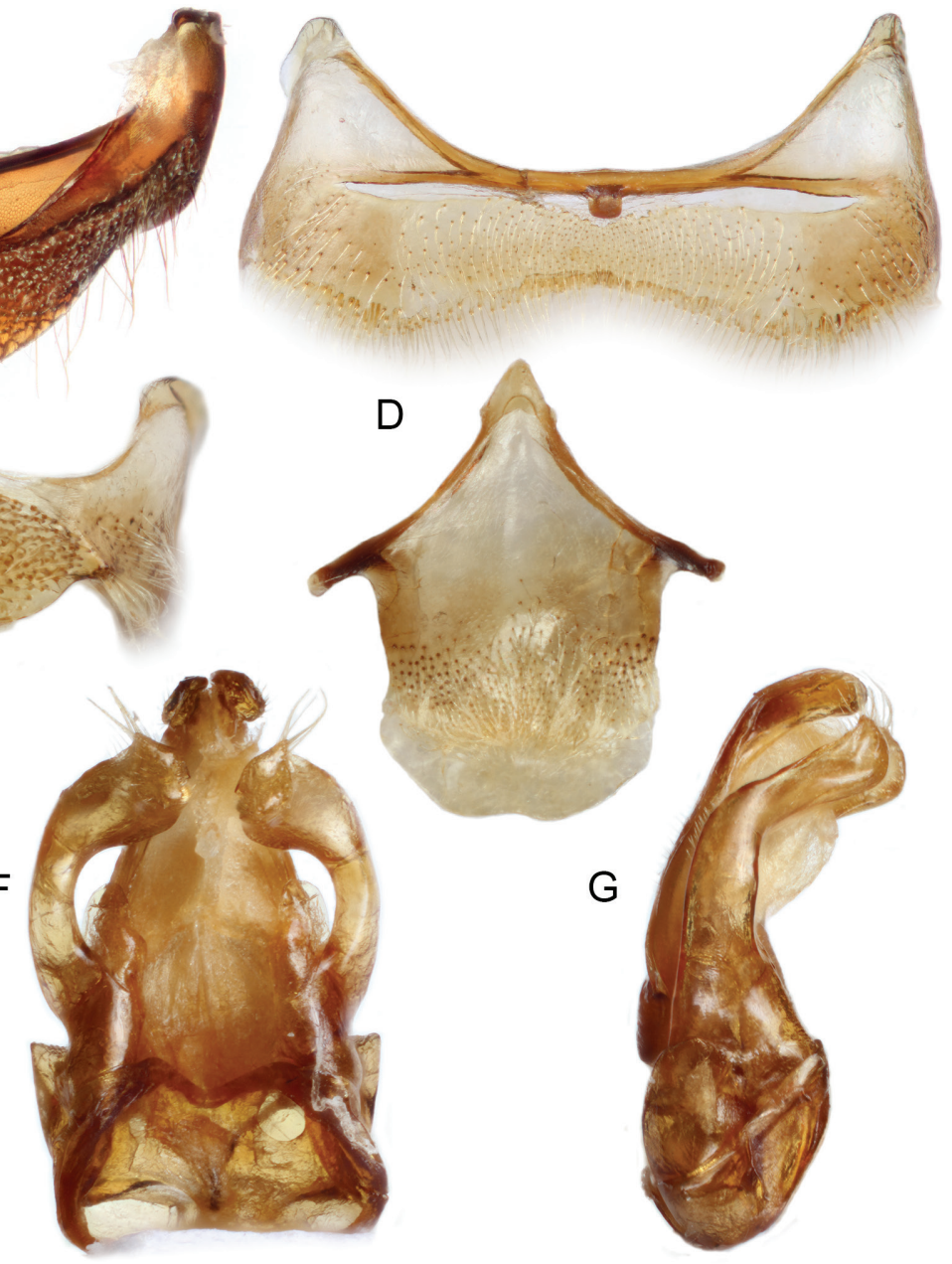

FIGURE 30. Male of Megachile (Zonomegachile) moderata Smith (French Guiana, Kourou, SEMC 1204529). A. Sixth tergum, inner view. B. Fifth sternum. C. Sixth sternum. D. Eighth sternum. E-G. Genital capsule in dorsal, ventral, and lateral views.

76³6'W, Limoncocha, 31 August 1970, M.G. Naumann, \#203/SEMC 1206099 (SEMC). French Guiana: 19 , French Guiana, Kourou, Km 6.5 SW, 29 Oct 76 [1976], D. Roubik No. 57/ SEMC 1204549 (SEMC); 3 ôे $\hat{0}$, ut supra, 2 March 1977, C.D. Michener/SEMC 1204529, -30, 178930 (SEMC); 1 ㅇ, ut supra, 13 July 1977/ SEMC 1204539 (SEMC); $1 \hat{\sigma}$, ut supra, David Roubik \#26/SEMC 1204563 (SEMC). Peru: 10 , Peru: Madre de Dios, Limonal Guard Station, Reserved Zone, Manu National Park, 350 m, $12^{\circ} 14^{\prime} 0^{\prime \prime} \mathrm{S}, 70^{\circ} 56^{\prime} 18^{\prime \prime} \mathrm{W}, 23$ Oct 2000; R. Brooks, PERU 1 B00 077, ex: on wet sand near river/ SM0258293 (SEMC).

Distribution: Bolivia, Brazil, Colombia (Amazonas), Ecuador, French Guiana, Peru (fig. 21).

Comments: The male specimens listed in the section above are tentatively associated with this species. Thus, a description is not presented at this time until this sex association can be confirmed in the field. 


\section{Megachile (Zonomegachile) nigribarbis Vachal}

Megachile nigribarbis Vachal, 1909: 6 (holotype ๙, MNHN: Mato Grosso, Brazil). Raw, 2002: 37 (placement in Zonomegachile Mitchell); Silveira et al., 2002: 215 (placement in Zonomegachile Mitchell).

Comments: This species is known only from the male holotype, which we were unable to examine. Based on the type locality, this could be the male of either M. durantae, M. reliqua Mitchell, or M. moderata, or an entirely distinct species in its own right. Pending access to the unique specimen we have been unable to further evaluate it and leave it placed in Zonomegachile, as was done by Silveira et al. (2002) and the late J.S. Moure (Moure et al., 2007).

\section{Megachile (Zonomegachile) paisa, new species}

\section{Figures 21, 31}

Diagnosis: This species can be recognized by the following combination of features: head and mesosoma mainly with light reddish-brown pubescence (fig. 31A-C); mesoscutum microalveolate to imbricate among setiferous punctures; probasitarsus robust, about $2.5 \times$ longer than broad (fig. 31D); S2 and S3 basally with white scopal setae, remaining of S3 and S4 with light reddish-brown setae, sides of S3, S4, and entire S5 and S6 with black setae. This species is most similar to M. durantae from northwestern Brazil. In addition to the geographic separation, it can be distinguished by the pubescence of the head and mesosoma, which is light reddish brown in M. paisa and whitish in M. durantae. The wings in $M$. paisa are slightly more yellow than those of $M$. durantae.

Description: Holotype, Female: As described for $M$. durantae except as follows: total body length $11.9 \mathrm{~mm}$; forewing length $10.3 \mathrm{~mm}$; head width $4.4 \mathrm{~mm}$. Interocellar distance $2.5 \times \mathrm{OD}$, about as long as ocellocular distance. Wings slightly more yellow than those of $M$. durantae. Pubescence predominantly light reddish brown on head and mesosoma except whitish on outer surfaces of tibiae. S2 and S3 basally with white scopal setae, remaining of S3 and S4 with light reddish-brown setae, sides of S3, S4, and entire S5 and S6 with black setae.

Holotype: + , Colombia: Porce. Ant. [Antioquia], (Col.), San Ignacio B, 2-4 PM, Pescado, 16/04/1997 [16 April 1997], Allan Smith P (BBSL).

Eтymology: The specific epithet is a selfreferential nickname for inhabitants of the department of Antioquia, the area where this species is currently known.

Comments: The type specimen is not in very good condition. The apical margins of the wings are strongly notched and the setae are plastered against the integument, including the white fasciae on the apical margins of the terga and sterna. Megachile paisa is exceptionally similar morphologically to $M$. durantae, differing in the color of the wings and body pubescence. Both species are known only from the female type and they could be conspecifics. However, M. paisa is known from northwestern Colombia, on the eastern slope of the Cordillera Occidental. Thus, it is on the other side of the Andes, more than $2000 \mathrm{~km}$ distant from the type locality of $M$. durantae in Rondônia, Brazil, localities that represent rather different habitats.

\section{Megachile (Zonomegachile) reliqua Mitchell, resurrected status}

Figures 21, 32

Megachile reliqua Mitchell, 1930: 260 (neotype [here designated] + , NCSU 0007194, Buenavista, Santa Cruz, Bolivia). Mitchell, 1933: 303 (placement in Melanosarus Mitchell).

Diagnosis: This species is easily recognized by the following combination of features: mesoscutum weakly imbricate, nearly smooth and shiny among setiferous punctures; dorsum of mesosoma with light reddish-brown pubescence; pro- and mesobasitarsi at least about $3.0 \times$ longer than broad (fig. 32D); and S5 and S6 with yel- 


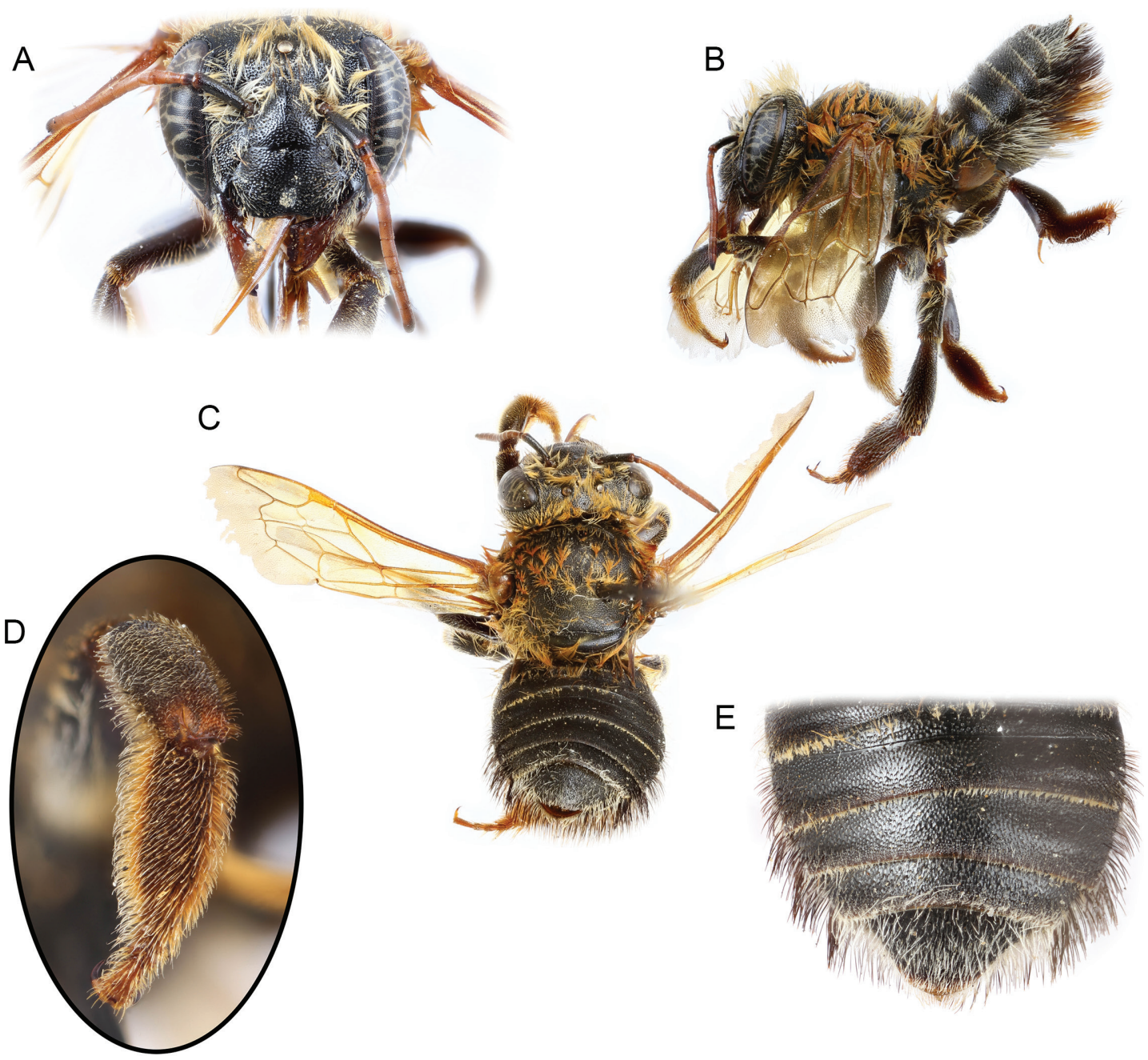

FIGURE 31. Female holotype of Megachile (Zonomegachile) paisa Gonzalez, Griswold, and Engel, new species. A. facial view. B. Lateral habitus. C. Dorsal habitus. D. Outer surface of protarsus. E. Detail of T3-T6.

lowish setae. The punctation of the mesoscutum and elongate pro- and mesobasitarsi with sparse pubescence easily distinguishes this species from all other Zonomegachile.

Description: Neotype, Female: As described for $M$. durantae except as follows: total body length $14.5 \mathrm{~mm}$; forewing length $10.8 \mathrm{~mm}$; head width $4.6 \mathrm{~mm}$. Interocellar distance $2.4 \times \mathrm{OD}$, about as long as ocellocular distance; clypeus with distal margin gently emarginate medially, nearly straight; scape $3.8 \times$ longer than broad. Probasitar- sus $3.3 \times$ longer than broad; mesobasitarsus $2.9 \times$ longer than broad; metatibia $3.4 \times$ longer than broad; metabasitarsus $3.2 \times$ longer than broad.

Body color dark reddish brown except: tegula yellowish; face, vertex, gena, mesosoma excluding legs black; discs of T2-T6 dark brown to black. Wings slightly more yellow than those of $M$. durantae.

Paraocular area, vertex, pronotal lobe, and margins of mesoscutum with yellowish setae. Sides of propodeum and terga with white setae, whitish on sides of T3 and T4. S3 and S4 basally 

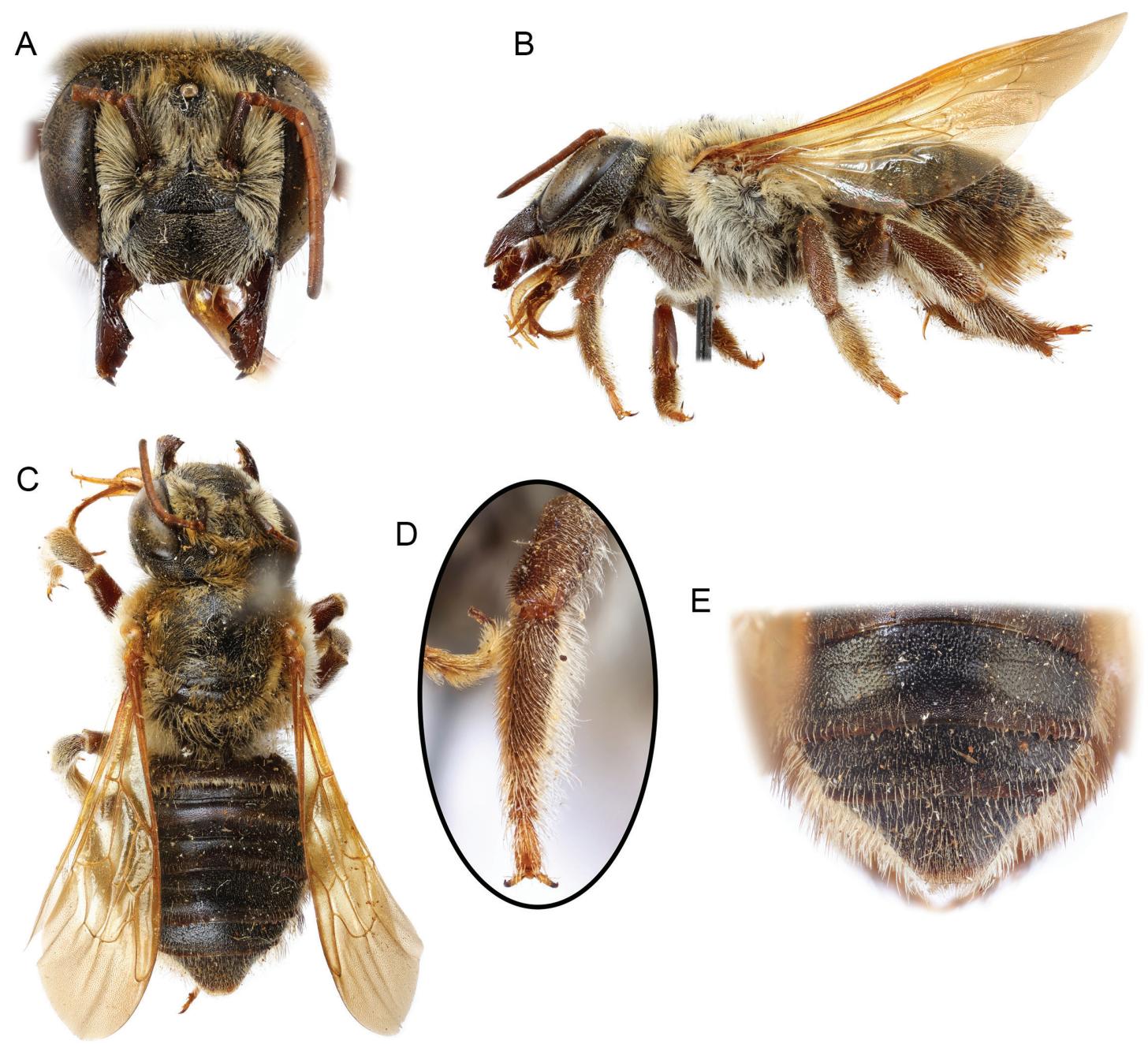

FIGURE 32. Female neotype of Megachile (Zonomegachile) reliqua Mitchell. A. Facial view. B. Lateral habitus. C. Dorsal habitus. D. Outer surface of protarsi. E. Detail of T4-T6.

with white setae, distally with light brown setae, S5 and S6 with yellowish setae. Outer surfaces of pro- and mesotibiae, and pro- and mesobasitarsi with sparser, longer setae than in $M$. durantae, not forming distinct brushes.

Head and mesosoma weakly imbricate to nearly smooth and shiny between large setiferous punctures. Clypeus and supraclypeal area more densely and coarsely punctate than in $M$. durantae.

Neоty PE (here designated): $q$, Buenavista, Dep. Sta. Cruz, Bolivia, 450 m.h./QR barcode
NCSU 0007194/Megachile reliqua Mitchell, Paratype (greenish label)/Neotype, Megachile reliqua Mitchell, des. V.H. Gonzalez, M.S. Engel, \& T. Griswold 2016. Mitchell (1930) described this species from two female specimens collected in Buenavista, Santa Cruz, Bolivia. The holotype was lost during World War II (see Material and Methods, above), and in order to stabilize the identity of the species and the name applied to it, we herein designate as neotype the only paratype. 

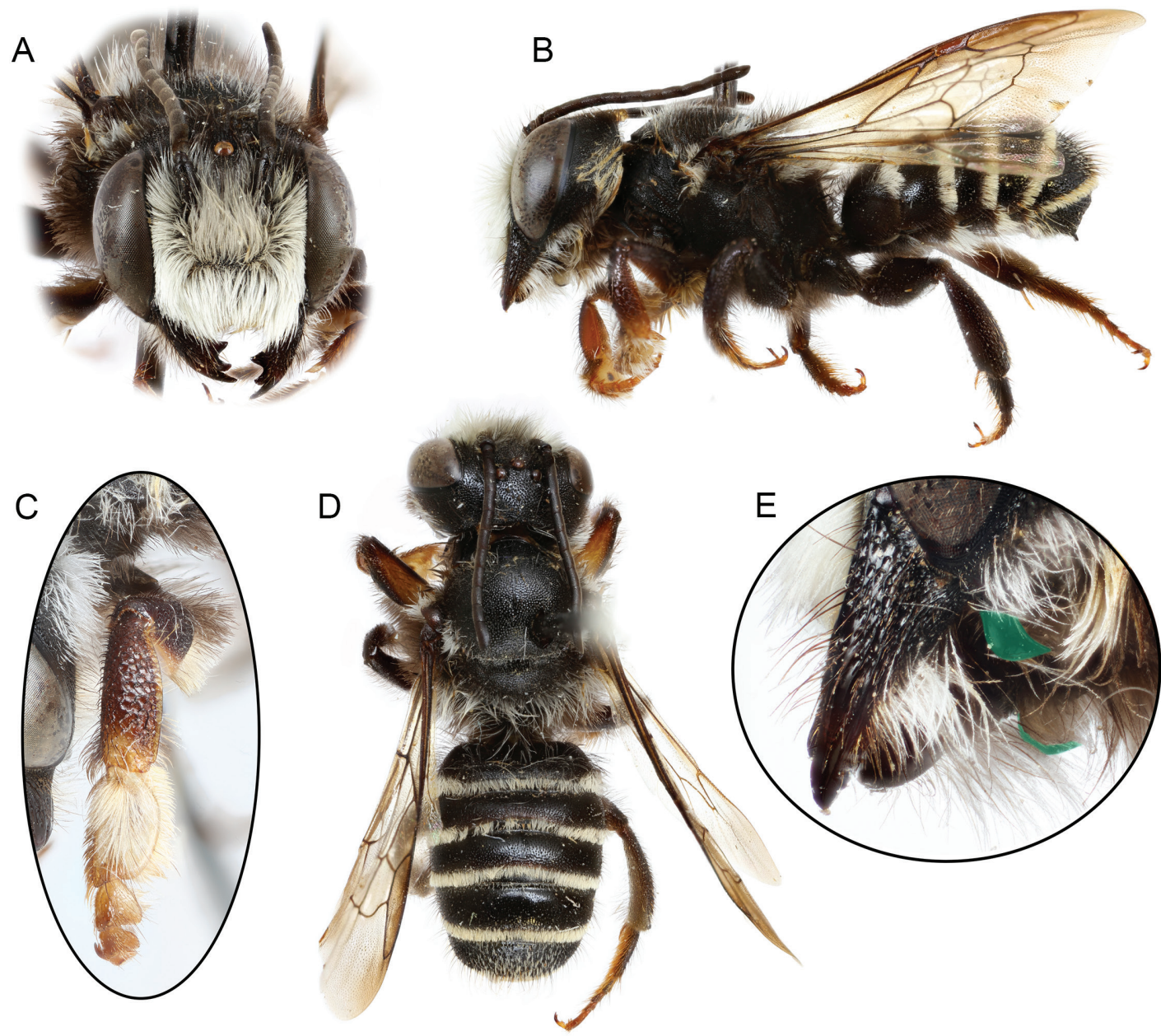

FIGURE 33. Male holotype of Megachile (Zonomegachile) uncinata Gonzalez, Griswold, and Engel, new species, except paratype in figures C and E. A. facial view. B. Lateral habitus. C. Outer surface of protibia and protarsi. D. Dorsal habitus. E. Detail of hypostomal area showing hook (highlighted in green).

Additional material eXamined: 19 , Brasil: Guapore, Pimienta Bueno, November 1960 (M. Alvarenga)/SEMC 1204767 (SEMC).

Distribution: Bolivia (Santa Cruz), Brazil (Rio Grande do Sul) (fig. 21).

\section{Megachile (Zonomegachile) uncinata, new species}

Figures 21, 33, 34

Diagnosis: This species is known only from the male sex. It can be easily recognized by the follow- ing combination of features: hypostomal tooth posteriorly directed, strongly curved (fig. 33E); protibia with posterior margin carinate; probasitarsus about twice as long as broad, distinctly expanded posteriorly (fig. 33C); and preapical carina of T6 narrow, on middle one third of tergum (fig. 34A). In all other species of Zonomegachile the hypostomal tooth is anteriorly directed, straight, the posterior margin of the protibia is rounded, the probasitarsus is more elongate, parallel-sided, and the preapical carina of $\mathrm{T} 6$ is broader, occupying about the median half of the tergum. 

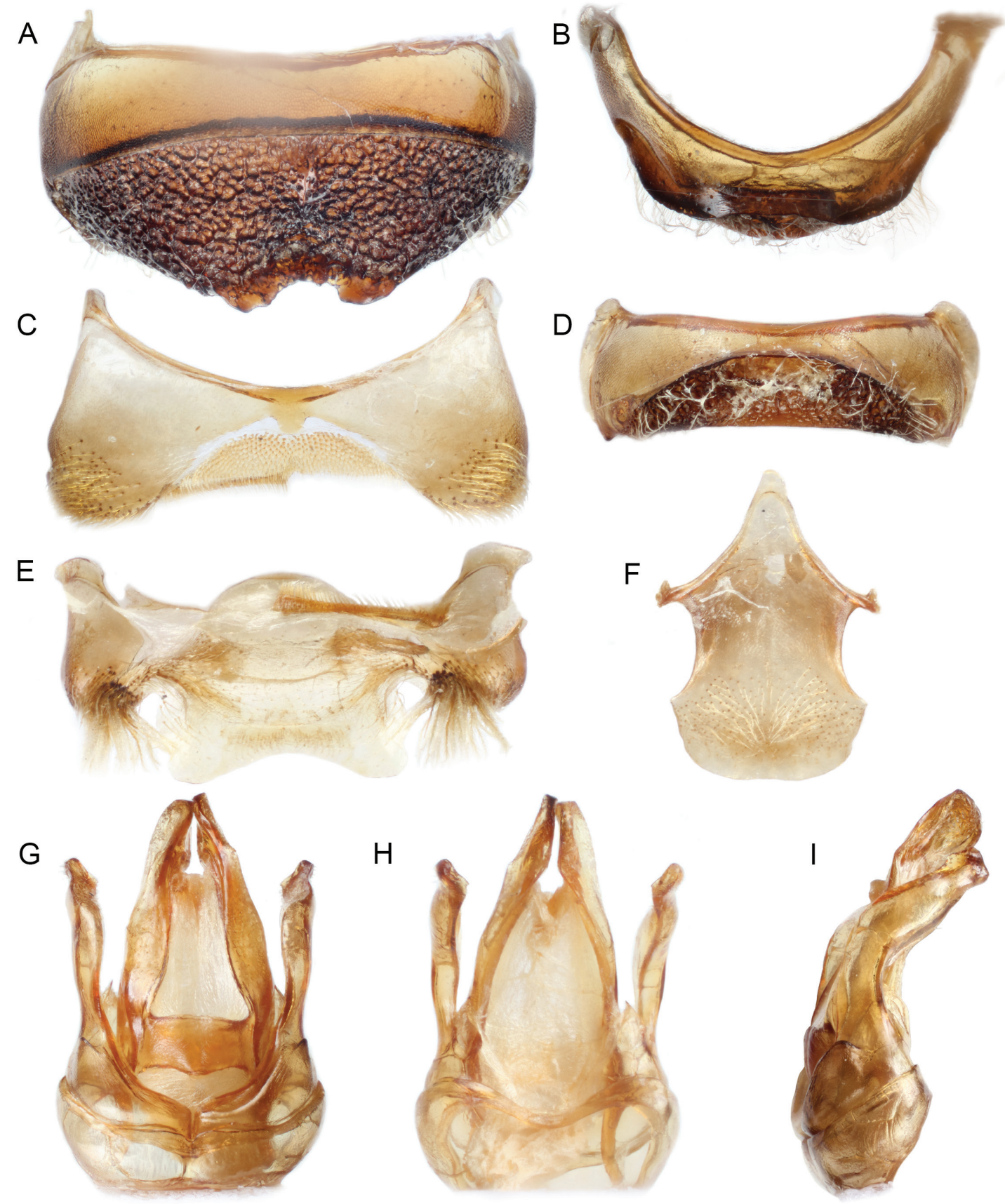

FIGURE 34. Male paratype of Megachile (Zonomegachile) uncinata Gonzalez, Griswold, and Engel, new species. A. Sixth tergum in dorsal view. B, D. Seventh tergum in dorsal and ventral views. C. Fifth sternum. E. Sixth sternum. F. Eighth sternum. G-I. Genital capsule in dorsal, ventral, and lateral views. 
DESCRIPTION: Holotype (paratype in parentheses), Male: total body length 11.5 (12.3) mm; forewing length $8.5(8.5) \mathrm{mm}$; head width 3.8 (3.9) $\mathrm{mm}$. Head $1.3 \times$ wider than long; inner orbits of compound eyes straight or nearly so; intertorular distance $1.3 \times$ times torulorbital distance; interocellar distance $2.1 \times \mathrm{OD}, 0.9 \times$ ocellocular distance; ocelloccipital distance $3.2 \times \mathrm{OD}$, $1.5 \times$ ocellocular distance; scape $2.1 \times$ longer than broad, pedicel shorter than F1, slightly broader than long, F1 1.1× longer than broad, shorter than F2, remaining flagellomeres longer than broad, distalmost flagellomere slightly compressed and expanded. Clypeus straight or nearly so on distal margin; hypostomal area anteriorly with strong, posteriorly projected tooth, hidden by dense pubescence in frontal view, with distinct cavity posterior to tooth. Procoxa with apical spine long, about $1.5 \times \mathrm{OD}$; protibia with posterior margin carinate; probasitarsus expanded, convex on posterior margin, about twice as long as broad; mesobasitarsus $2.5 \times$ longer than broad; metabasitarsus $3.5 \times$ longer than broad. Preapical carina of T6 on middle onethird of tergum, shallowly emarginate medially, about $3.0 \times$ broader than deep, tooth lateral to emargination small, acute (larger and blunt in the paratype). Genital capsule and associated terga and sterna as in figure 34 .

Body color black, except: dorsal and ventral surfaces of profemur, and inner surface of protibia yellow; anterior surface of protibia, and meso- and metadistitarsi light reddish brown; protarsi yellowish, slightly darkened on apical podites. Tegula dark brown to black; wings brownish, darker anterior half of marginal cell; pterostigma and veins dark brown.

Pubescence dark grayish brown except: face, gena, hypostomal concavity, inferior margin of mandible, pronotum dorsally, pronotal lobe, anterior margin of mesoscutum, preaxilla, mesoscuto-mesoscutellar suture, metanotum, propodeum posteriorly, outer surfaces of protarsi, discs of T1 and T5, and apical fasciae of T1-T5 and S1-S3 with white setae; profemur basally and inner surfaces of all tarsi with light reddish-brown setae. Hypostomal concavity bordered posteriorly by stiff setae. Procoxa ventrally, near spine, with stiff, thick light reddishbrown setae, apex of spine with tuft of shorter, denser, thinner, light reddish-brown setae; protarsi with dense fringe of short setae along their posterior margin, at most $0.6 \times$ width of basitarsus; mesotarsi with sparser, longer fringe of setae than on protarsi, about $3.0 \times$ longer than width of mesobasitarsus; posterior surface of metafemur, near dorsal margin, with tuft of keirotrichial setae. Apical fascia on sterna longer and sparser than on terga.

Face and vertex coarsely and densely punctate, punctures contiguous except on vertex behind ocelli; gena superiorly with smaller, shallower punctures than on vertex, punctures becoming coarser inferiorly. Mesoscutum weakly imbricate, shiny, with coarse, larger punctures than on vertex, separated by at most a puncture width on disc; mesoscutellum and axilla with denser punctures than on mesoscutum, nearly contiguous on axilla; mesepisternum alveolate, alveoli larger than punctures on mesoscutum; metepisternum and lateral and posterior surfaces of propodeum strongly imbricate, punctures on metepisternum separated by at most a puncture width, punctures smaller and closer on lateral surface of propodeum, becoming sparser $(\geq 2.0 \times \mathrm{PW})$, shallower on posterior surface of propodeum; propodeal triangle microalveolate; metanotum strongly imbricate with smaller, shallower, and denser punctures than on mesoscutellum; legs weakly imbricate to smooth and shiny with coarse punctures on outer surfaces of tibiae. Terga weakly imbricate to smooth and shiny, minutely and sparsely punctate (1.0-3.0× PW), punctures coarser and denser on T5; T6 foveate, with sharp borders among fovea; sterna more strongly imbricate and with sparser punctures than on terga.

Female: Unknown.

Holotype: đิ, ARG [Argentina]: Catamarca, Colpes, 15 km S, X-27-72 [27 October 1972], G.E. Bohart/Zuccagnia punctata (BBSL). 
Paratype: 10 , ARG [Argentina]: S.D. Estero [Santiago del Estero], Las Termas, X-11-72 [11 October 1972], G.E. Bohart/Prosopis alba (BBSL).

Eтymology: The specific epithet is from the Latin uncinus meaning "hook," in reference to the curved, posteriorly directed projection of the hypostomal area that characterizes the male of this species.

FLORAL RECORDS: This species has been collected on flowers of Prosopis alba Griseb. and Zuccania punctata Cav., both in the family Fabaceae.

Comments: We assigned this species to Zonomegachile based on the presence of a hypostomal projection. However, the shape of the genital capsule and associated sterna does not suggest a close relationship to the other species of the group and it might belong to a different subgenus, pending discovery of the female. For the moment, this is the most conservative placement for the species.

Key to Species of Zonomegachile

\section{Females}

(Female of M. uncinata unknown)

1. T1-T4 with dense, appressed, broad apical yellow fasciae; legs orange

M. gigas Schrottky

- T1-T4 with dense or sparse, appressed, narrow apical whitish fasciae; legs dark reddish brown (figs. 24, 28) 2

2(1). Discs of mesoscutum and mesoscutellum weakly imbricate to nearly smooth and shiny between large setiferous punctures; mandible mainly dark reddish brown; proand mesobasitarsi sparsely setose, elongate, each at least about $3.0 \times$ longer than broad (fig. 32D); S6 scopal setae yellowish

M. reliqua Mitchell

-Discs of mesoscutum and mesoscutellum dull, microalveolate between large setiferous punctures; mandible largely light reddish brown to orange except for black mandibular margin; pro- and mesobasitarsi densely setose, robust, each at most $2.5 \times$ longer than broad (figs. 4F, 24C, 31D); S6 scopal setae largely dark brown to black ....................3

3(2). Disc of T5 uniformly punctate, punctures rounded, separated at most by a puncture width (fig. 24E); S3-S5 with mostly dark grayish-brown to black setae, each with a row of yellowish setae basally (mandible largely orange) .................... M. kalina, n. sp.

-Disc of T5 not uniformly punctate, punctures elongate, separated by at least a puncture width (fig. 28E); S3 and S4 with mostly yellowish or light reddish-brown scopal setae, dark grayish-brown setae on sides only; S5 variable, with either mostly yellowish or mostly dark grayish scopal setae (mandible often light reddish brown)

4(3). S5 with mostly yellowish scopal setae, dark grayish-brown setae on sides only M. moderata Smith

-S5 with dark grayish-brown to black setae as on S6 5

5(4). Head and mesosoma excluding legs with predominantly light reddish-brown setae (fig. 31) (Northwestern Colombia [Antioquia]) M. paisa, n. sp. - Head and mesosoma excluding legs with predominantly whitish setae (fig. 21) (Brazil [Rondônia]) ................... M. durantae, n. sp.

\section{MALES}

(Males of M. durantae, M. paisa, and $M$. reliqua unknown)

1. T1-T4 apically, T3 and T4 basally and nearly entire disc of T5 with dense, appressed, yellow fasciae; legs orange (fig. 23) M. gigas Schrottky

- T1-T4 with dense or sparse, appressed apical whitish fasciae; legs dark reddish brown (figs. 25, 29) 2

2(1). Hypostomal tooth strongly curved, posteriorly directed (fig. 33E); protibia with poste- 
rior margin carinate; T6 with preapical carina on middle one third of tergum (fig. $34 \mathrm{~A}$ ), with small concavity just above carina (Argentina [Catamarca, Santiago del Estero]) M. uncinata, n. sp. -Hypostomal tooth straight, anteriorly directed, not curved (figs. 5G, 25D, 29D); protibia with posterior margin rounded, not carinate; T6 with preapical carina broader, on median half of tergum (fig. 6A), without concavity above carina broadly .3

3(2). Hypostomal tooth strong, distinct in frontal view (fig. 25A, D); inferior margin of mandible basally with white, branched setae; procoxa with apical spine long, about $1.5 \times$ OD; probasitarsus slightly expanded posteriorly, about $2.3 \times$ longer than broad, with distinct fringe of dense setae (fig. 25E) ......... M. kalina, n. sp.

- Hypostomal tooth not as strong as above, not distinct in frontal view (fig. 29A, D); inferior margin of mandible basally with dark gray or black branched setae; procoxa with apical spine short, about as long as OD; probasitarsus not or barely expanded posteriorly, about $2.7 \times$ longer than broad, with sparser fringe (fig. 29E)

M. moderata Smith

\section{Key to Subgenera of Megachile S.L. of the Western Hemisphere}

The following keys are modified from Michener (2007). To facilitate comparisons, they also follow Michener's (2007) subgeneric classification, except for the subgenera Austrosarus Raw and Stelodides Moure, which are herein included in Chrysosarus, as proposed by Gonzalez (2013).

\section{Females}

(The females of Aporiochile and Chalepochile are unknown)

1. Mandible with interdental laminae (figs. 2, $3 \mathrm{C}-\mathrm{F}$ ), if in second interspace only, then lamina complete (entirely filling interspace), or mandible clearly five-toothed, with $\mathrm{Mt}_{4}$ and $\mathrm{Mt}_{5}$ about as apart as $\mathrm{Mt}_{3}$ and $\mathrm{Mt}_{4} \ldots \ldots \ldots .2$

-Mandible without (fig. 3A) or with scarcely evident interdental laminae as seen in frontal view (fig. 1A), or with incomplete interdental lamina in second interspace only; mandible with less than five teeth, or, if fivetoothed, then upper two teeth $\left(\mathrm{Mt}_{4}\right.$ and $\left.\mathrm{Mt}_{5}\right)$ usually closer than $\mathrm{Mt}_{3}$ and $\mathrm{Mt}_{4} \ldots \ldots \ldots . . . .8$

2(1). S6 with at least posterior half bare or nearly so, except for subapical row of short setae, behind which is a bare, smooth rim directed posteriorly (fig. 5B) ..................................

-S6 with well dispersed scopal setae (fig. 5A), or, if partly bare, then without bare apical rim behind transverse fringe of short setae or (in Argyropile Mitchell) rim directed upward, or rim narrow and barely recognizable ............... 18

3(2). Mandible five-toothed, a long interdental lamina in second interspace, none elsewhere Melanosarus Mitchell

-Mandible four-toothed, a well-formed interdental laminae in third interspace ........... 4

4(3). Second interspace distinct (fig. 3E), with interdental laminae usually present; apex of $\mathrm{Mt}_{3}$ usually acute

5

-Second interspace lacking or small, without a distinct interdental lamina; apex of $\mathrm{Mt}_{3}$ usually truncate 7

5(4). Inner angle of mandible truncate, or apical margin of clypeus impressed medially; S6 with distal margin rather narrowly truncate Moureapis Raw

- Inner angle of mandible acute or rounded; clypeal margin not deeply impressed medially, slightly medially emarginate to straight and entire; S6 with distal margin broadly truncate or rounded

6(5). Second interspace shorter than third, with small, often inconspicuous interdental lamina; apical margin of clypeus slightly emarginate medially ......... Leptorachis Mitchell (in part) [M. (L.) crotalariae Schwimmer] -Second interspace about as long as third, with distinct interdental lamina; clypeal margin 
straight and entire

Pseudocentron Mitchell

7(4).Mandible robust, apical tooth more protuberant, much broader than other teeth (fig. $3 \mathrm{C})$; gena usually broader than compound eye in lateral view ....... Acentron Mitchell

-Mandible less robust, apical tooth not much broader than second or third; gena usually narrower than compound eye in lateral view Leptorachis Mitchell (in part)

8(1). Mandible with a distinct incomplete interdental lamina in second interspace, and no lamina elsewhere, or with scarcely evident interdental laminae in second and third interspaces .. 9

-Mandible without interdental laminae in second and third interspaces ..................... 12

$9(8)$. Body very large and robust $(20 \times 10 \mathrm{~mm})$; pubescence entirely fulvous (mandible with first interspace small or lacking, second and third narrow and angled, not semicircular, upper tooth truncate; Mexico)

Grosapis Mitchell

-Body not so large and robust; pubescence usually not entirely fulvous (body pubescence fulvous in M. (Sayapis) palmeri Cresson but all mandibular interspaces distinct, semicircular, and upper tooth acute) ............ 10

10(9). Preoccipital carina distinct behind gena Rhyssomegachile Mitchell (in part)

-Preoccipital margin of gena not carinate ... 11

11(10). T6 straight or nearly so in profile; sterna with incomplete white apical fascia beneath scopa; apex of protibia without a distinct acute spine on outer surface

Chrysosarus Mitchell (in part)

-T6 usually strongly concave in profile; sterna usually without apical fascia beneath scopa; apex of protibia with a distinct acute spine on outer surface ................. Sayapis Titus

12(8). Apex of protibia without distinct acute spine on outer surface 13

-Apex of protibia with at least one distinct acute spine on outer surface .. 14

13(12). T6 distinctly concave in profile, without conspicuous erect pubescence except near base; body pubescence largely white or gray; metasomal sterna without white fasciae beneath scopa (Holarctic) ...

Megachile Latreille s.str. (in part)

- T6 nearly straight or concave in profile, with abundant erect pubescence; body pubescence of variable color; metasomal sterna with white fasciae beneath scopa absent or broadly interrupted medially (Neotropical) Chrysosarus Mitchell (in part)

14(12). Body very large and robust (> $18 \mathrm{~mm}$ in length); pubescence with large areas of black or fulvous setae; apex of protibia with two or three spines on outer surface (adventive) ......15

-Body not so large and robust $(\sim 15 \mathrm{~mm}$ in length); pubescence largely white, not fulvous; apex of protibia with only one acute spine on outer surface 17

15(14). Apex of protibia with three distinct sharp spines or teeth on outer surface; clypeus with longitudinal elevation, highest at lower clypeal margin (Jamaica)

Gronoceras Cockerell

-Apex of protibia with two teeth and spines on outer surface; clypeus unmodified or not modified as above 16

16(15). Mandibular carinae minutely roughened, sometimes dull; adductor interspace of inner surface of mandible covered with very small $(\leq 0.2 \times$ OD) appressed setae. Callomegachile Michener

-Mandibular carinae shining and smooth (at 40x); adductor interspace of inner surface of mandible sparsely covered with longer setae $(\geq 0.4 \times$ OD) Pseudomegachile Friese

17(14). Pronotal lobe with asetose transverse lamella hidden among setae; mandible with third interspace narrowly U-shaped and much deeper than others; clypeus with a strong, bifid median process extending down over base of labrum

Schrottkyapis Mitchell

- Pronotal lobe with transverse, unusually setose ridge, sometimes with shiny low carina; mandible with third interspace not narrower and deeper than others; clypeus unmodified 
or not modified as above

Chelostomoides Robertson

18(2). Mandible three-toothed or median tooth weakly divided and mandible thus obscurely four-toothed, with interdental lamina limited to upper interspace (second if mandible is tridentate, third if mandible is quadridentate) (Nearctic)

Megachiloides Mitchell (in part)

-Mandible four- or five-toothed, with interdental laminae in third and usually second interspaces 19

19(18). Mandible robust, apical tooth more protuberant, much broader than other teeth ...... 20

-Mandible less robust, apical tooth not much broader than second or third .................. 22

20(19). S6 with apical rim directed upward beyond fringe of setae, this rim conspicuous if tergum and sternum are spread apart; middle tarsomeres with conspicuously narrow bases, if anterodistal margin projected, projection slender and elongate

Argyropile Mitchell

- S6 without apical rim directed upward beyond fringe of setae, or, if apical margin is swollen as in $M$. (Xanthosarus) fortis Cresson, bases and anterodistal projections of middle tarsomeres broad and acutely angulate, not elongate ...... 21

21(20). T6 straight in profile; mandible with second tooth often rounded or obtuse; usually no interdental lamina in second interspace Megachiloides Mitchell (in part)

- T6 straight or concave in profile; mandible with second tooth usually acute; often with small incomplete interdental lamina in second interspace

Xanthosarus Robertson (in part)

22(19). Mesosomal venter, including leg bases and S2, with dense covering of fine, plumose setae, sharply differentiated from other scopal setae Ptilosarus Mitchell

-Mesosomal venter and leg bases with ordinary setae, scopal setae all unbranched

23(22). Metasomal sterna with entire and conspicuous white apical fasciae beneath scopa
- Metasomal sterna with white apical fasciae absent or broadly interrupted medially, except on S5 25

24(23). Mandible four-toothed, no interdental lamina in second interspace (adventive, North America, Antilles, Chile, and Argentina) ...................... Eutricharaea Thomson

-Mandible with fourth tooth emarginate, thus five-toothed, second interspace with conspicuous but incomplete interdental lamina (South America) ....... Trichurochile Mitchell

25(23). Mandible four-toothed, upper tooth acute or right-angular 26

-Mandible four- or five-toothed but if fourtoothed, then upper tooth rounded, truncate, or incised (sometimes only minutely) and thus approaching five-toothed condition

26(25). Metasoma broadly conical, T3 narrower than T1 or T2 (Neotropical) Tylomegachile Moure (in part)

-Metasoma more ovoid, T3 as broad as T1 ... 27 27(26). Scopa black; body usually covered with long, dense setae sometimes obscuring integument and not forming pale apical tergal fasciae, producing a Bombus-like aspect, or, if rather ordinary looking species, then clypeus and supraclypeal area flat and dull, with abundant erect, short, and partly hooked setae (primarily Andean)

Dasymegachile Mitchell (in part)

-Scopa brownish, yellowish or white except on S6; body not densely covered with long, dense setae; clypeus and supraclypeal area not flat, shiny, and without hooked setae ............ 28 28(27). Interdental laminae in both second and third interspaces incomplete, that of second only very slightly depressed below level of interspace margin; T6 straight in profile (South America) ... Zonomegachile Mitchell

-Third interspace with complete interdental lamina; second interspace with incomplete interdental lamina, distinctly below level of interspace margin; T6 straight or preapically concave in profile (Nearctic) Litomegachile Mitchell 
29(25). Scopa black; body usually covered with long, dense setae sometimes obscuring integument and not forming pale apical tergal fasciae, producing a Bombus-like aspect, or, if rather ordinary looking species, then clypeus and supraclypeal area flat and dull, with abundant erect, short, and partly hooked setae (primarily Andean)

Dasymegachile Mitchell (in part)

-Scopa variable in color, black with brightly reddish setae on S3-S5, brownish or white, except on S6; body usually not densely covered with long, dense setae; clypeus and supraclypeal area not flat, shiny, and without hooked setae 30

30(29). Mandible clearly five-toothed, distance between upper two teeth not or only slightly less than distance between other pairs of teeth (Holarctic)

Megachile Latreille s.str. (in part)

-Mandible four-toothed but upper tooth rounded, truncate, or itself bidentate (sometimes minutely), mandible thus five-toothed but distance between upper two teeth short compared to distances between other pairs of teeth

31(30). Metasoma distinctly conical, T1 and T2 broader than $\mathrm{T} 3$ 32

- Metasoma more ovoid, T3 as broad as or broader than $\mathrm{T} 1$ 33

32(31). Metasomal sterna with widely interrupted apical white fasciae beneath scopa; posterior apical angle of metabasitarsus (metatarsomere 1) slightly produced, that of metatarsomere 2 more conspicuously so (preoccipital margin of gena usually with distinct carina or sharp border) ................ Austromegachile Mitchell (in part) [M. (A.) exaltata Smith]

-Metasomal sterna not at all fasciate; metatarsomeres 1 and 2 not or little produced apically .............. Tylomegachile Moure (in part)

33(31). Median area of clypeus somewhat elevated and strongly flattened, sloping away on each side (apical margin of clypeus medially emarginate)

Austromegachile Mitchell (in part)
-Clypeus broadly convex or nearly flat, neither elevated nor flat medially ........................... 34

34(33). Pubescence of T6 conspicuous, with many erect setae as seen in profile ............ 35

-Pubescence of T6 largely decumbent, with few or no erect setae visible in profile ............ 36

35(34). Lateral ocellus considerably nearer to posterior margin of vertex than to compound eye ................. Cressoniella Mitchell

- Lateral ocellus usually as near as or nearer to compound eye than to posterior margin of vertex ........ Xanthosarus Robertson (in part) 36(34). Preoccipital carina distinct behind gena (also along vertex in M. guayaqui Schrottky); interdental laminae of mandible obsolete, hidden behind interspace margin (fig. 1); ocelloccipital distance greater than ocellocular distance

Rhyssomegachile Mitchell (in part)

-Preoccipital margin of gena usually not carinate, but if so, then interdental laminae of mandibles wellformed and easily recognized in frontal view; ocelloccipital distance shorter than ocellocular distance ............... 37

37(36). Mesosoma and metasoma densely and minutely punctate throughout, largely covered with appressed or suberect tomentum; integument of metanotum largely visible among setae; apical terga densely covered by appressed, yellowish tomentum and thus contrasting with color of preceding terga ....

Ptilosaroides Mitchell

-Mesosoma and metasoma with punctures distinctly separated, surface not tomentose to any considerable degree; integument of metanotum hidden by dense tomentum; apical terga without appressed, yellowish tomentum, with pubescence as on preceding terga ............................ Neochelynia Schrottky

\section{Males}

1.Mesotibial spur absent or much shorter than apical width of mesotibia, sometimes immovably fused to mesotibia, and mesobasitarsus not or little modified 2 
-Mesotibial spur present, articulated to mesotibia, about as long as apical mesotibial width, or, if absent (as in some Xanthosarus Robertson), then mesobasitarsus modified and swollen ... 8

2(1).Mesotibial spur present, articulated but small Leptorachis Mitchell

-Mesotibial spur absent or represented by prong immovably fused to mesotibia 3

3(2). Preoccipital carina strong behind genal area; T6 with weak, inconspicuous preapical carina; mesepisternum ventrally with deep longitudinal groove and short, dense, appressed pubescence ......... Austromegachile Mitchell (in part) [M. (A.) exaltata Smith] -Preoccipital carina absent; T6 often with strong preapical carina medially emarginate; mesepisternum ventrally unmodified, covered with longer, sparser, erect setae 4

4(3). Mesotibia with a spur-like apical prong (spur presumably fused to mesotibia), prong sometimes reduced to large, acute tooth ...... Pseudocentron Mitchell

- Mesotibia without such a process ... 5

5(4). Procoxa with spine; mandible with strong basal process on lower margin (fig. 5E, F) ..... 6

-Procoxa without a spine; mandible without basal process on lower margin Cressoniella Mitchell (in part) [M. (C.) grandibarbis Pérez] 6(5). Pro- and mesotibiae and pro- and mesotarsi simple and unmodified; protarsus slender, usually black (except in M. possograndensis Schrottky) Moureapis Raw

-Pro- and mesotibiae and pro- and mesotarsi modified; mesotibia broadened apically or angulate on lower margin; mesobasitarsus usually excavated along anterior margin; protarsus dilated and brightly colored ....... 7

7(5). Mesoscutum finely and densely rugosopunctate, punctures not individually distinguishable; mesocoxa usually with small spine Acentron Mitchell

- Mesoscutum with punctures usually well separated, but if close, then individually dis- tinguishable; mesocoxa without spine Melanosarus Mitchell

8(1). S4 not exposed or only its posterior margin exposed; punctation and vestiture of S4 (except sometimes for posterior margin) reduced and different from those of S3 ...... 9

-S4 exposed; punctation and vestiture of S4 similar to those of S3 10

9(8). Mandible three-toothed, tooth margin much shorter than distance from upper tooth to base of mandible; body not so large and robust $(<17$ $\mathrm{mm}$ in length); body pubescence largely white or gray ................. Chelostomoides Robertson

-Mandible four-toothed, elongate, toothed margin as long as distance from upper tooth to base of mandible; body very large and robust $(20 \times 10 \mathrm{~mm})$; pubescence entirely fulvous (Mexico) .. Grosapis Mitchell

10(8). Pronotal lobe with erect, bare transverse lamella (clypeus protuberant medially; mandible as described above for Grosapis Mitchell) Schrottkyapis Mitchell

- Pronotal lobe rounded or with transverse, usually setose ridge, sometimes with shiny, bare, but low carina . 11

11(10). S8 with setae on lateral margins; body chalicodomiform with large areas of black and fulvous setae forming a striking color pattern (except in our species of Gronoceras Cockerell: introduced into Caribbean region) 12

-S8 usually without marginal setae (fig. 9E) but discal setae sometimes extending laterally beyond margin; body usually megachiliform and usually without striking color pattern (except in M. (Chrysosarus) euzona Pérez). 14

12(11). T6 with preapical brush of long setae and two long, slender spines representing preapical carina ................. Gronoceras Cockerell

- T6 without brush of long setae and without long spines ................................................. 13 13(12). T6 with carina short, low, not or shallowly emarginate, not denticulate Callomegachile Michener 
- T6 with carina strong, strongly dentate or denticulate, or sometimes scarcely undulate ......

Pseudomegachile Friese

14(11). Mandible without inferior projection or tooth 15

-Mandible with a definite projection, tooth, or angle on lower margin ........................... 28

15(14). Procoxal spine present ............................ 16

-Procoxal spine absent ................................... 21

16(15). Procoxal spine short, inconspicuous; F1 shorter than pedicel; T6 projecting posteriorly, thus nearly horizontal above carina (small, slender species)

Neochelynia Schrottky (in part)

-Procoxal spine longer, conspicuous; F1 of variable length, shorter or longer than pedicel; T6 more nearly vertical, usually not visible from above 17

17(16). Carina of T6 without emargination but with small median apical point (Neotropical) Tylomegachile Moure

- Carina of T6 variable, with a deep, rounded emargination, with a pair of acute spines or teeth, or crenulate to multidentate ............ 18

18(17). Preoccipital carina strong behind genal area (protarsus tarsus slender, dark) Aporiochile Gonzalez and Engel, n. subgen.

-Preoccipital carina absent 19

19(18). Hypostomal area, immediately behind mandible, with strong, angular or curved projection (fig. 5G) (South America) Zonomegachile Mitchell

- Hypostomal area not modified as above (Central and South America) 20

20(19). T6 with preapical carina reduced to two spines, one on each side of emargination; mandible four-toothed; protarsus slender, black Ptilosaroides Mitchell

- . T6 with preapical carina better developed, not reduced to two spines; mandible threetoothed; protarsus usually enlarged, pale . Chrysosarus Mitchell (in part)

21(15). F1 and F2 subequal in length (mandible three-toothed, middle tooth sometimes notched, suggesting a four-toothed condi- tion) (primarily Andean)

Dasymegachile Mitchell

-F1 shorter than F2 22

22(21). Carina of T6 with a pair of acute spines or teeth, or with median emargination filled by dense fringes of long, plumose setae .... 23

-Carina of T6 not bispinose, median emargination, if present, not filled by dense fringes of long, plumose setae and lateral portions of each side of emargination obtuse

23(22). Carina of T6 with large emargination between teeth filled by dense fringes of long, plumose setae largely arising from teeth (mandible three-toothed)

Trichurochile Mitchell

-Carina of T6 with emargination between teeth not filled by fringe 24

24(23). Mandible four-toothed; body length often $12 \mathrm{~mm}$ or more; pubescence erect and rather long ............... Cressoniella Mitchell (in part)

-Mandible three-toothed; body smaller, about 7 $\mathrm{mm}$ in length; pubescence short, appressed Ptilosarus Mitchell

25(22). T6 nearly horizontal, carina either deeply emarginate, with dorsal surface markedly concave, or surface convex, preapical carina low, with only a small median notch Neochelynia Schrottky (in part)

- T6 vertical or nearly so, completely hidden in dorsal view of metasoma, carina low and entire or distinct, with small median emargination ............................................ 26

26(25). Preoccipital carina absent ... Chalepochile Gonzalez and Engel, n. subgen. -Preoccipital carina strong behind genal area ... 27 27(26). Carina of T6 strong, medially emarginate; disc of mesoscutum uniformly punctate, punctures separated by at most $1-2 \times$ a puncture width; clypeus largely asetose basally Rhyssomegachile Mitchell

-Carina of T6 weak and inconspicuous, often entire or weakly emarginate medially; disc of mesoscutum not uniformly punctate, with distinct impunctate areas, punctures separated by $\geq 2 \times$ a puncture width; clypeus 
more uniformly setose Austromegachile Mitchell (in part) 28(14). Metasoma about $2 \times$ as long as wide (carina of T6 usually emarginate medially; protarsus usually enlarged and pale; procoxa with spine and usually with red bristles) ................... 29

-Metasoma less than $2 \times$ as long as wide ........ 30 29(28). Pubescence of mesosoma and metasoma black except for broad white band on T3; mandible with small preapical inferior angle (Chile) Chrysosarus Mitchell [M. (C.) euzona Pérez] (in part) -Pubescence not forming above color pattern; mandible with large basal inferior projection Sayapis Titus 30(28). Carina of T6 entire or crenulate, median part most produced, with no trace of a median emargination 31

- Carina of T6 commonly crenulate, median part emarginate or sometimes irregular but not produced 33

31(30). Protarsus slender and simple, black or fuscous; apical flagellomere of antenna not at all dilated, fully $3 \times$ as long as broad; genitalia with apex of gonoforceps simple, usually bare and not dilated (primarily Nearctic) Argyropile Mitchell (in part)

- Protarsus usually dilated, ferruginous or yellowish; apical flagellomere of antenna usually dilated, about $2 \times$ as long as broad; genitalia with apex of gonoforceps enlarged and bifid, or if simple, then usually dilated and with conspicuous setae..... 32

32(31). S4 with small but distinct median tubercle on apical margin (large, robust species; Holarctic) ..............Xanthosarus Robertson (in part) -S4 without median apical tubercle, apical margin usually broadly membranous (Nearctic) Megachiloides Mitchell 33(30). Mandible four-toothed 34

-Mandible three-toothed 35

34(33). Protarsus frequently modified, pallid; genitalia with apex of gonoforceps enlarged and bifid, or if simple, usually dilated and with conspicuous setae (Holarctic) Xanthosarus Robertson (in part)
-Protarsus simple, dark-colored; genitalia with apex of gonoforceps simple, usually bare and not dilated (primarily Nearctic) . Argyropile Mitchell (in part) 35(33). Mandible with low median or preapical inferior angle in place of usual tooth (Neotropical) ...... Chrysosarus Mitchell (in part) -Mandible with strong inferior basal tooth ... 36 36(35). Protarsus broadly dilated, pale (Holarctic) Xanthosarus Robertson (in part) —Protarsus simple, black or nearly so ............... 37 37(36). Procoxal spine reduced to inconspicuous tubercle or absent (Holarctic) Megachile Latreille s.str. -Procoxal spine conspicuous, well developed ... 38 38(37). Morphological apical margin, not carina, of T6 without evident tooth (adventive) ...... Eutricharaea Thomson -Morphological apical margin of T6 with four small but distinct teeth (Nearctic) Litomegachile Mitchell

\section{DISCUSSION}

The main goal of this work was to address some taxonomic issues regarding two poorly known subgenera of leaf-cutter bees from South America. We circumscribed each subgenus, attempted to clarify species identities, provided fully illustrated species accounts, explored their phylogenetic relationships, described two new subgenera and several species as new to science, and developed keys that will assist researchers in their recognition. Despite these accomplishments, sex associations remain a main problem for these leaf-cutter bees, as only four of the 15 species treated in this work are known from both sexes (table 1). Thus, some nominal species might be the unknown sex of others and the taxonomic placement of some species might change in the future. For example, M. nigribarbis Vachal is known only from the male holotype, which we were unable to examine, and might be the male of $M$. durantae, $M$. reliqua, or $M$. moderata, or it could represent a legitimate species distinct from all of these. The Argentinean 
M. uncinata is also known only from the male and we assigned it to Zonomegachile based on the presence of the hypostomal projection (fig. 33E). However, this species is superficially quite different from the males of $M$. kalina and $M$. moderata, particularly in the shape of T6, S5-S8, and the male genitalia. Discovery of the female would certainly go a long way toward clarifying its placement among these species.

Our phylogenetic analysis supported the recognition of both Aporiochile and Chalepochile because species of both taxa did not cluster with either Rhyssomegachile or with Austromegachile, subgenera to which previous studies have assigned them. In addition, each subgenus has a unique combination of features that allow their easy recognition and distinction from related subgenera. However, Aporiochile and Chalepochile are known from the male sex only, branch support was low in our analysis (fig. 7), and some hypothesized relationships do not seem likely. For example, Aporiochile resulted as sister to Ptilosarus, while Zonomegachile was sister to Neochelynia. In fact, both sexes of Ptilosarus seem to us morphologically more similar to those of Neochelynia than to either Aporiochile or Zonomegachile. Michener (2007) suggested a close relationship of Zonomegachile to Chrysosarus and the phylogenetic analysis of Durante and Cabrera (2009) supported this idea, although these authors included male characters only for Zonomegachile and were not able to record many other characters for several species.

The position of Chalepochile in our analysis also seems unlikely. This subgenus seems more closely related to Austromegachile than to Rhyssomegachile. The males of Chalepochile have a distinctive metafemoral keirotrichial patch (fig. 5I), a feature also shared by Austromegachile but absent in Rhyssomegachile. However, this keirotrichial patch is present in some species of Chrysosarus, as well as in males of many other subgenera of Megachile s.l. (personal obs.). Undoubtedly, further studies aiming to associate sexes of these South American leaf-cutter bees will be critical to test their current taxonomic placements.

\section{ACKNOWLEDGMENTS}

We dedicate this contribution to our friend and colleague, Jerome G. Rozen, Jr., in celebration of both his 90th year and his retirement, and we look forward to his continued excellent work in melittology. We are greatly indebted to each of the curators listed by institution in the Material and Methods for the loan of specimens used in this work; to Amy R. Comfort and Kellie K. Magill Engel for their continuous love, support, and patience throughout this project; and Jennifer C. Thomas and Zachary H. Falin for their considerable assistance. We are thankful to Torsten Wappler and Daniela Matenaar for confirming the absence of Meyer's bees in the Hessisches Landesmuseum Darmstadt. We appreciate the comments of Jerome G. Rozen, Jr., and two anonymous reviewers for suggestions that improved this work, while Mary Knight kindly checked the formation of our new names and provided critical input and insights. The participation of V.H.G. was partly supported by National Science Foundation's REU program (DBI-1560389), while M.S.E. was partly supported by NSF DEB-1144162 and DBI-1057366. This is a contribution of the Division of Entomology, University of Kansas Natural History Museum.

\section{REFERENCES}

Baker, D.B., and M.S. Engel. 2006. A new subgenus of Megachile from Borneo with arolia (Hymenoptera: Megachilidae). American Museum Novitates 3505: $1-12$.

Cockerell, T.D.A. 1927. Megachilid bees from Bolivia collected by the Mulford Biological Expedition, 1921-22. Proceedings of the United States National Museum 71 (12): 1-22.

Dalla Torre, C.G., de [K.W., von]. 1896. Catalogus hymenopterorum hucusque descriptorum systematicus et synonymicus. Vol. 10: Apidae (Anthophila). Lipsiae [Leipzig]: Engelmann, viii + 643 pp.

Durante, S., and N. Cabrera. 2009. Cladistic analysis of Megachile (Chrysosarus) Mitchell and revalidation of Megachile (Dactylomegachile) Mitchell (Hymenoptera, Megachilidae). Zootaxa 2284: 48-62. 
Engel, M.S. 1999. Megachile glaesaria, the first megachilid bee fossil from amber (Hymenoptera: Megachilidae). American Museum Novitates 3276: 1-13.

Engel, M.S. 2001. A monograph of the Baltic amber bees and evolution of the Apoidea (Hymenoptera). Bulletin of the American Museum of Natural History 259: 1-192.

Engel, M.S. 2011. Systematic melittology: where to from here? Systematic Entomology 36 (1): 2-15.

Engel, M.S., and D.B. Baker. 2006. A remarkable new leaf-cutter bee from Thailand (Hymenoptera: Megachilidae). Beiträge zur Entomologie 56 (1): 69-74.

Engel, M.S., and V.H. Gonzalez. 2011. Alocanthedon, a new subgenus of Chalicodoma from Southeast Asia (Hymenoptera, Megachilidae). ZooKeys 101: 51-80.

Goloboff, P.A., J. Farris, and K. Nixon. 2003a. T.N.T.: tree analysis using new technology [program and documentation]. Online resource (http://www. zmuc.dk/public/phylogeny/tnt/).

Goloboff, P.A., et al. 2003b. Improvements to resampling measures of group support. Cladistics 19 (4): 324-332.

Goloboff, P.A., J.S. Farris, and K.C. Nixon. 2008. TNT, a free program for phylogenetic analysis. Cladistics 24 (5): 774-786.

Gonzalez, V.H. 2008. Phylogeny and classification of the bee tribe Megachilini (Hymenoptera: Apoidea, Megachilidae), with emphasis on the genus Megachile. Ph.D. dissertation, University of Kansas, Lawrence, $274 \mathrm{pp}$.

Gonzalez, V.H. 2013. Taxonomic comments on Megachile subgenus Chrysosarus (Hymenoptera: Megachilidae). Journal of Melittology 5: 1-6.

Gonzalez, V.H., and M.S. Engel. 2012. African and Southeast Asian Chalicodoma (Hymenoptera: Megachilidae): new subgenus, new species, and notes on the composition of Pseudomegachile and Largella. Annales Zoologici 62 (4): 599-617.

Gonzalez, V.H., M.S. Engel, and I.A. Hinojosa-Díaz. 2010. A new species of Megachile from Pakistan, with taxonomic notes on the subgenus Eutricharaea (Hymenoptera: Megachilidae). Journal of the Kansas Entomological Society 83 (1): 58-67.

Gonzalez, V.H., T. Griswold, and M.S. Engel. 2013. Obtaining a better taxonomic understanding of native bees: where do we start? Systematic Entomology 38 (4): 645-653.

Hirsch, G.C. 1928. Index biologorum: investigatores, laboratoria periodica. Berlin: Springer, 546 pp.

ICZN [International Commission on Zoological Nomenclature]. 1999. International code of zoo- logical nomenclature [4th edition]. London: International Trust for Zoological Nomenclature, xxix + 306 pp.

Kim, J.-Y. 1992. Nest dimensions of two leaf-cutter bees (Hymenoptera: Megachilidae). Annals of the Entomological Society of America 85 (1): 85-90.

Koch, U. 1999. Die Schwebfliegensammlung (Diptera, Syrphidae) des Hessischen Landesmuseums Darmstadt. Ein Beitrag zur Syrphiden-fauna Südhessens. Hessische Faunistische Briefe 18 (2-3): 27-37.

Michener, C.D. 1962. Observations on the classification of the bees commonly placed in the genus Megachile (Hymenoptera: Apoidea). Journal of the New York Entomological Society 70 (1): 17-29.

Michener, C.D. 1965. A classification of the bees of the Australian and South Pacific regions. Bulletin of the American Museum of Natural History 130: 1-362.

Michener, C.D. 2007. The bees of the world, 2nd ed. Baltimore: Johns Hopkins University Press, xvi + [i] + 953 pp., +20 pls.

Michener, C.D., and A. Fraser. 1978. A comparative anatomical study of mandibular structure in bees (Hymenoptera: Apoidea). University of Kansas Science Bulletin 51 (14): 463-482.

Mitchell, T.B. 1930. A contribution to the knowledge of neotropical Megachile with descriptions of new species (Hymenoptera: Megachilidae). Transactions of the American Entomological Society 56 (3): 155$305,+5$ pls. [pls. $\mathrm{x}-\mathrm{xiv}$ ]

Mitchell, T.B. 1933. A revision of the genus Megachile in the Nearctic region. Part I. Classification and descriptions of new species (Hymenoptera: Megachilidae). Transactions of the American Entomological Society 59 (4): 295-361, +2 pls. [pls. xx-xxi]

Mitchell, T.B. 1943. On the classification of neotropical Megachile (Hymenoptera: Megachilidae). Annals of the Entomological Society of America 36 (4): 656671.

Mitchell, T.B. 1980. A generic revision of the megachiline bees of the western hemisphere. Raleigh: North Carolina State University, [ii] + 95 pp.

Moure, J.S. 1948. Notas sobre algumas abelhas de Tacanas, Tucumán, Argentina (Hymenopt. Apoidea). Revista de Entomologia 19 (1-2): 313-346.

Moure, J.S., G.A.R. Melo, and A. DalMolin. 2007. Megachilini Latreille, 1802. In J.S. Moure, D. Urban, and G.A.R. Melo (editors), Catalogue of bees (Hymenoptera, Apoidea) in the Neotropical region: 917-1001. Curitiba: Sociedade Brasileira de Entomologia, xiv + 1058 pp. [updated online (http://www.moure.cria. org.br/catalogue), accessed 31 July 2018] 
Nixon, K.C. 1999. WinClada, (beta) version 0.9 [program and documentation]. Ithaca, NY: Published by the author.

Pasteels, J.J. 1965. Revision des Megachilidae (Hymenoptera Apoidea) de l'Afrique noire. I. Les genres Creightoniella [sic], Chalicodoma et Megachile (s. str.). Koninklijk Museum voor Midden-Afrika, Tervuren, België, Annalen, Reeks In- $8^{\circ}$, Zoologische Wetenschappen 137: ix + 1-579.

Praz, C.J. 2017. Subgeneric classification and biology of the leafcutter and dauber bees (genus Megachile Latreille) of the western Palearctic (Hymenoptera, Apoidea, Megachilidae). Journal of Hymenoptera Research 55: 1-54.

Rasmussen, C., B.R. Garcete-Barrett, and R.B. Gonçalves. 2009. Curt Schrottky (1874-1937): South American entomology at the beginning of the 20th century (Hymenoptera, Lepidoptera, Diptera). Zootaxa 2282: 1-50.

Raw, A. 2002. New combinations and synonymies of leafcutter and mason bees of the Americas (Megachile, Hymenoptera, Megachilidae). Zootaxa 71: 1-43.

Raw, A. 2006. A new subgenus and three new species of leafcutter bees, Megachile (Austrosarus) (Hymenoptera, Megachilidae) from central Brazil. Zootaxa 1228: 25-34.

Schlindwein, C. 1998. Frequent oligolecty characterizing a diverse bee-plant community in a xerophytic bushland of subtropical Brazil. Studies on Neotropical Fauna and Environment 33 (1): 46-59.

Schrottky, C. 1908. Nuevos himenópteros. Anales de la Sociedad Científica Argentina 65 (4): 225-239.

Schrottky, C. 1913. As espécies Brazileiras do genero Megachile supplemento ao "Ensaio sobre as abelhas solitárias do Brasil” (Rev. Mus. Paul. vol. V, p. 330-613, 1902). Revista do Museu Paulista 9 (7): 134-223. [article numbers 7-10, of which Schrottky's was no. 7, were published December 1913, while the entire volume, including all 22 articles, was released September 1914]

Shorthouse, D.P. 2010. SimpleMappr, an online tool to produce publication-quality point maps [program and documentation]. Online resource (http://www. simplemappr.net).
Silveira, F.A., G.A.R. Melo, and E.A.B. Almeida. 2002. Abelhas brasileiras: sistemática e identificação. Belo Horizonte: Editora IDMAR, 253 pp.

Smith, F. 1853. Catalogue of the hymenopterous insects in the collection of the British Museum. Part 1. Andrenidae and Apidae. London: British Museum, [i] + 198 pp., +pls. i-vi.

Smith, F. 1879. Descriptions of new species of Hymenoptera in the collection of the British Museum. London: British Museum, xxi + 240 pp.

Tischendorf, S., U. Frommer, H.-J. Flügel, K.-H. Schmalz, and W.H.O. Dorow. 2009. Kommentierte Rote Liste der Bienen Hessens - Artenliste, Verbreitung, Gefährdung [1. Fassung]. Wiesbaden: Hessischen Ministeriums für Umwelt, Energie, Landwirtschaft und Verbraucherschutz, 152 pp.

Torretta, J.P., S.P. Durante, and A.M. Basilio. 2014. Nesting ecology of Megachile (Chrysosarus) catamarcensis Schrottky (Hymenoptera: Megachilidae), a Prosopis-specialist bee. Journal of Apicultural Research 53 (5): 590-598.

Trunz, V., L. Packer, J. Vieu, N. Arrigo, and C.J. Praz. 2016. Comprehensive phylogeny, biogeography and new classification of the diverse bee tribe Megachilini: can we use DNA barcodes in phylogenies of large genera? Molecular Phylogenetics and Evolution 103: 245-259.

Vachal, J. 1909. Espèces nouvelles ou litigieuses d'Apidae du haut Bassin du Parana et des régions contiguës et délimitation d'une nouvelle sous-famille Diphaglossinae (Hym.). Revue d'Entomologie 28 (1-2): 5-70.

Wedmann, S., T. Wappler, and M.S. Engel. 2009. Direct and indirect fossil records of megachilid bees from the Paleogene of central Europe (Hymenoptera: Megachilidae). Naturwissenschaften 96 (6): 703712.

Zillikens, A., and J. Steiner. 2004. Nest architecture, life cycle and cleptoparasite of the neotropical leaf-cutting bee Megachile (Chrysosarus) pseudanthidioides Moure (Hymenoptera: Megachilidae). Journal of the Kansas Entomological Society 77 (3): 193-202. 





\title{
Scientific Publications of the American Museum of Natural History
}

AMERICAN MUSEUM NOVITATES

BULLETIN OF THE AMERICAN Museum of NATURAL History

anthropological Papers of the american museum of Natural history

\author{
Publications Committee \\ ROBERT S. VOSS, CHAIR \\ BOARD OF EDITORS \\ Jin Meng, Paleontology \\ LORENZO PRENDINI, INVERTEBRATE ZOOLOGY \\ ROBERT S. VOSS, VerTEBRATE ZOOLOGY \\ Peter M. Whiteley, Anthropology \\ MANAGING EDITOR \\ MARY KNIGHT
}

Submission procedures can be found at http://research.amnh.org/scipubs

All issues of Novitates and Bulletin are available on the web (http://digitallibrary.amnh.

org/dspace). Order printed copies on the web from:

http://shop.amnh.org/a701/shop-by-category/books/scientific-publications.html

or via standard mail from:

American Museum of Natural History — Scientific Publications

Central Park West at 79th Street

New York, NY 10024

(0) This paper meets the requirements of ANSI/NISO Z39.48-1992 (permanence of paper).

On the cover: A male paratype of Megachile (ZonoMEGACHILE) KALINA, NEW SPECIES, FROM FRENCH GUIANA, PRESERVED GRASPING THE BROOD CELL, MADE OF CUT LEAVES, FROM WHICH IT EMERGED. 